\title{
تصور مقترح لتفعيل أساليب تحديد الاحتياجات التدريبية لدى معلمي التعليم الثانوي بمنطقة الرياض- دراسة ميدانية
}

$$
\begin{aligned}
& \text { إعـداد } \\
& \text { د. هاني محمد يونس موسىى } \\
& \text { أستاذ أصول التربية المساعد- قسم أصول التربية } \\
& \text { كلية التربية - جامعة بنها }
\end{aligned}
$$

مجلة الدراسات التربوية والانسانية ـ كلية التربية ـ جامعة دمنهور

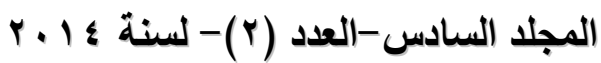


تصور مقترح لتفعيل أساليب تحديد الاحتياجات التدريبية د. هاني محمد يونس موسى

- 
تصور مقترح لتفعيل أساليب تحديد الاحتياجات التدريبية لاى معلمي التعليم

\section{الثانوي بمنطقة الرياض- دراسة ميدانية}

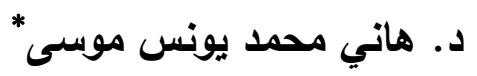

\section{مقدمة:}

خـالد العقدين الماضـيين حـدثت تطـورات كبيـرة للمجتمـع العـالمي في شـتى

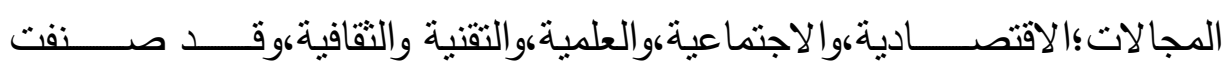

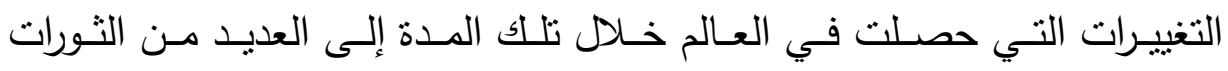

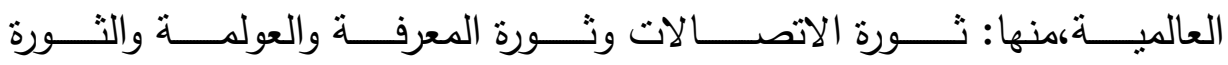

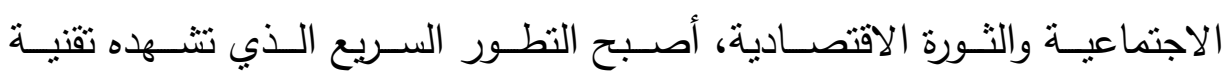

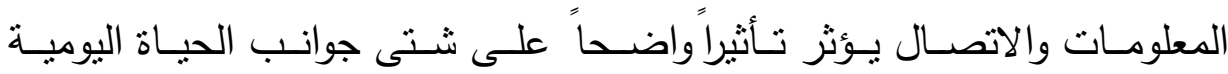

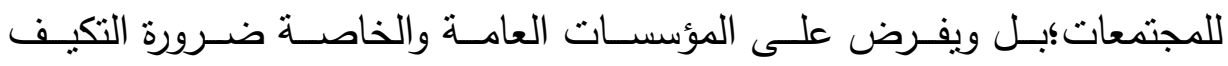

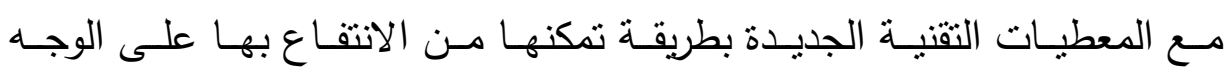
الأكمل، وتحد بقدر الإمكان من الأخطار التي تكمن فيها.

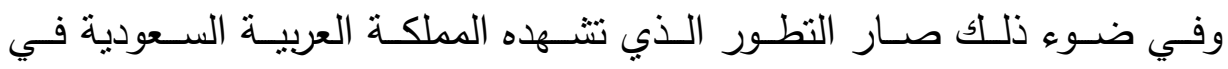

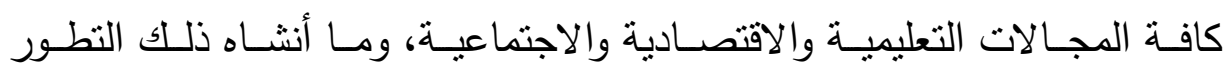

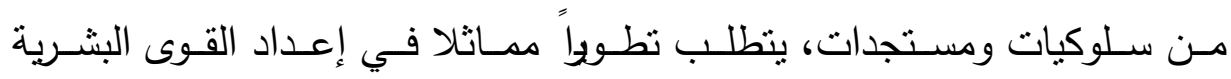

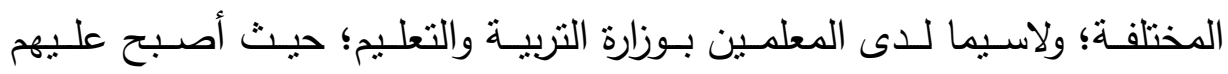

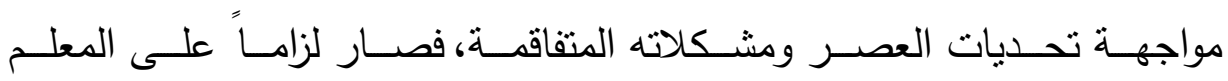
المحافظــة على مسـتوى متجـدد، وصـار النظــام التربـوي في المملكـة العربيـة

\footnotetext{
أستاذ أصول التربية المساعد بقسم أصول التربية ـ كلية التربية- جامعة * إبن.بnany.mossoua@fedu.bu.edu.eg
} 
السـعودية - منــذ بــدايات القـرن العشـرين - يـــرك أهميـة تــدريب المعلمـين،

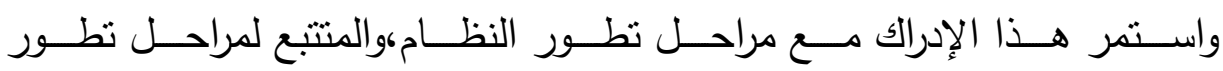

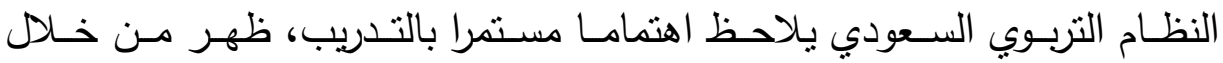
خطط التنديب التي نفذت عبر السنوات السابقة . وكان للتقدم المعرفي الهائل الذي تميز به العصر الحالي- والذي يتسم بالتغير الكمي والكيفي السريع في المعرفة العلمية وتطبيقاتها؛ خاصة ما يحدث في مجال التربية من تطور نتيجة للأبحاث العلمية المستمرة، واستخدام التقنيات الحديثةدوره الواضح في حرص المعلم على مستوى متجدد من المعلومات والمهارات

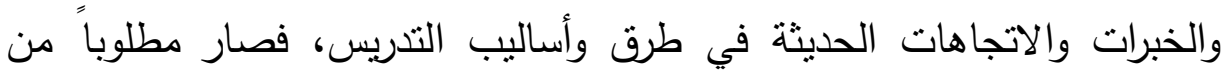
المعلم أن يكون في مرحلة تدريب مستمرة خلال حياته المهنية؛حتى يمكنه ملاحقة كل جديد في مجال عمله، ومن ثم الارتقاء بمستوى أدائه.

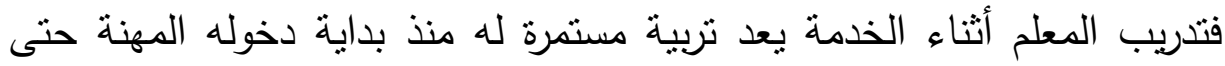

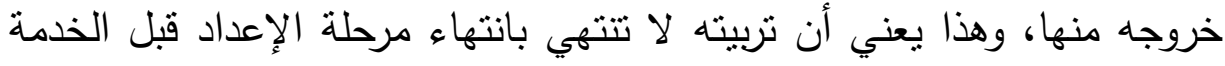

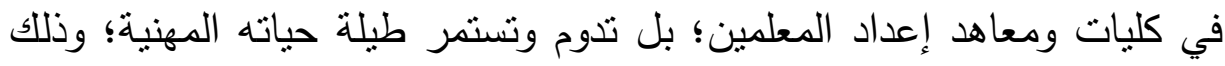
حتى يمكن الإلمام بكل مستحدث في مجال التربية وعلم النفس، والمجال الأكاديمي، وحتى يمكن إتقان مهارات استخدام مبتكرات تكنولوجيا التعليم من مواد تعليمية، وطرق تدريس جديدة، وللوقوف على ما بطرأ من تغيرات وتطورات

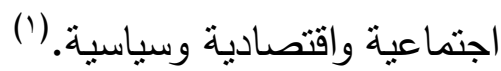
وجاء تطور التدريب في المملكة العربية السعودية مواكبا للنطورات العالمية،حيث استخدم النظـام التعليمي إجراءات مختلفة،لعل أهمها:إيفاد المعلمين في بعثات فئات خارجية، والدراسـات العليا، والإيفاد الداخلي، وتدريب المعلمين محليا في مراكز التدريب التربوي والجامعات المحلية؛ التي تتفذ برامج معتمدة من قبل وزارة الخدمة

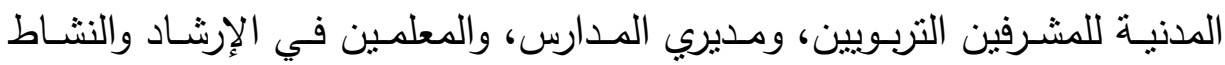

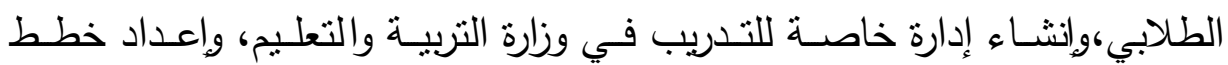


تدريب سنوية متلاحقة، كما اهتم مشروع الملك عبداله لتطوبر التعليم بالتتميـة المهنية للمعلمين، وذللك من خلال ما تبناه في ميزانيته وطموحاته، حيث قام بيناء

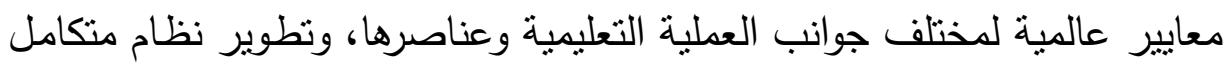
لتقويم التعليم وقياس مستوى الجودة، واعادة تأهيل المعلمين والمعلمات، وتهيائتهر وناهيه

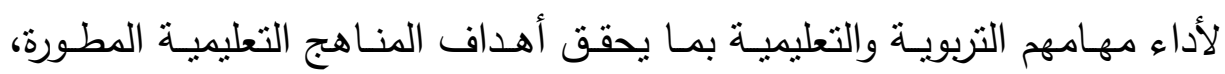

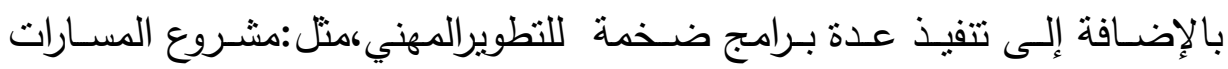

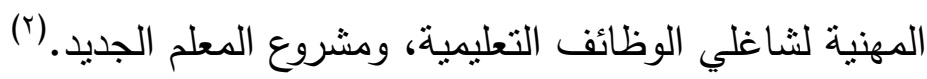
وقد أكدت سياسة التعليم في المملكة العربية السعودية على أهمية التتمية المهنية؛ فقد نصت على ذلك في عدد من موادها ، وهي على النحو التالي: مثل المادة

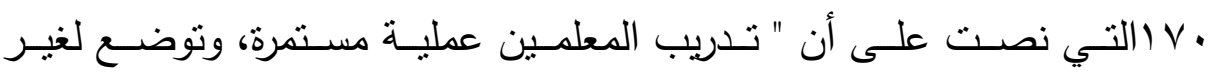

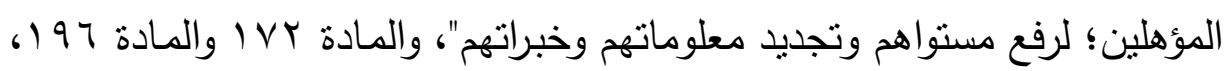

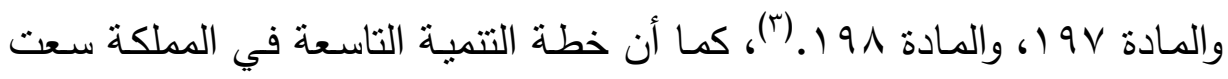

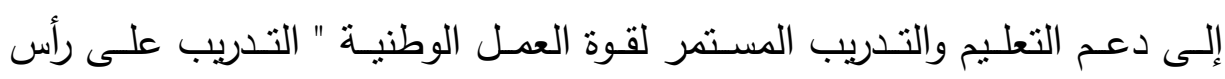

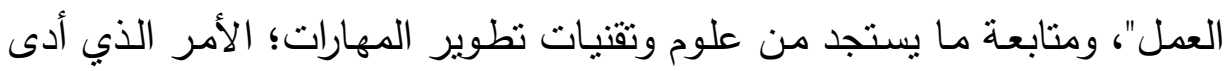

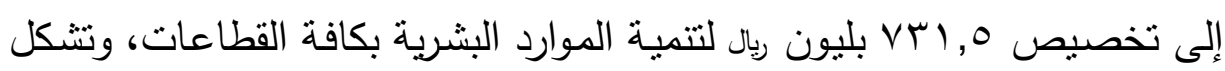

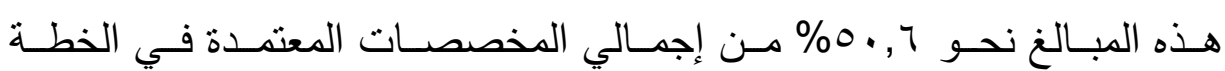

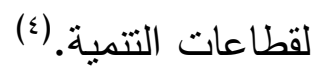
وقـد أوكـل لإدارة التـدريب بـوزارة التربيـة والتعليم مسـؤلية تتفيـذ سياسـة الـوزارة التدريبية المتعلقة بتطوير الكفايات التربوية والمهنية للهيئة التعليمية والفنية بالوزارة

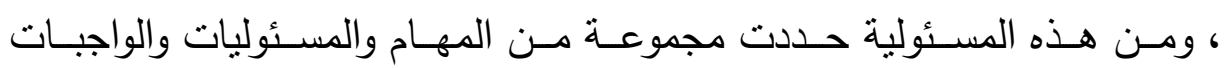
والأهداف من أجل تفعليها. ويأتي هذا الاهتمام بالتدريب أثناء الخدمة على اعتبار أنسه الأسـاس الذي يحقق

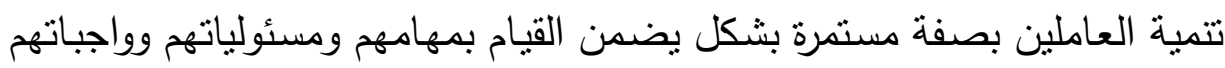

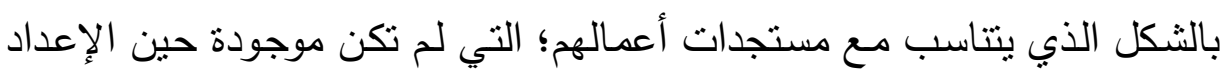


قبل الخدمـة، فالتـدريب يقدم معرفـة جديدة، ويضيف معلومـات متتوعـة، ويعطي مهارات وقدرات ويؤثز على الاتجاهات، ويعدل الأفكار ،ويغير السلوك، ويطور العادات والأساليب. - مهارات ولنات ومن الحقائق التي لا جدال فيها أن التدريب لا يؤدي هذا الدور بفعالية إلا إذا تم

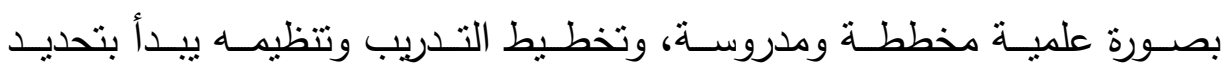
الاحتياجـات التدريبيـة، وينتهي بـالتقييم الذي يحدد، والـى أي مدى تمدت مقابلـة الاحتياجات المحددة للمتدربين.(0) ويمكن القول: إن تحديد الاحتياجات التدربيية يمثل الخطوة الأولى والرئيسة في

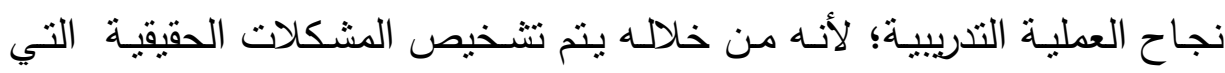

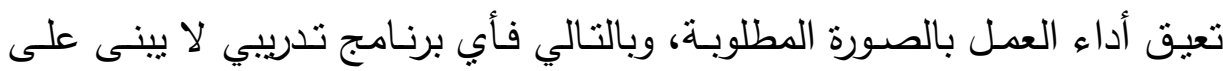

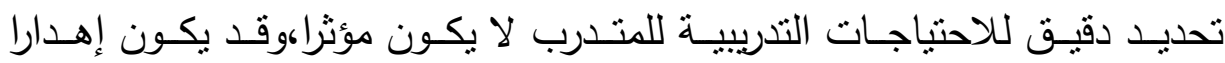
للإمكانات البشرية والمادية.(1)

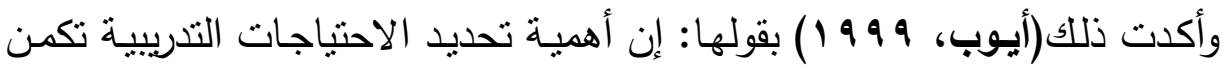

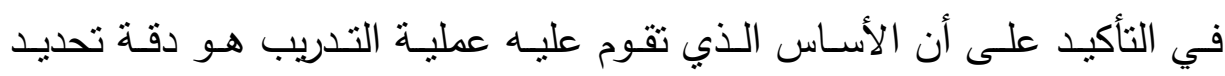
الاحتياجات التدربيية، وبالتالي تصبح هذه العملية أساسا ونقطة انطلاق لتصميم البرامج التنريبية بعد تحديد هذه الاحتياجات،ومن خلال مقارنة الكفايات والمهارات المتاحة في المؤسسة،يمكن تحديد النقص المطلوب تعويضـه من خلال التدريب،

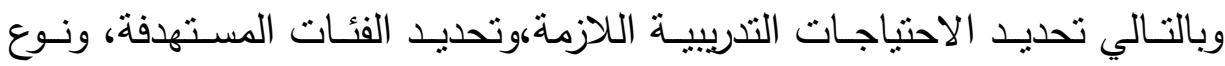

$$
\text { التدريب اللازم لها. (v) }
$$

وتحظى المرحلة الثانويـة بشكل عام بخصوصية بين المراحل التعليمية الأخرى

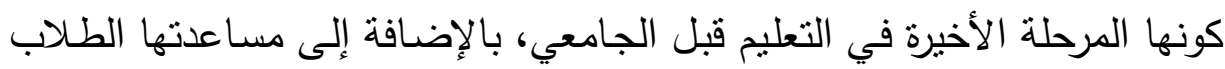

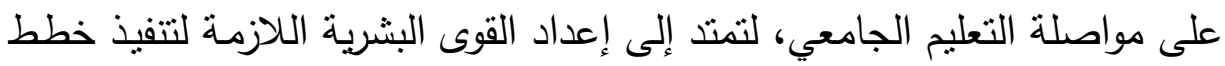
التحول الاجتماعي والاقتصادي، والوفاء بمتطلبات التتمية. 
وقد احتل موضوع تحديد الاحتياجات التنريبية للمعلمين اهتمـام عدد كبير من البـاحثين والدارسـين مـن خـلال استقصــاء آراء المعلمـين والمـديرين والمشـرفين

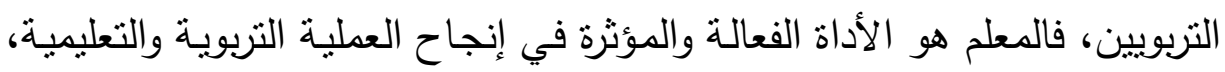

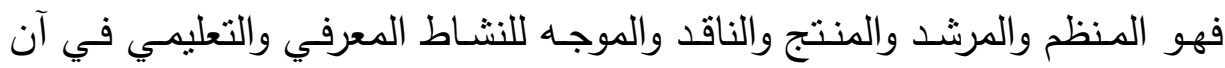

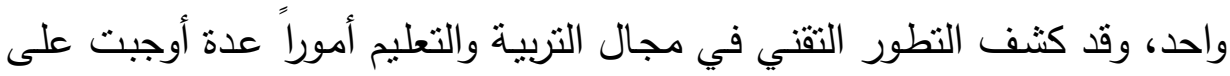

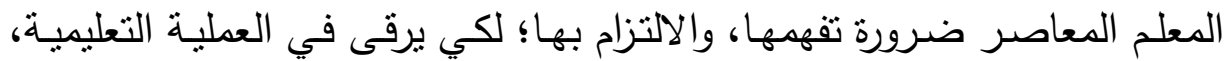
ولكي يحقق تدريب المعلم أثناء الخدمة أهدافه فلابد من " تلبية الحاجات التدريبية للمعلمين، حيث إن التدريب المستمر وسيلة لإعادة بناء وتجديد خبرات ومهارات وكفاءات المعلمين في ضوء ما يستجد من مستحدثات، وأن يكون التدريب حسب

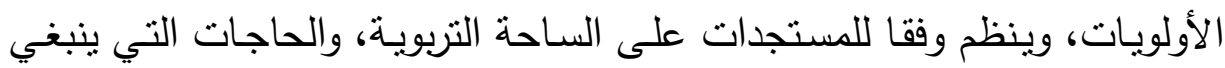

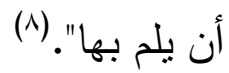
وتتككل عملية التحديد الدقيق للاحتياجات التدريبية أحد المدخلات الأساسية التي تضمن تحديد أهداف واضحة ومحددة للتدريب، كما أن تحديد الاحتياجات يوضح

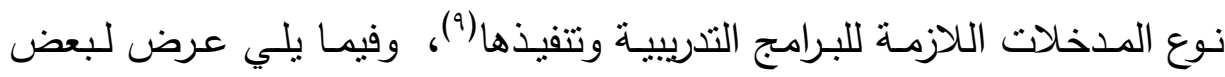
الدراسات المتصلة بموضوع البحث: فعن تقدير الاحتياجات التدريبية لمديري المدارس الثانويـة بالأردن جاءت دراسـة

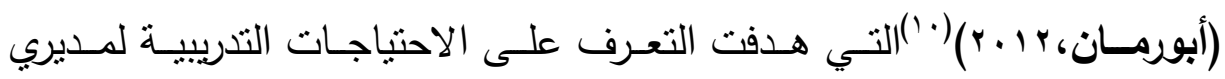

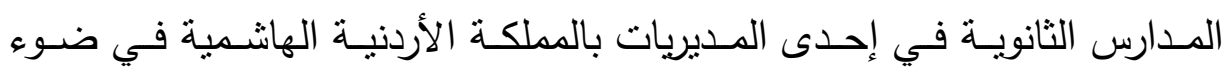
التطوير التربوي، وانتهت إلى عدة توصيات، منها:ضـرورة عقد دورات تدريبيـة

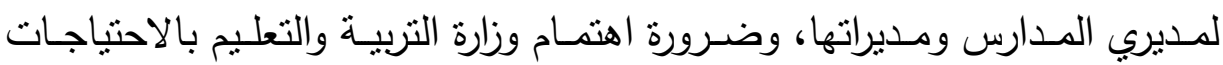
التدريبية للمديرينهواتثراكهم في اتخاذ القرار لتحديد مضامين البرامج التدريبية التي بـي تقدم لهم، مع ضرورة التسيق بين وزارة التربية والتعليم وبين الجامعات الأردنية؛ لتضمين المواد الدراسية المقدمة لطلاب كليات التربية المهارات والمعارف المنبتقة من الاحتياجات التنريبية للمعلمين في الميدان التربوي. 


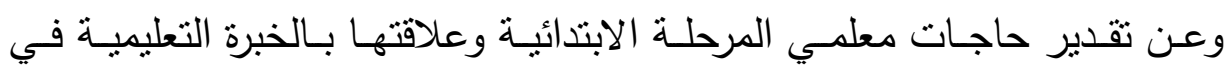
الصفوف الابتدائية، ركزت دراسة تروت(Trout,1989) (') على تحليل الحاجات المقدرة لمعلمي المدارس الحكومية في صفوف المرحلة الابتدائية، وعلاقة كل من المؤهل، وسنوات الخبرة في تقدير الاحتياجات، وكان من أهم نتائجها: إن هذه وعنه

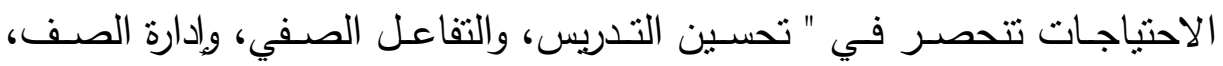
واختيار المواد التعليمية". وتوصل( خطاب، ؟99 1) (ז') في دراسة قام بها حول تحديد الاحتياجات التدريبية للمعلمين في دولـة الإمـارات العربيـة المتحدة إلى ضـرورة التركيز على كفايـات تتعلق بمواكبـة المستجدات في المـادة العلميـة، وإتقان مضـمون المـادة العلميـة، وتعديل السلوك، وتحديد الأساليب والأنشطة، والوسائل المناسبة، واستثارة دافعية التلاميذ.

وعن الاحتياجات التدريبيـة لمعلمي العلوم في المرحلتين الإعداديـة والثانويـة في

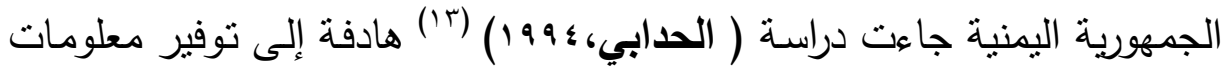
عن الاحتياجـات التدريبيـة؛ للمسـاهمة في تصميم برنـامج تدريب معلمي العلوم

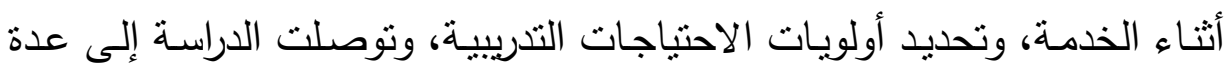

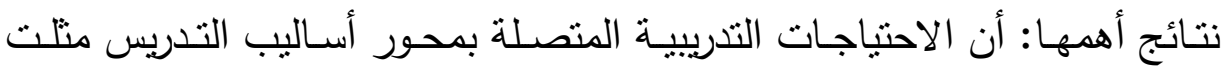

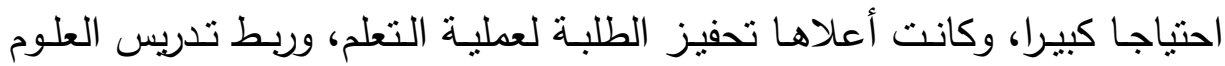
بتتمية التفكير العلمي. وهـدفت دراسـة سـيجر (Seger,1996) (£ (') التعـرف علـى الاحتياجـات التدريبيـة لمعلمي المرحلة المتوسطة من وجهة نظر المعلمين،ومديري المدارس في إحدى

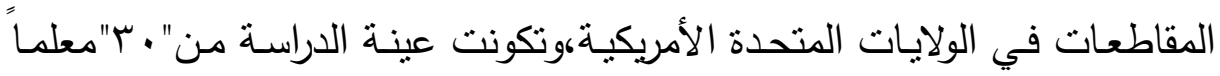

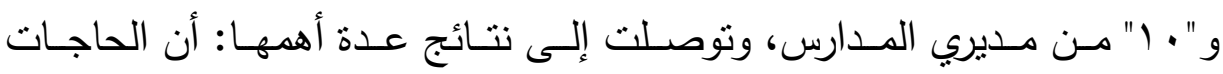
التدريبية تتمثل في بناء برنامج خاص لمعلمي المدارس المتوسطة مبنى على ولى 
جوانب وخبرات عمليـة للمستوى المتوسط، وعقد دورات تدريبيـة تتعلق بأسـاليب التعليم.

وركزت دراسـة (الغنيمـات، ب . . ب)(10)على تحديد الاحتباجات التدريبية لمعلمي

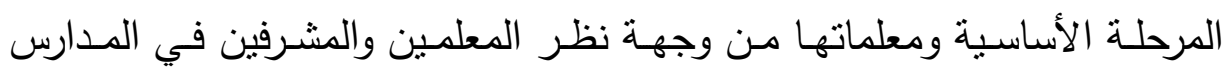

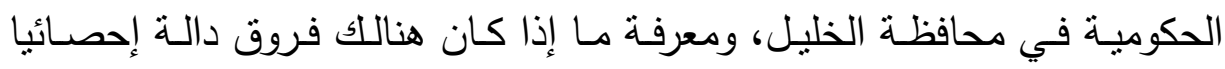

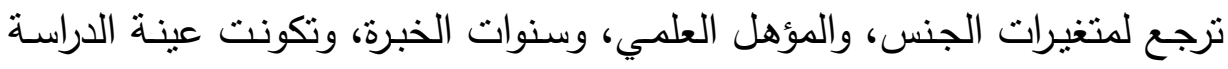

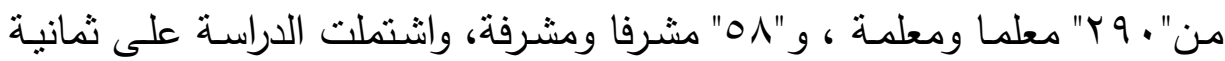

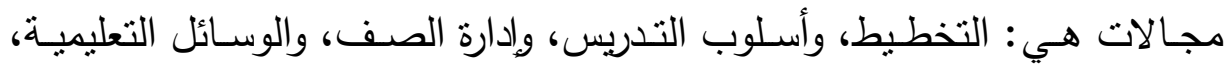

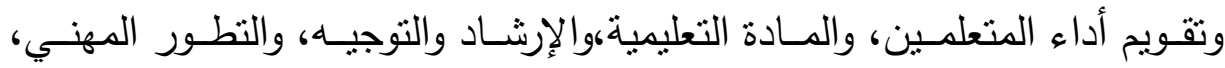

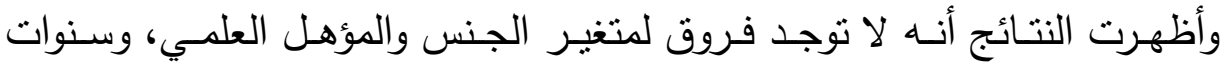

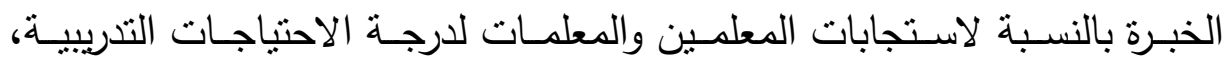
وكذلك المشرفين والمشرفات.

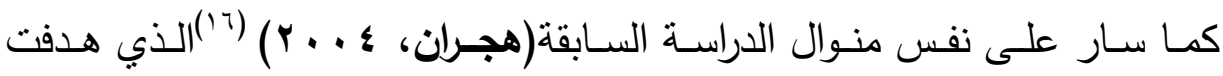
دراسته تحديد الاحتياجات التدريبية لمعلمي التعليم العام كما يراها المتخصصون، والتوصل إلى بناء برنامج تدريبي مقترح لهم في ضوء حاجتهم التدريبية من وجهة نظر القادة التربويين والمختصين والمشرفين التربويين بالمملكة العربية السعودية،

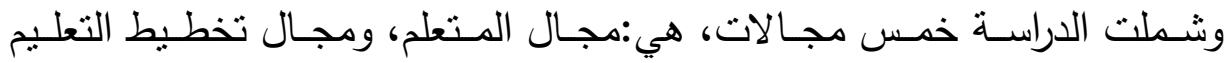
وتتفيذه، ومجـال الاتصـال والتفاعل، ومجـال تقنيـات التعليم ووسـائله، ومجــال التقويم، وتوصـلت الدراسـة إلـى عـدة نتـائج، منها:بنـاء برنـامج تـدريبي لتهيئة

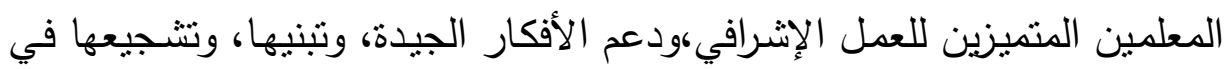

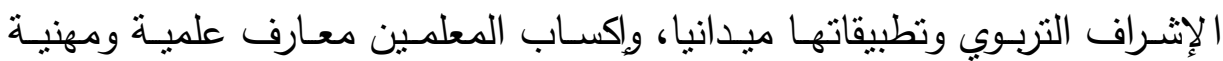
جديـدة في مجـال تخصصـاتهم، والتعـرف على التقنيـات الحديثـة في التـدريس والإفادة منها. 


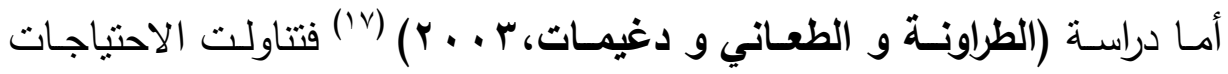

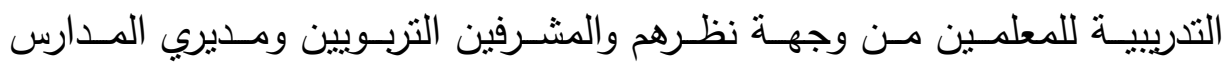

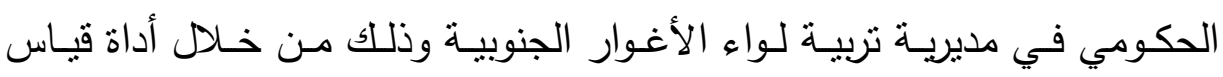
تكونت من "§؟" فقرة من نوع الاختبار من متعدد غطت أربع مجالات، وأنشارت

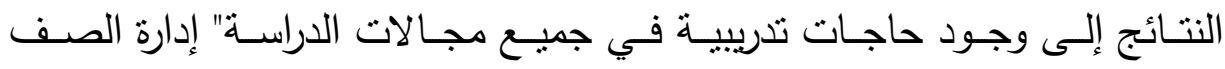
والتعامل مـع التلاميذ، والأساليب والأنشطة والتخطيط للتعليم والتقويم"، كما تبين

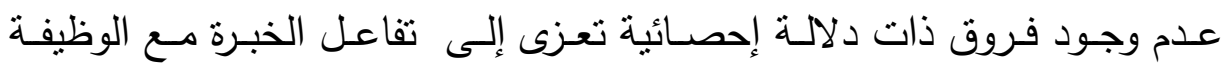
والمؤهل.

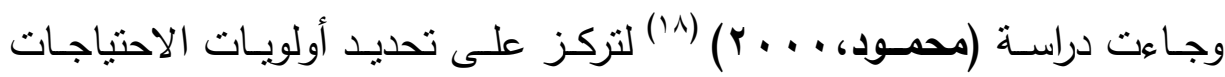

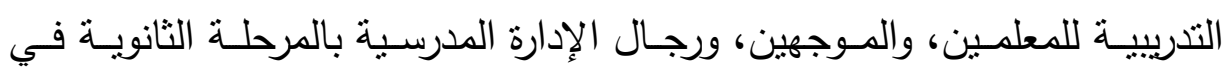
مجال توظيف تكنولوجيا التعليم في العملية التعليمية في مصر ، وانتهت الدراسـة

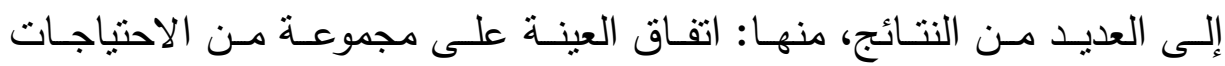

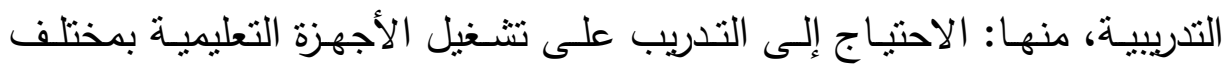
أنواعها. وعن واقـع التـدريب أثنـاء الخدمـة لمعلمي التربيـة الرياضية في مملكـة البحرين

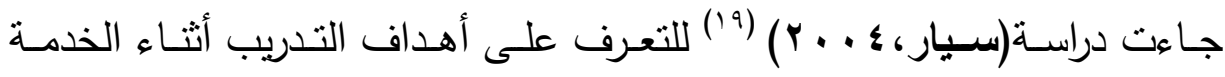
لمعلمي التربية الرياضية، وكذلك احتياجات المعلمين إلى البرامج التدريبية،وأنواع

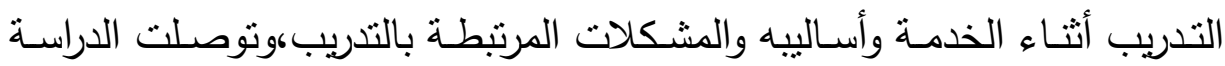
إلى عدة نتائج أهمها: أن التدريب أنثاء الخدمـة هام للمدرسـة في زيادة الخبرات والارتقاء بمستوى أداء المعلم، وحول احتياجات المعلمين إلى مواد دراسية أكدت الدراسة المواد النظرية والعملية في علوم التربية البدنية والرياضية. مشكلة الدراسة: على الرغم من كثرة ما كتب ونشر عن أهمية مرحلة تحديد الاحتياجات التدريبية

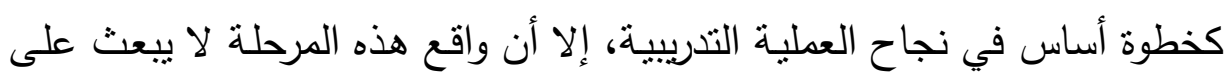


التفاؤل، فالبعض من المعنيين بالتدريب لا يدرك أهميـة هذه الخطوة ودورهـا في

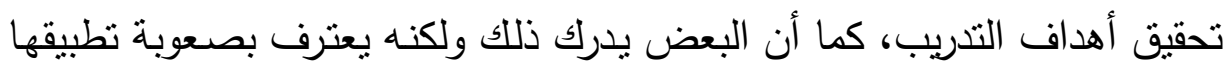

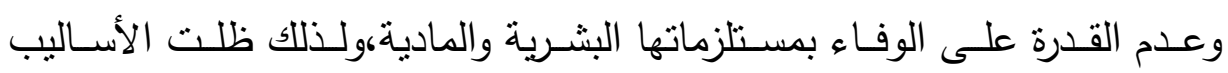

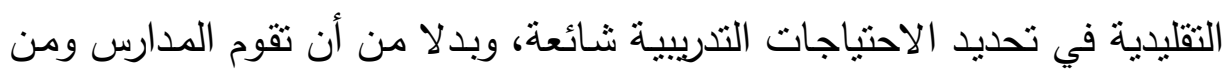
ثم إدارات وزارة التربية والتعليم بالتعاون مع إدارة التدريب والتطوير المهني(المعنية

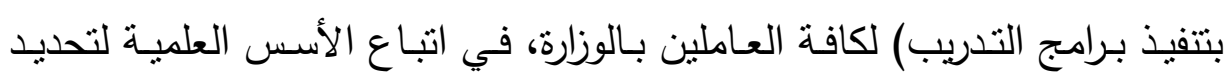
احتياجاتها؛ فإنها لجأت إلى أسهل الطرق وأقلها كفاءة وفاعلية، فهناك من يكتفي بمراجعة خطـة التدريب للعام الماضـي والحالي، فيجري بعض التعديلات عليها

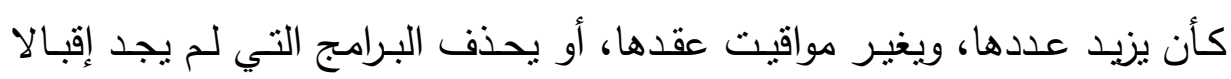

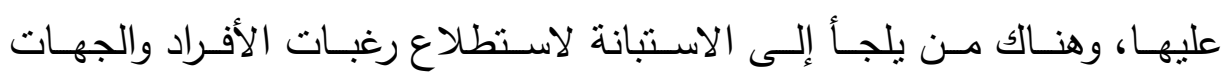

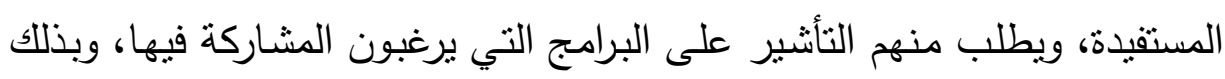

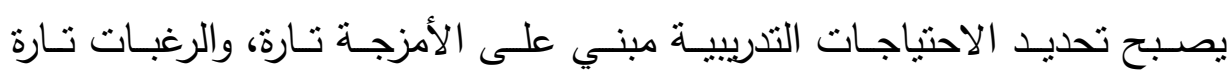

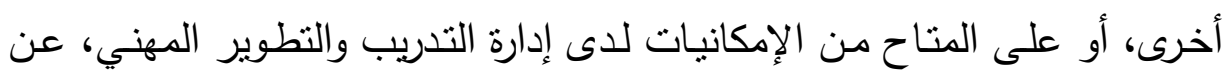

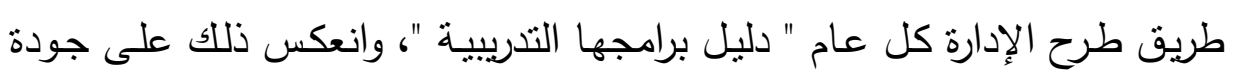
البرامج التدربيية ، وشكوى بعض العاملين بأن التحاقهم في البرنامج غير مبنِ على احتباجاتهم التذربيية الواقعية. فالتوصيف الوظيفي لإدارة التدريب يتضدن قيامها بالدراسات التشخيصية والمسوح

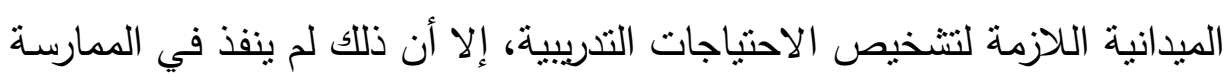

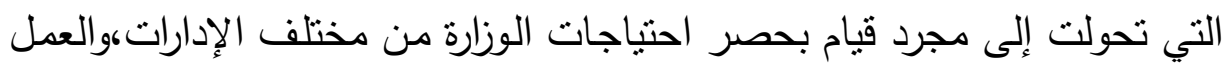

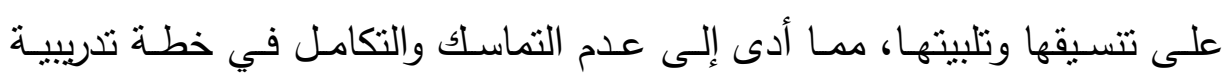
ضمن إستراتيجية واضحة للتتمية المهنية المستدامة للعاملين بوزارة التربية والتعليم في المملكة العربية السعودية . ومن خلال عمل الباحث في مركز التدريب وخدمة المجتمع بجامعة الملك سعود بالرياض واحتكاكه بكثير من المعلمين ومديري المدارس وإخصائي مصادر التعلم 
ورواد النشاط، وكل هؤلاء معلمون تدربوا بالمركز لفترات كبيرة، وحضروا العديد

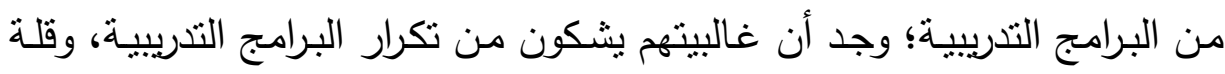
الإفادة منها؛ نظرا لأنها لا تلبي احتناجاتهم التدربيية الفعلية.

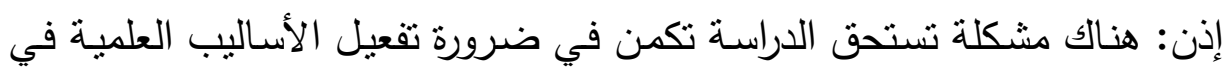

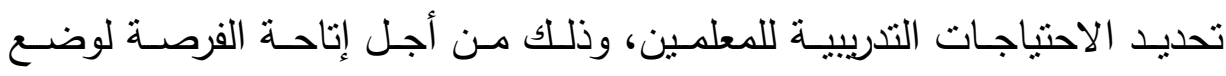

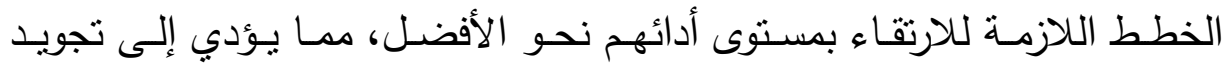
التعليم، ورفع الكفاءة الإنتاجية للنظام التربوي. ويمكن صياغة مشكلة الدراسة في السؤال الرئيس التالي:

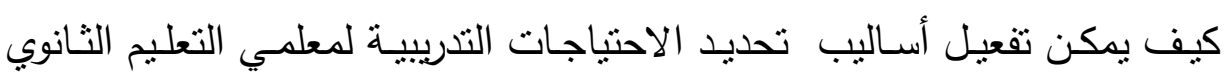
بمنطقة الرياض في المملكة العربية السعودية؟ ويتفرع من هذا السؤال التساؤلات الفرعية التالية:

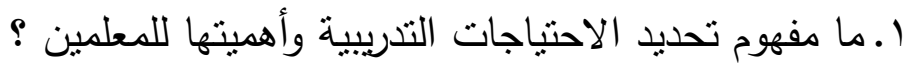
r. ما الأساليب العلمية المستخدمة في تحديد الاحتباجات التدريبية للمعلمين؟ r. هل تختلف إجراءات و أسـاليب تحديد الاحتباجـات التدريبيـة لمعلمي التعليم الثانوي بمنطقة الريـاض في المملكـة العربيـة السـودية بـاختلاف المؤهـل

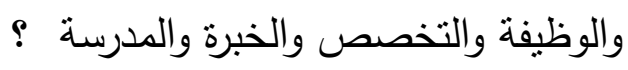

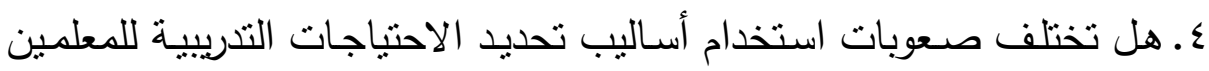
باختلاف المؤهل والوظيفة والتخصص والخبرة والمدرسة؟

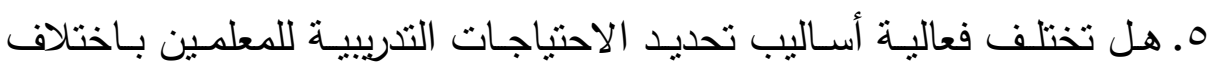
المؤهل والوظيفة والتخصص والخبرة والمدرسة؟

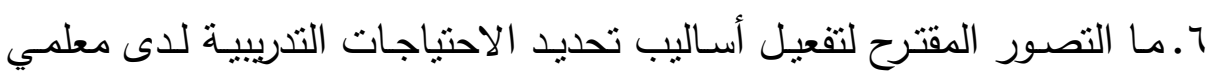
التعليم الثانوي - بنين بمنطقة الرياض ؟ أهداف الاراسة: من المتوقع بعد انتهاء الدراسة الحالية تحقيق الأهداف التالية : 
ا ـ التعرف على مفهوم الاحتباجات التدرييية وعناصرها وأنواعها. r. التعرف على الأساليب العلمية في تحديد الاحتباجات التدربيية للمعلمين. r. تحديد الصعوبات التي تعيق استخدام أساليب تحديد الاحتياجات التدريبية للمعلمين.

ع. الكثف عن مدى تفعيل أساليب تحديد الاحتباجات التدريبية للمعلمين من وجهة نظر عينة البحث. 0. التعرف على أهم الفوائد المترتبة على استخدام أساليب تحديد الاحنياجات التدريبية من وجهة نظر أفراد عينة البحث.

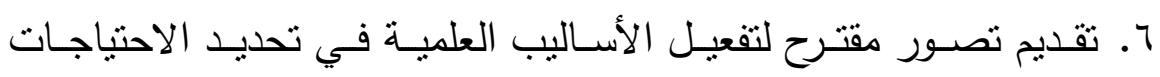

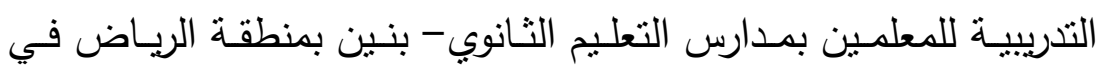
المملكة العربية السعودية.

أهمبة الدراسة

ا ـ تعد الاحتياجات التدريبية هي نقطة البدء التي تتطلق منها عملية تخطيط

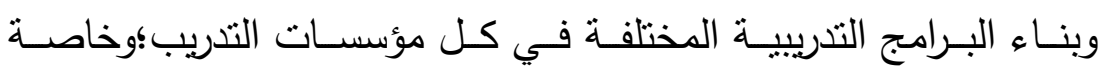

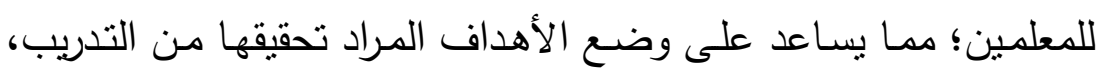
بل وتحديد متطلبات التدريب المستقبلية. r. إن تحديد الاحتياجات التدريبية يساعد في إحداث التغييرات المطلوبة لاى بلى

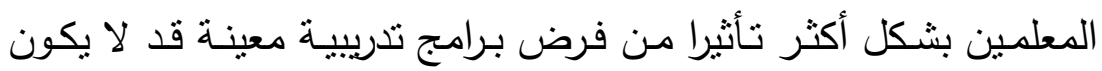
المعلمون في احتياج إليها. r. توجيه نظر المسئولين عن تخطبط العملية التدريبية- للارتقاء بمستوى التهو

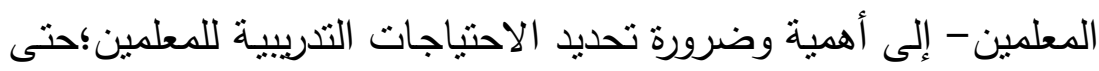
يمكنهم اختيار البرامج التدريبية التي برغبون الالتحاق بها. 
ع. تقديم المقترحـات والتوصسيات التي تسـاعد المسـؤلين والمخططين في إدارات التدريب على تطوير برامج تدريب المعلمين في إطار الاحتياجات التدريبية الفعلية لهم.

\section{منهج الدراسة :}

استخدمت الدراسة الحالية المنهج الوصفي؛ لوصف وتصنيف المصادر والبيانات

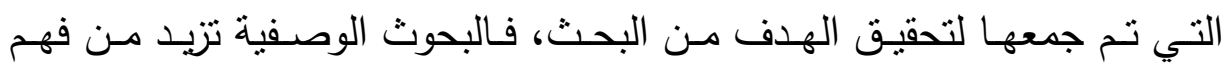
الظواهر التربوية؛ لأنها تحصل على حقائق واقعية عن الظروف القائمة،وتوضح لتحنح

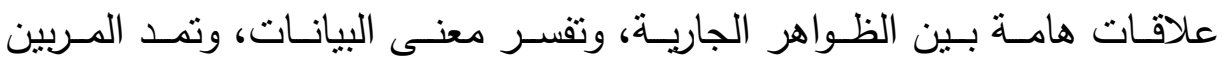
بمعلومات عملية وسريعة الفائدة . وقد تم استخدام المنهج الوصفي في الدراسـة من خـلد وصف وصف وتحليل أدبيات

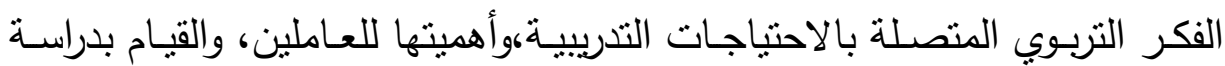

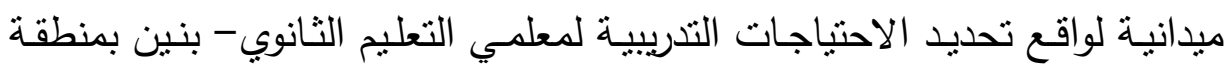

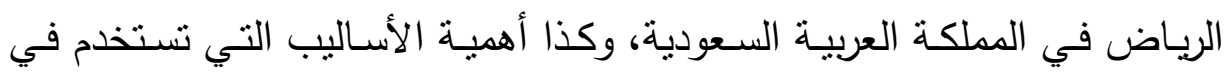
تحديد الاحتياجات التدريبية.

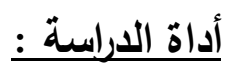

اعتمدت الدراسـة على الاستبانة كأداة رئيسة؛ بهدف تعرف فعالية أساليب تحديد

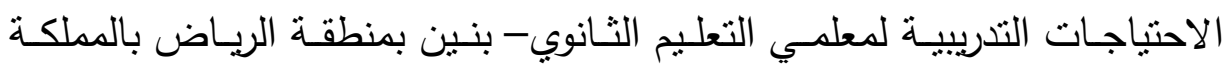

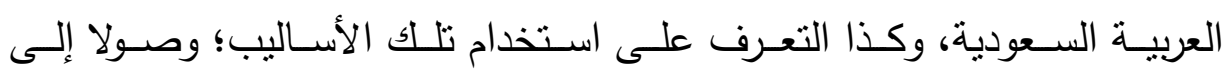

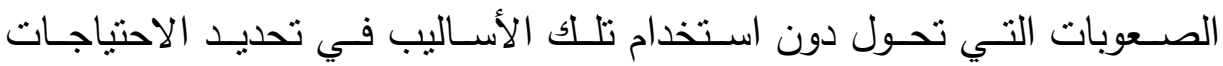
التدريبية.

\section{مجتمع الدراسة وعينتها:}

تمثنل مجتمـع الدراســة الحاليـة فـي معلمـي مــارس المرحلـة الثانويـة الحكومية- بنين بمنطقة الرياض في المملكة العربية السعودية . 
عينـة الدراسـة: تـم اختيـار عينـة عشـوائية مـن معلمي المـارس الثانويـة

بمنطقة الرياض بالمملكة العربية السعودية.

\section{حدود الدراسة}

الحد الموضوعي: تم التركيز على سبل تفعيل أساليب تحديد الاحتباجات التدريبية لمعلمي المدارس الثانوية - بنين بمدينة الرياض بالمملكة العربية السعودية. الحد البشري: اقتصر البحث على عينة من معلمي المدارس الثانوية الحكوميةبنين بمدينة الرياض بالمملكة العربية السعودية.

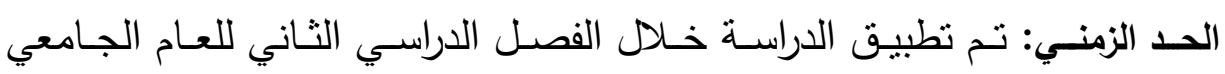

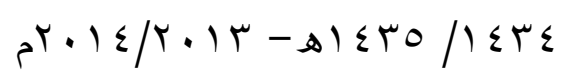
مصطلحات الاراسةة: 1. الاحتياجات التدريبية :

يمكن تعريف الاحتياجات التدريبية إجرائيا بأنها: الفجوة بين المعارف والمهارات

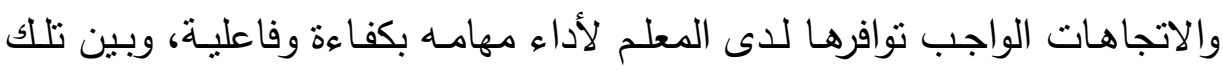
المهارات والخبرات والاتجاهات المتوافرة لديهح حاليا. r . تحديد الاحتياجات التدريبية: مجموعة من المهارات والمعارف والخبرات والاتجاهات المحددة؛ التي يحتاجها المتدرب- في ظروف معينـة- من أجل القيام بأداء مهام وظيفته بشكل أكثر

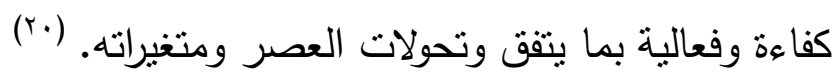
r. أساليب تحديد الاحتياجات التدريبية :

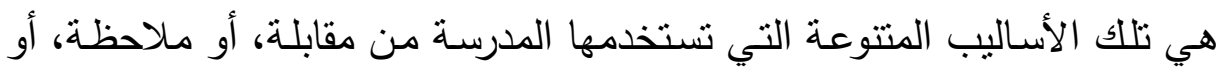

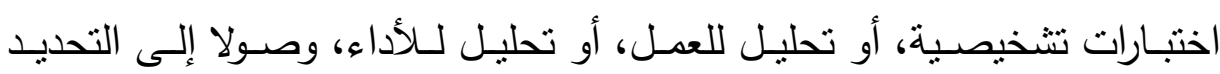
الفعلي لاحتياجات المعلمين التدريبية. الخطوات الإجرائية للاراسة: سارت الدراسة وفق الخطوات الإجرائية التالية: 
أولا: إطار نظري يتضمن عرضا لـ :

1. مفهوم التدريب، وأهدافه ، وأنواعه، وموقع الاحتياجات من مراحل العملية

التدربيية.

r. الاحتياجات التدريبية من حيث( المفهوم، والعناصر والأهداف والأهمية ،

والطرق والأساليب).

ثانيا:الإطار الميداني :

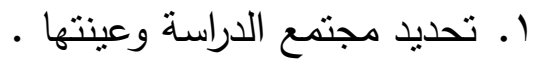

r. تصميم أداة الدراسة.

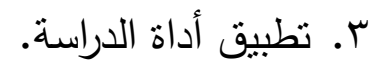

ع. المعالجة الإحصائية.

0. تحليل نتائج الدراسة الميدانية وتفسيرها.

7. استخلاص النتائج النهائية والتوصيات.

أولاً: الإطار النظري للبحث

تمر العملية التدريبيـة بعدة مراحل مترابطـة ومتكاملـة ومتتاليـة فيما بينها، حيث يعتمد كل منها على ما سبق من مراحل، وقد اختلف علماء التدريب في التعبير

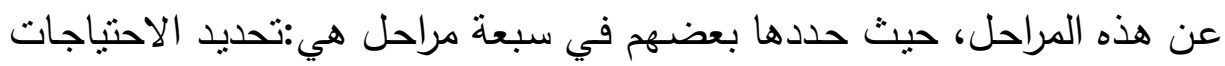

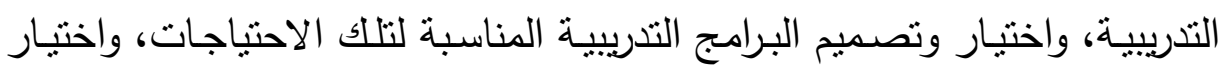
الددربين، واختيار مكان وزمان التدريب، واختيار الطرق المناسبة للتدريب، وتتفيذ ولنئ

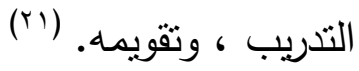

وهناك من عبر عنها بخطوات العملية التدريبية، وحدد لها سبع خطوات هي: ولئ تحديد الاحتياجـات التدريبيـة ، والتحليل ، وصياغة الأهداف، وتصـميم البرنـامج

التدريبي، والتتظيم والتخطيط، وتقديم البرنامج، والتقييم والتغذية المرتدة. (rr)

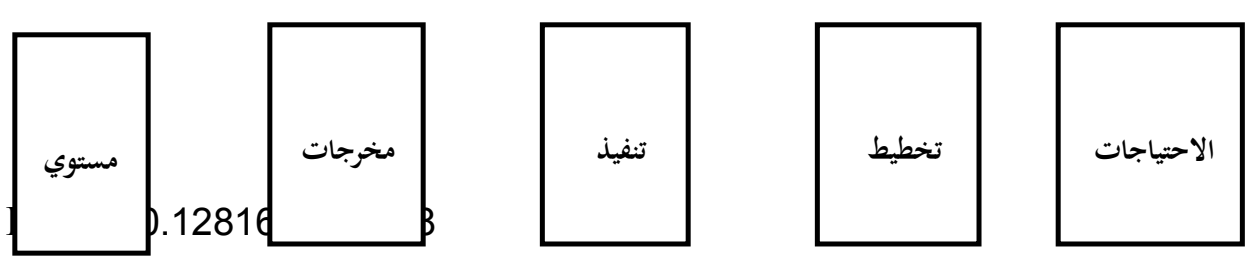



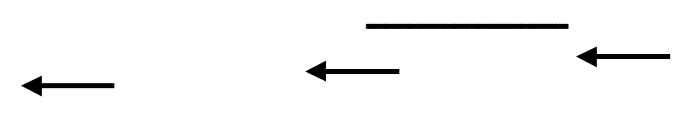

个

شكلي برقمث( ) يويضح مراحل العملية التتريبية

وعلى الرغم من استخدام العلماء والباحثين في مجال التدريب تعبيرات مختلفة عن مناحت

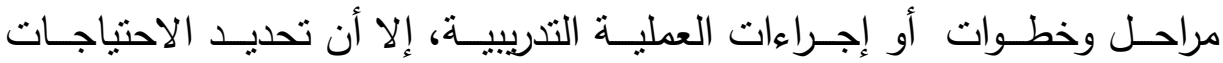

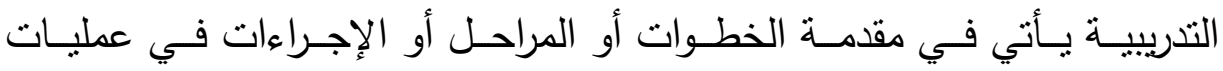

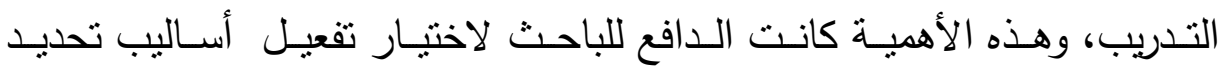

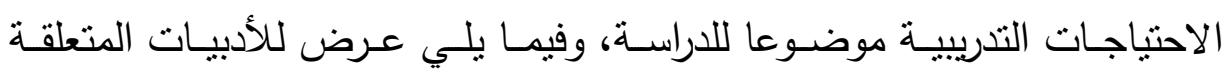
بتحديد الاحتياجات التدريبية. أولا: أهمبة تحدبد الاحتباجات التّربية للمعلمبن

يمثل تحديد الاحتياجات التدريبية العنصر الأساس في نجاح دورة حياة التدريب؛

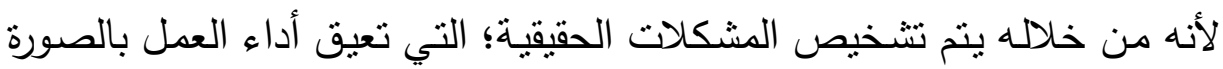
المطلوبة، ومن هنا فإن أي برنامج تدريبي لا يبنى على تحديد دقيق للاحنياجات التدريبية للمتدربين لا يكون مؤثرا، وقد يكون إهدارا للإمكانيات البشرية والمادية.

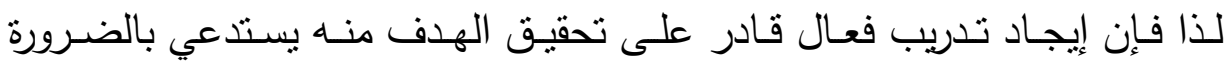

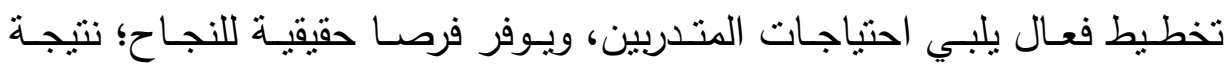
ارتباطه بالاحتياجات الخاصة لكل فئة من فئات العاملين بالمؤسسة. وتعد مرحلة تحديد الاحتياجات التدريية هي البداية الأساسية في سلسلة الحلقات المترابطة من حلقات العملية التدريبية، وهى الركيزة الأسـاس لبناء برامج تدريبية

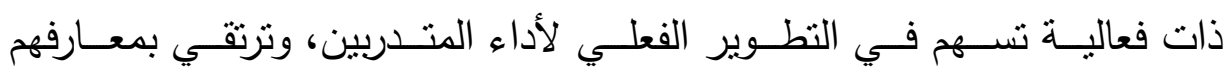

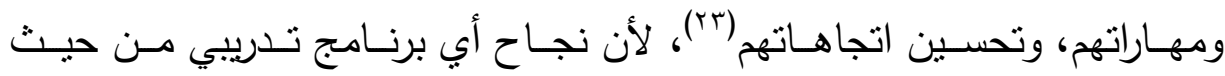
التخطيط والتصميم يتوقف على مدى تعرف الاحتياجات التدريبية لدى المعلمين،

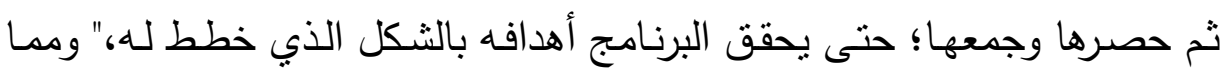




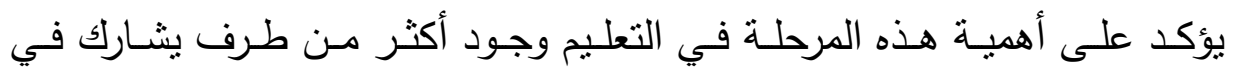

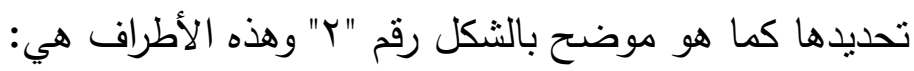

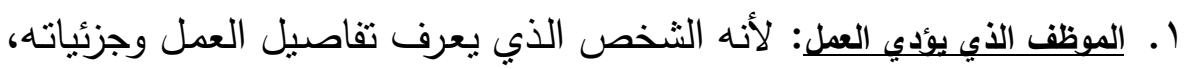

$$
\text { ويواجه مشكلاته اليومية. }
$$

r. المدير أو الرئيس المباثر: لأنه الثخص الذئه يثرف لئه على الموظف، ويعرف

$$
\text { طبيعة عمله والمهام الموكلة إليه. }
$$

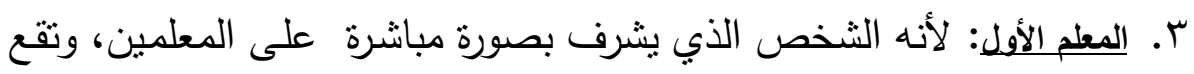

$$
\text { ضمن مسئولياته تحديد الاحتياجات التدربيية للمعلمين. }
$$

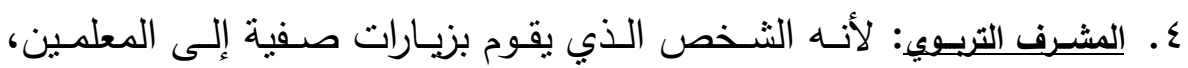

$$
\text { ويتعرف عن قرب على جوانب القوة ونقاط الضعف في أداء المعلمين. }
$$

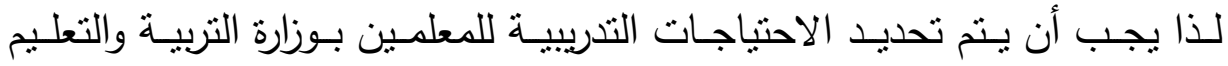
بطريقة علمية سليمة؛ لكي تتمكن إدارة التدريب والتطوير المهني بأقسامها المعنية من تحديد الكم والنوع للمعارف والمهارات اللازم توافرها في البرامج المراد تتفيذها.

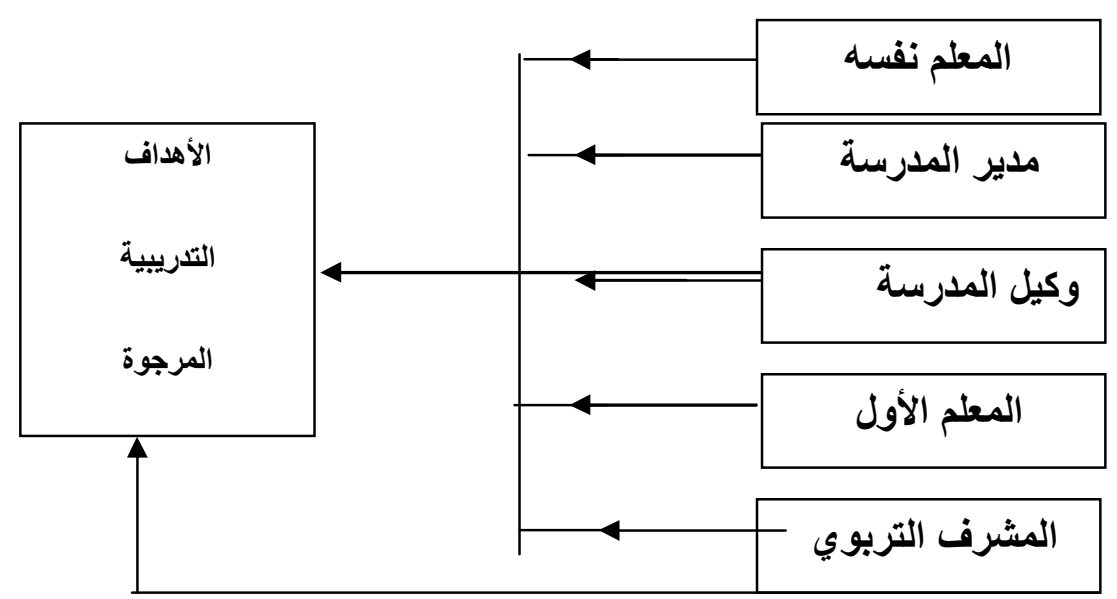

شكل ( r) الأطراف المشاركة في تحديد الاحتياجات التدريبية للمعلمين 
ومن هنا تتبع أهيـة تحديد الاحتياجات التدريبية؛ باعتبارها الأسـاس الأول لبناء

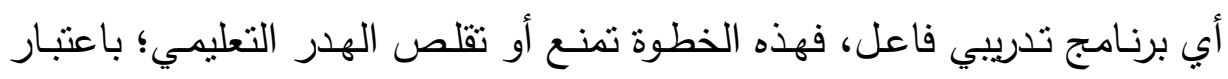

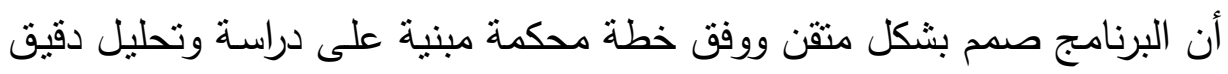

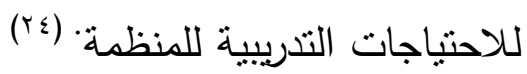

\section{ثانبا : مفهوم تحبد الاحتباجات التدريبية للمعلمبن}

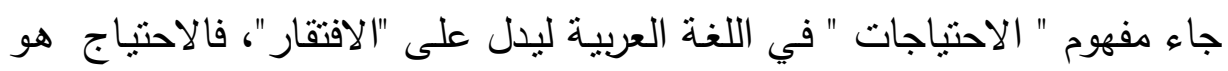

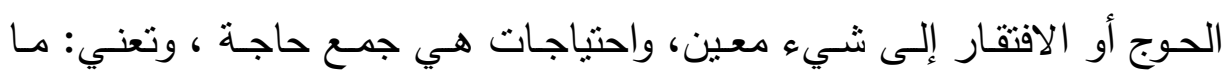

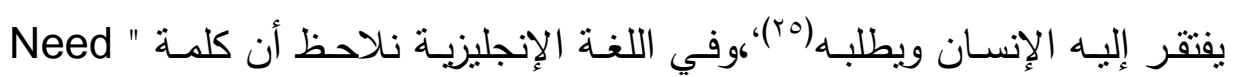

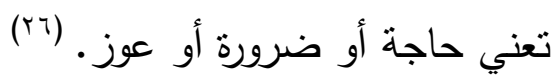
وتعددت آراء المتخصصين في حقل التدريب حول مفهوم الاحتياجات التدريبية:

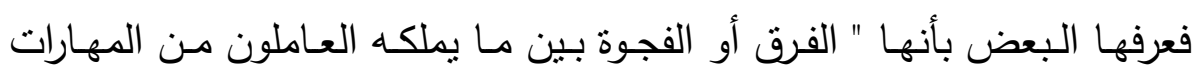

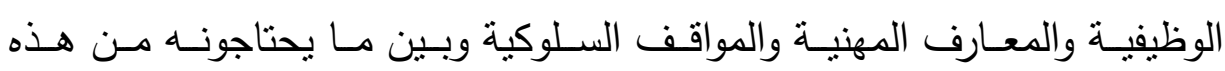
المنطلبات لأداء المهام الموكولة إليهم ".(rV)

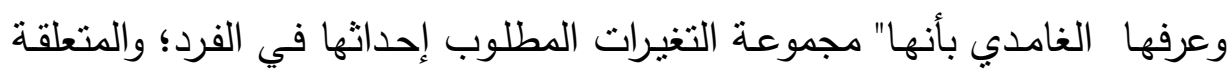

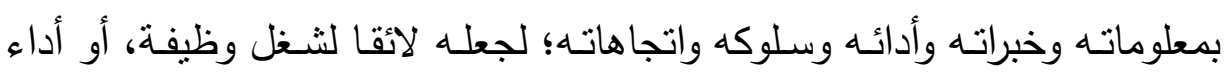
اختصاصات وواجبات وظيفته الحالية بكفاءة عالية"، ثم عرف تحديد الاحتياجات التدريبية بأنها" العمل على تقدير الحجم الكافي من الاحتياجات التدريبية اللازمة وطية للمتدرب؛ والتي تعطي بواسطة متخصصين في التدريب التربوي، وبطرق علمية؛

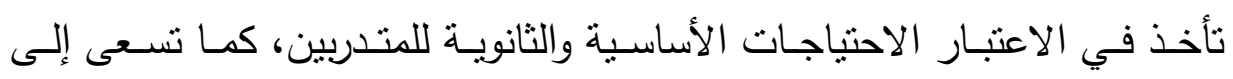

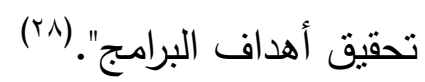

وبعض الباحثين يرى أن مفهوم الاحتياجات التدريبية يتعلق ببعدين زمنيين، هما:

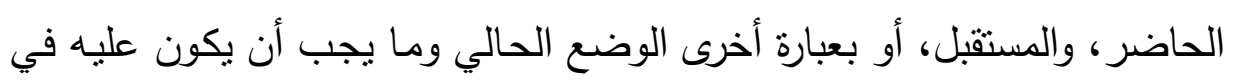

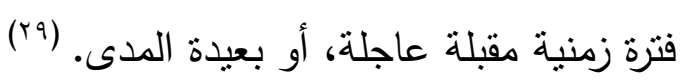


ويـرى" علــي الســلمي " أن الاحتياجـات التدريبيـة تعبيـر عـن الأفـراد المطلـوب

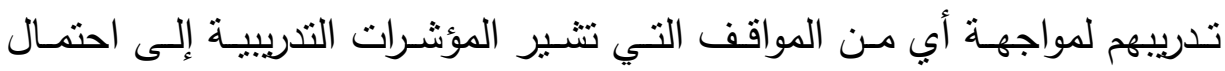

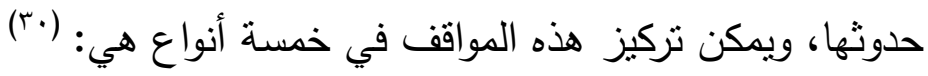

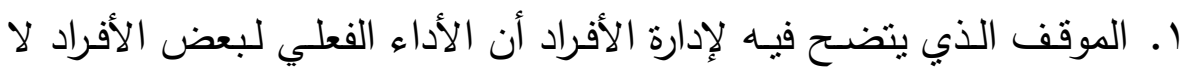

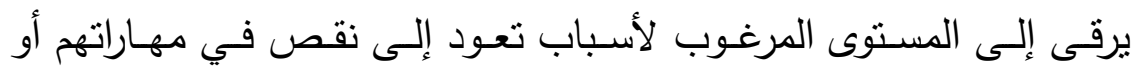
معلوماتهم. r. الموقف الذي تقرر فيه الإدارة تغيير وصف الوظيفة من حيث المسئوليات،

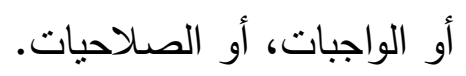
r. الموقف الذي تقرر فيه الإدارة تغيير الظروف والإمكانيات التي يتم فيها أداء العمل، أو يتم العمل بواسطتها، مثل إعادة هيكلة المؤسسة، استحداث أقسام جديدة، إدخال الحاسب الآلي في كل عمليات المؤسسة.

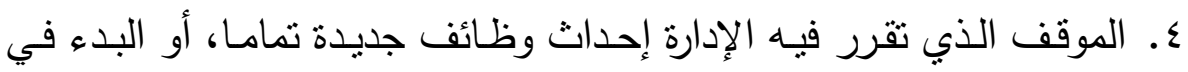
أنشطة جديدة لم يسبق لأفراد المؤسسة ممارستها من قبل.

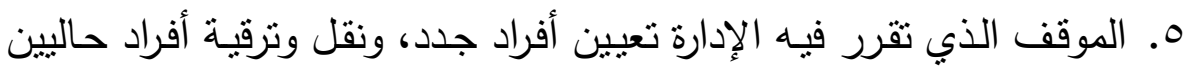
إلى وظائف مختلفة عن وظائفهم الحالية.

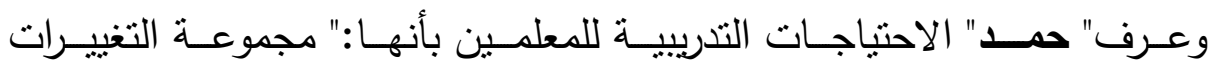
والتطويرات المطلوب إحداثها في معلومات المعلم،وسلوكه/ ومهاراته، واتجاهاته،

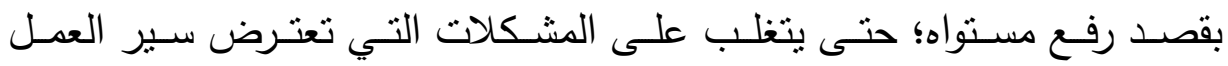
والإنتاجية لديه".(r) في ضوء العرض السابق يتضح ما يالي:

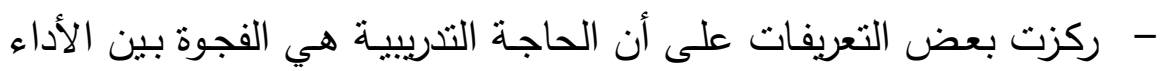
الفعلي وبين الأداء المطلوب. - أوضحت بعض التعريفات أن الحاجة التدريبية عبارة عن نقطة ضعف، الف أو قصور تحتاج إلى تقوية. 
- ـ وذكرت بعض التعريفات أن الحاجة التدريبية عبارة عن تغييرات مطلوبـة لمواجهة مشكلات العمل.

- موصـفت بعض التعريفـات الاحتبـاج التدريبي على أنـهـ تقـويم للوضـع الحاضر لمعالجته وتعديله مستقبلا.

تأسيسا على مـا تقدم يمكن للباحث أن يستخلص تعريفا للاحتياجات التدريبية، فيرى أنها: تلك الخطوات المنظمة التي يتم اتباعها داخل الإدارات والمدارس؛ للكثف عن النقص أو التتاقص(الفجوة) بين الوضـع المرغوب فيـه وبين الوضـع القـائم في قدرات المـوظفين لأداء الأعمـال الحاليـة والمسـتقبلية، ويـتم ذلك مـن خلال:

تحديد الأعمـال المطلوب إنجازهـا مـن الفرد، ومـا تتطلبه تلك الأعمال مـن

$$
\text { معارف ومهارات واتجاهات. }
$$

تحديد الأداء الفعلي للفرد من الناحيتين الكميـة والنوعيـة، ومـا يملكه بالفعل

$$
\text { من المعارف والمهارات والاتجاهات. }
$$

المقارنة بين الأداء المطلوب وبين الأداء الفعلي(فجوة الأداء) وتحديد سبب تللك الفجوة، فإن كان السبب راجعا إلى نقص في المعارف أو المهارات أو الاتجاهات؛ كان هذا (احتياجا تدربيبا)

\section{ثالثا: عناصر تحدبد الاحتباجات التدريبة:}

مـن الطـرح السـابق لمفهوم الاحتياجـات التدربيــة يتضـح أنهـا تتمثل في ثلاثتة عناصر رئيسـة يتعين على المعنيين بتحديد الاحتياجات التدريبية للعاملين سواء بإدارات الوزارة أو المدارس معرفة خصائص كل منها ، لأن معرفة خصائص ما يـراد تغييـره يمثنل نقطـة البدايـة في إحداث أي تغييـر، وفيمـا يلي توضـيح تلكك

العناصر : (r)

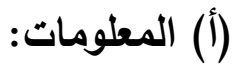


ويقصد بذلك:الحصول على معارف وأفكار جديدة مع فهها واستيعابها إلى الحد

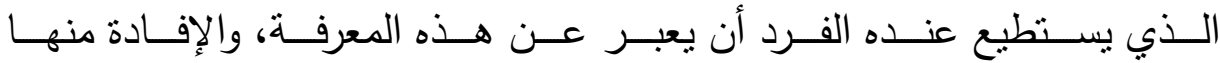

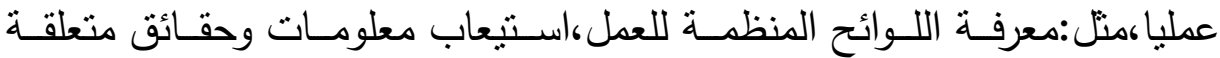
بموضوع معين، بحيث يؤدي تعلمها إلى تحسين أداء الفرد.

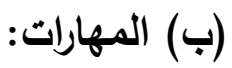

أي اكتساب الفرد القدرة على استخدام وسائل جديدة بطريقة فعالة، واستخدام نفس الوسـائل بطريقـة أكثر كفاءة، ويلزم الحصـول عليها توافر عاملين رئيسين هـا: الممارسة، والتفاعل الصحيح مع الموقف التدريبي.

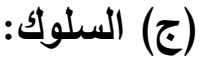
ويقصد بـللك: اكتساب نزعات لتصـرف نحو الأشياء أو الأثخاص أو المواقف بطريقة جديدة، وبمعنى آخر تكوين مسلك ذهني، أو عادة فكرية إيجابية تجاهها، وهذا يتطلب محو عادات واتجاهات قديمة قبل تثبيت الاتجاهات الجديدة، وهنا لا لانيات

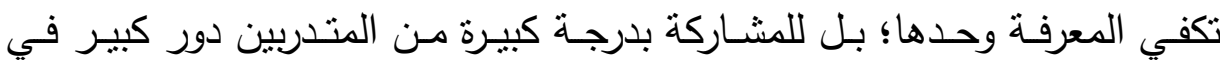
ترسيخ هذه الاتجاهات، وكل زيادة في المعرفة لا يصحبها تغيير في الاتجاهات تعتبر تغييـرا توقف عند حد المعرفة فقط،وبالتالي يكون هنـاك انفصـال بين مـا يقوله الفرد وبين ما يفعله.

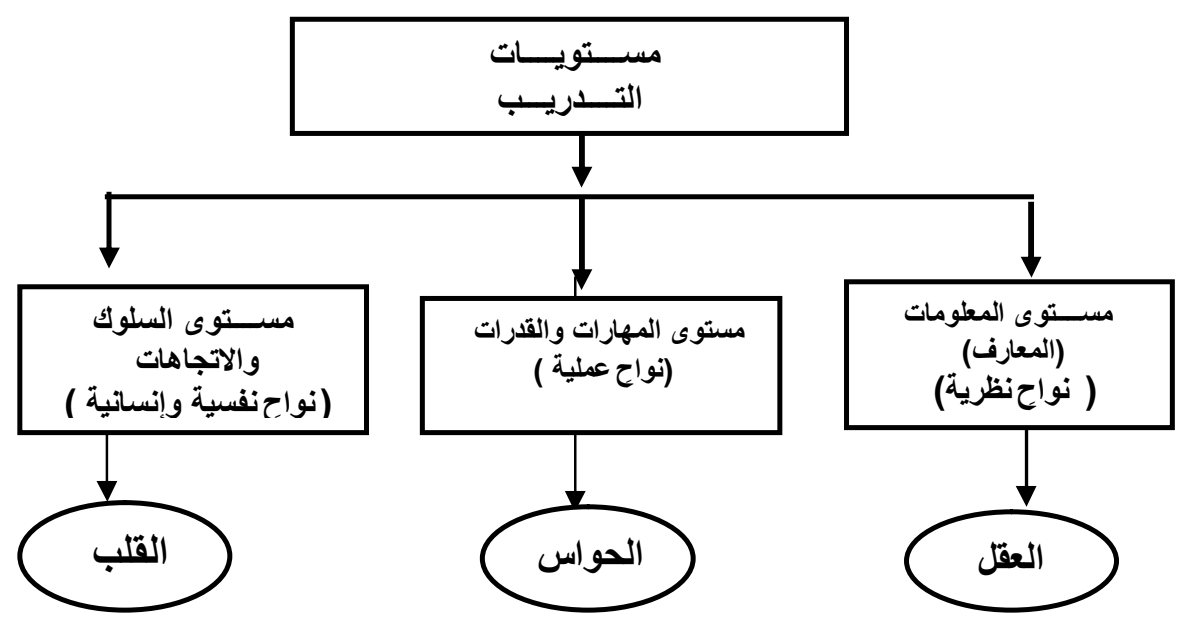


شكل (r) يوضح عناصر تحديد الاحتياجات التدريبية للمعلمين

$$
\text { رابعا: أهداف تحديا الاحتياجات التدربيية : }
$$

تسعى عملية تحديد الاحتياجات التدريبية إلى تحقيق الأهداف التالية:(rr) (أ ) )وضيح الفئة المستهدفة من التدريب. (ب) تحديد معدلات الأداء المناسبة. (ج) توفير المعلومات الأساسية للتخطيط الجيد للتدريب. (د ) تقدير الاحتياجات التدريبية المستقبلية اتهية (ه) إتاحـة الفرصـة لتحسين أداء العـاملين وزيـادة كفاءتهم مـن خـلا انتقال أتر التدربب. (و) كثف مستوبات الأفراد المطلوب تدريبهم ومجالات التدريب اللزمة لهم. (ز) مساعدة إدارات التدريب في وضـع استراتيجيات وخطط طويلة المدى لهيكل التدربب، وتتظيمه ، وتوجيه سياساته ، وبرامجه ، وخدماته، وممارساته.

\section{خامسا: .مصادر تحديد الاحتياجات التدربيية للمعلمبن :} تُّتخلص الاحتياجات التريبية من كل أو بعض المصادر التالية:

\section{Organization Analysis المصدر الأول : تحليل المنظمة} المنظمة هي الإطار الكلي الذي بضم الأفراد والوظائف، وهى الكيان المنوط بـه تحقيق أهداف محددة لصـالح المجتمـع، ويتتم تحقيق تلك الأهداف عن طربـق مختلف الأعمال التي تؤدى داخل المنظمة. (عَ)

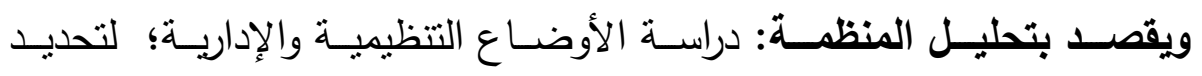
مشكلات الأداء الحاليـة في المنظمـة، وكذلك تحديد متطلبـات الأداء المرتبطة بخطط التطوير (ro)، أي تحديد الإدارة أو القسم الذي يكون فيه التدريب ضروريا بما يتمشى مع الأهداف التي تسعى المنظمة إلى تحقيقها، وبتم ذلك من خلال الخطوات التالية : ت الت 


$$
\begin{aligned}
& \text { • تحليل أهداف المؤسسة. } \\
& \text { هالسياسات واللوائح. } \\
& \text { الهيكل الوظيفي. } \\
& \text { خصائص القوى العاملة. } \\
& \text { استغلال الموارد المتاحة (أي تحليل معدلات الكفاءة). }
\end{aligned}
$$$$
\text { الفعالية(تحقيق النتائج المطلوبة ). }
$$

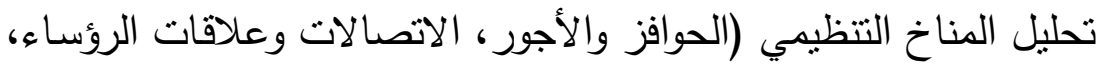

$$
\text { والزملاء ، والتتافس، والثقة ، والمسئولية). }
$$

• تحليل التغييرات المتوقعة في نشاط المؤسسة.

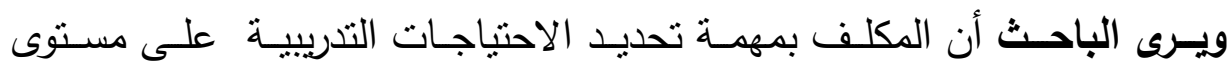

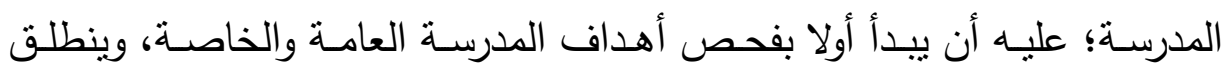

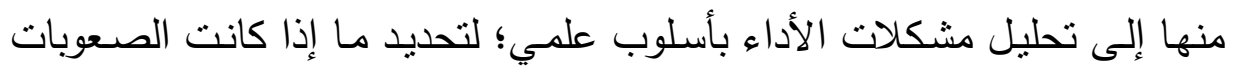
التي تواجه الأداء يمكن التغلب عليها من خـلال إجراءات إداريـة، أم من خـلاهل

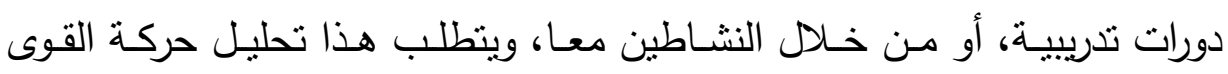

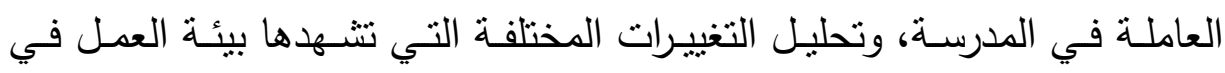

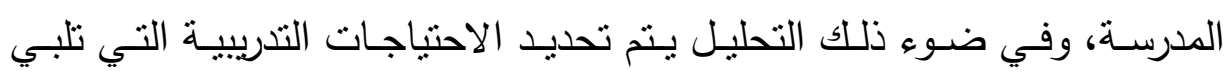
احنياجات المعلمين الفعلية.

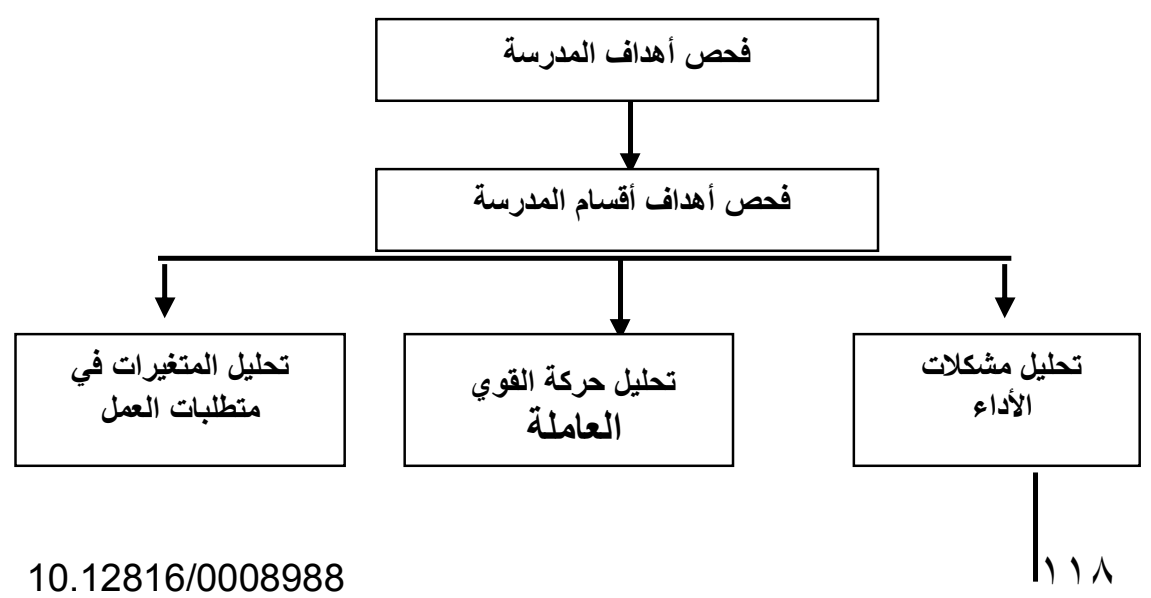




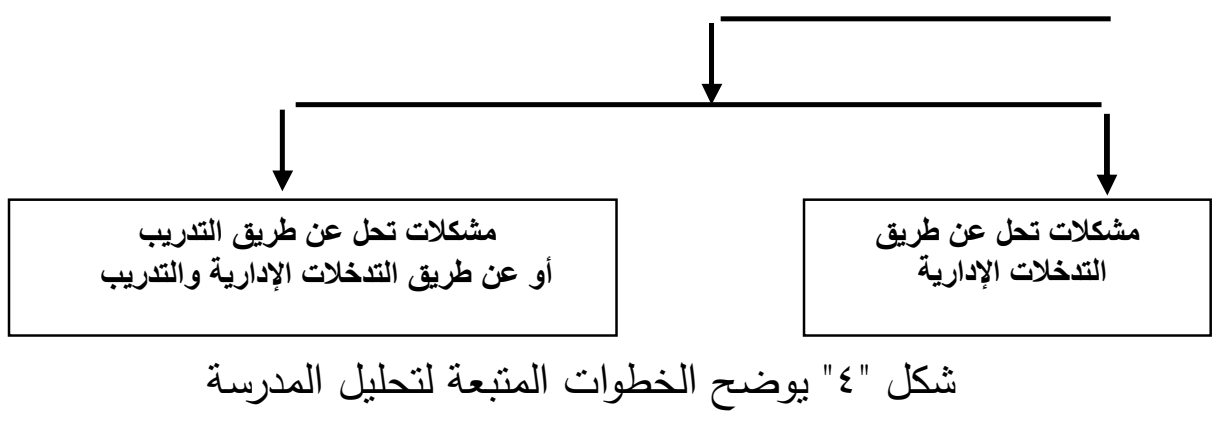

المصدر الثاني : تحليل العمل (الوظيفة)

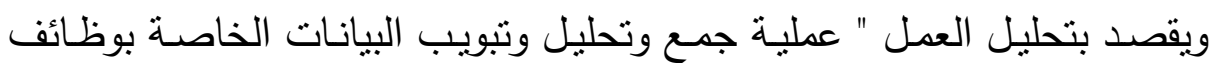

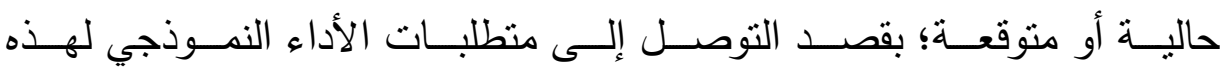

الوظائف". (rT)

ويهدف تحليل العمل إلى تحديد نوع المهارات والمعلومات والاتجاهات المطلوبة؛ لإتمام العمل والمعايير التي تقاس بها درجة تحصيل الفرد لهذه المتطلبات، ويتت

تحليل العمل من خلال العناصر التالية :

التوصيف الوظيفي المعمول به.

مواصفات شاغل الوظيفة.

$$
\text { ظروف أهداف الوظيفة. }
$$

معايير الأداء : تحديد نوعية ناتج العمل وكميته لفترة زمنية معينة.

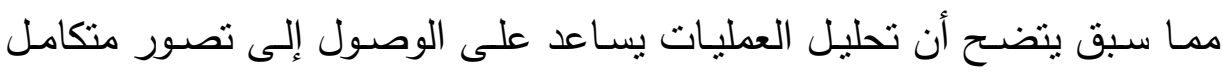

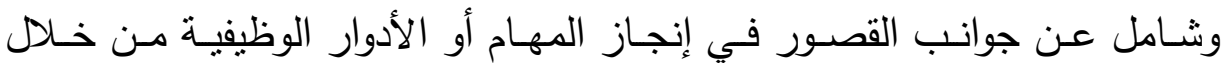
المقارنــة بين المعايير المحددة لـلأداء (مستوى الإنجـاز المعياري وبين الإنجاز الفعلي والحقيقي؛ حتى تكتتف المقارنـة أسباب الانحرافات في مستوى الإنجاز ،

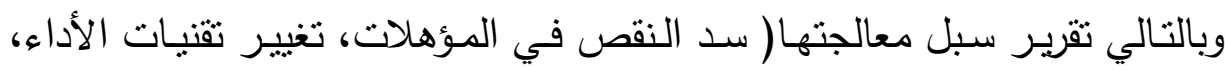

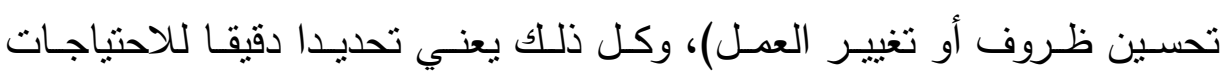


التدريبية، ويقدم مؤشرات تفصبلية للـرامج التدربيسة المطلوبـة لتحسين كفاءة الأداء.

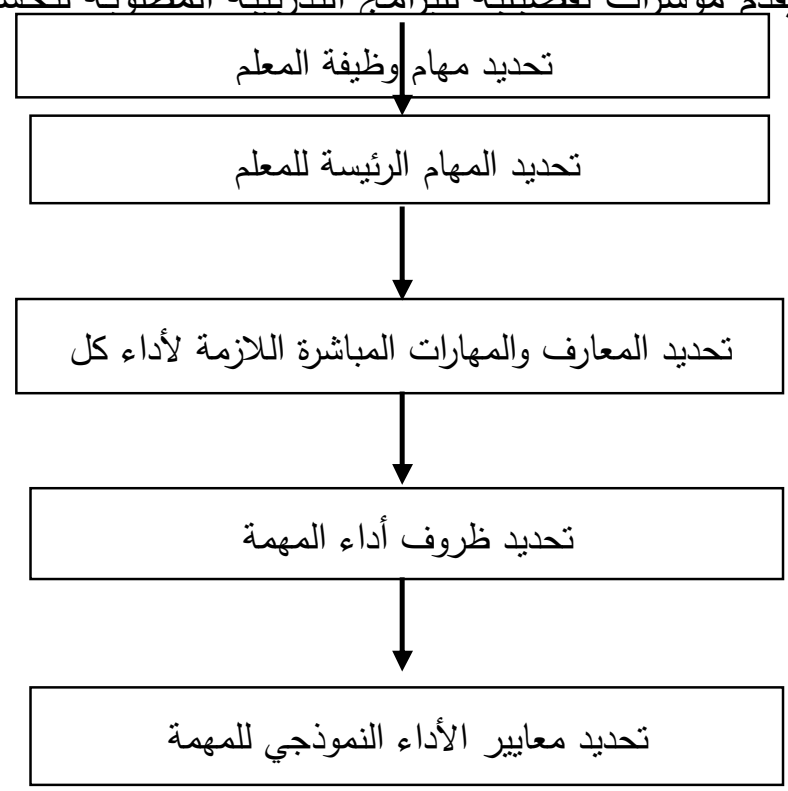

شكل " ه " يوضح الخطوات المتبعة لتحليل العمل والوظيفة بالمدارس

\section{المصدر الثالث: تحليل الفرد}

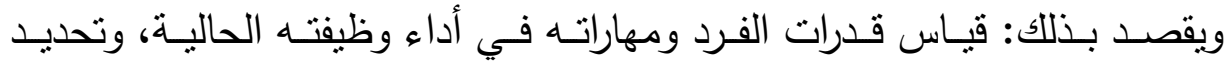
المعـارف والمهـارات والاتجاهـات المطلوبـة اللازمــة لتطـوير أدائـهـ في وظيفتهـه

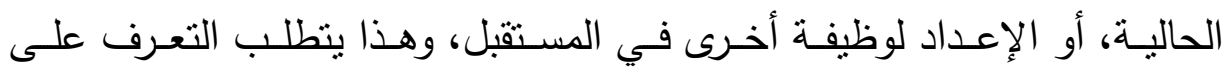
الصفات الثخصية للفرد ومواصفاته الوظيفيـة، والكفايـات المهنيـة المتوفرة لديـهـ

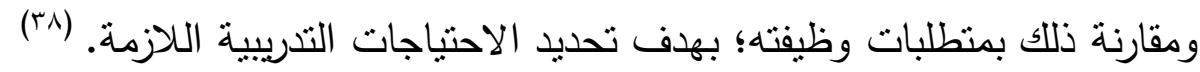
وتهدف هذه الطريقـة إلى معرفـة الأفراد الذين يحتـاجون للمشـاركة في دورات

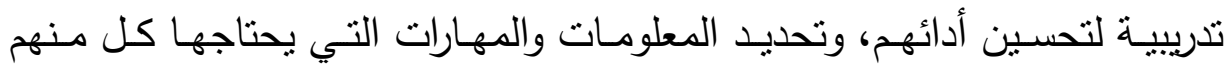
للتدريب عليها في ضوء المنطلبات النموذجية لأداء المهام الحيوية لوظائفهم. ويتم تحليل الأفراد وفقا للأسس الرئيسة التالية: (ra) 
ا .تحليل الأفراد حسب المستوى الوظيفي: بمعنى تقسيم الأفراد إلى مستويات

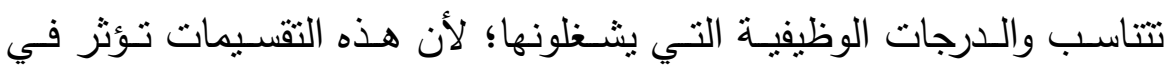

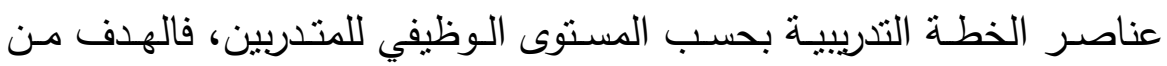
تحليل الأفراد حسب المستوى الوظيفي هو تقسيمه إلى فئات متجانسة؛ بهدف تحقيق أعلى درجة من الفاعلية التدريبية.

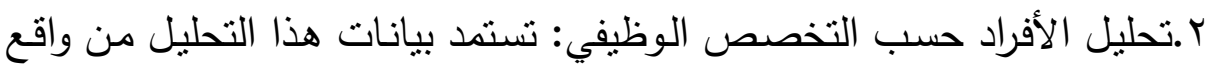
وصف الوظائف ودراسات العمل، ويساعد مساعدة مباشرة في اختيار المادة

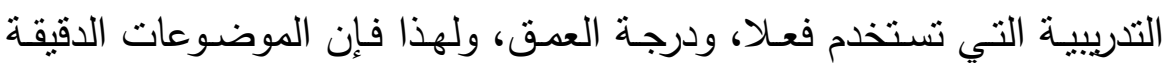

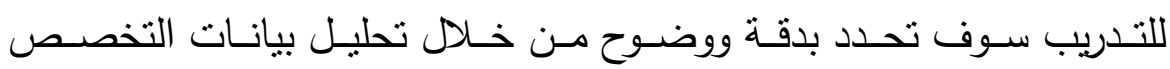

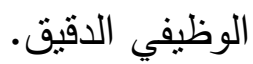
r.تحليل الأفراد حسب المؤهل الأساسي:ويعني ذلك تصنيف المتدربين حسب المؤهلات؛ سواء من حيث نوع المؤهل، أو مستواه، ويهدف هذا التحليل إلى الى ني

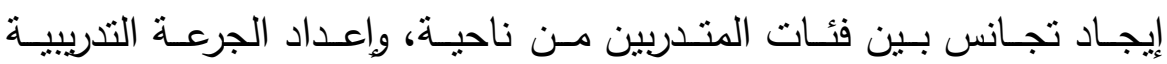
المناسبة، وبالتالي جعل العمل التدريبي أكثر كفاءة.

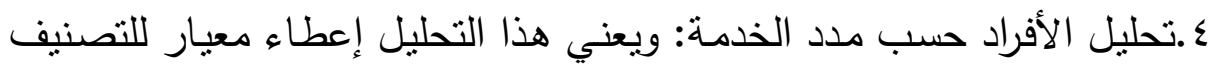

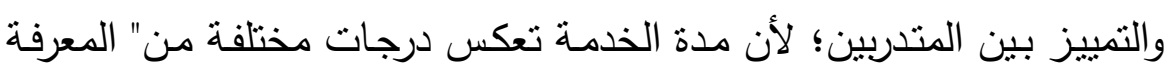
الوظيفيـة، والقدرة على الاستيعاب ومتابعـة التدريب، وتقبل التدريب، والقدرة

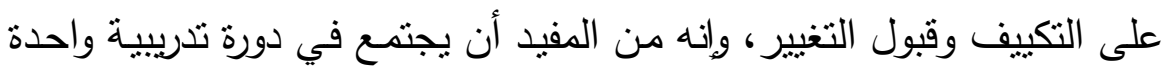
أفراد متجانسون من حيث مدة الخدمة، والعكس يؤدي إلى ضعف الإفادة. ه.تحليل الأفراد حسب التدريب السابق: ويعنى تصنيف المتدربين حسب التدريب الذي سبق أن حصلوا عليه(كما ونوعا)، والهدف مـن ذلك أن يؤخذ التاريخ

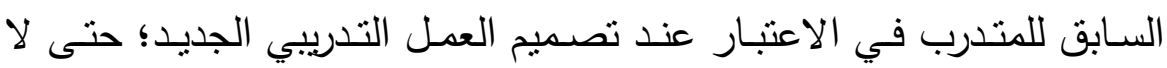
يتكرر التدريب السابق مع التدريب الحالي، أو يكون أقل مستوى منه. 
7 .تحليل الأفراد حسب تقارير الكفاءة: والهدف من ذلك أن يحقق التجانس بين المتدربين حسب تقارير الكفاءة، ويؤخذ ذلك من آخر تقرير كفاءة أو منوسط

$$
\text { عدد من التقارير • }
$$

من الطرح السابق يتضح أن طريقة تحليل المنظمة تحدد الإجابة عن: أين نحتاج

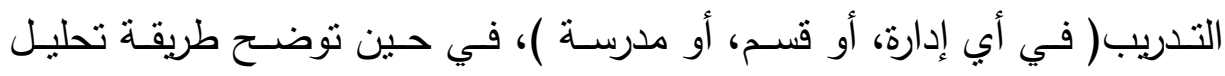

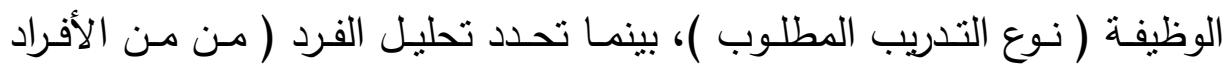
يحتاج إلى تدريب).

نحتاج التتريب ؟

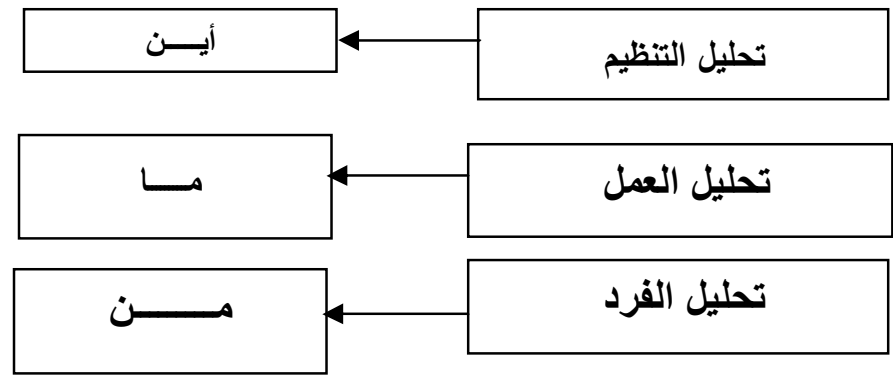

شكل " ج " يوضح كيفية تحديد الاحتياجات التدريبية

والتحليل النـاجح لأي مـن المستويات الثلاثتة المذكورة(المنظــة، الوظيفة، الفرد)

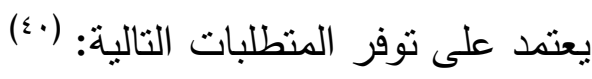
أن يقوم به أفراد متخصصون. أن تستخدم فيه الأسس والأساليب العلمية. أن توفر له الإمكانات المادية اللازمة.

أن يجد الاهتمام المطلوب من قبل قيادة المؤسسة.

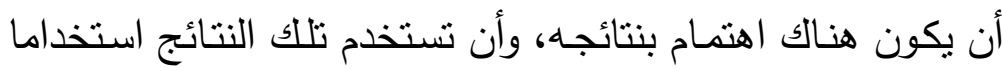

$$
\begin{aligned}
& \text { ملموسا لغرض تحديد الاحتياجات التدربيية. } \\
& \text { هأن يجرى بصورة دورية وليس مرة واحدة. } \\
& \text { سادسا: أسالبي تحبي الاحتباجات التتريبية للمعلمين }
\end{aligned}
$$


تتحدد الاحتياجات التدريبية من خـلال المواءمـة بين غايات وزارة التربية والتعليم

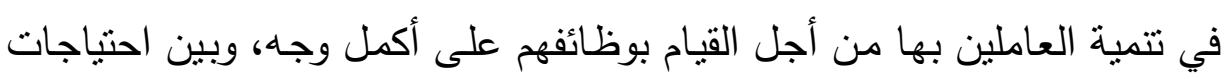
الوظيفة في مجالات العمل، وبين احتياجات المتدرب للترقي والتأهيل، ولكي يتم لتهن

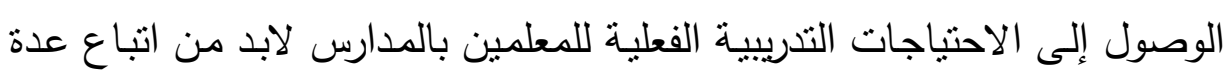

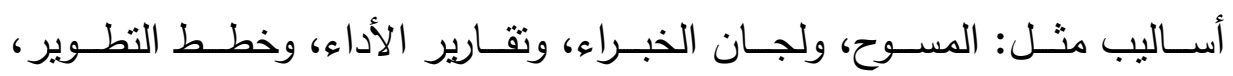

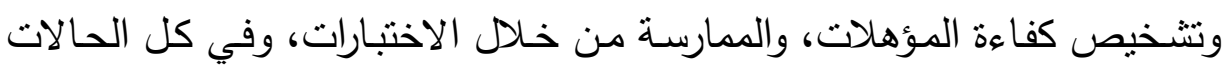

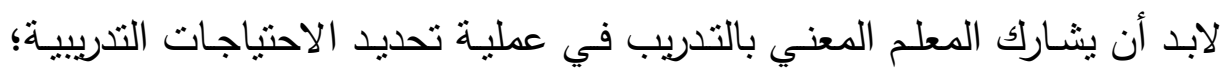

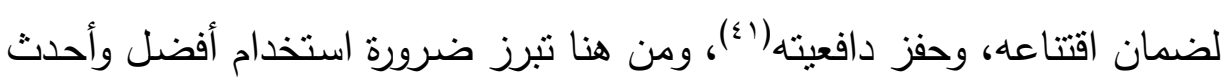

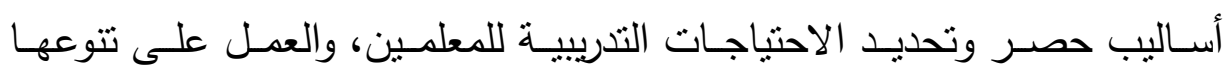

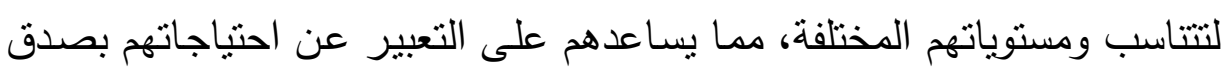

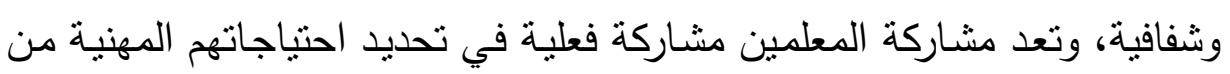
أفضل الوسائل التي تساعد على نجاح برامج التطوير المهني للمعلمين.

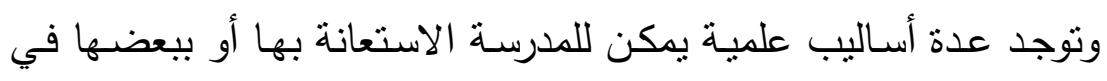

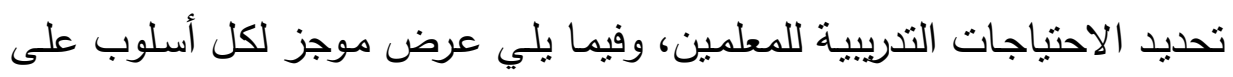
حدة:

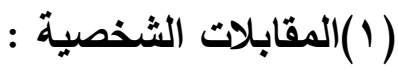

وتتم مع شاغل الوظيفة نفسه، ومع رئيسه المباشر ، وتتم أيضا بصورة مزدوجة مع العيه الرئيس والمرؤوس للحصول على معلومات واقعية عن حجم العمل والأجزاء التي لئي

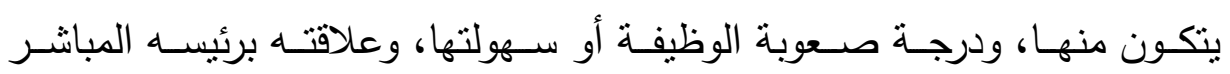

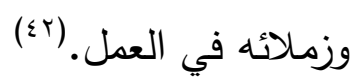
ويتم اتباع هذا الأسلوب داخل المدرسة باستخدام أحد مدخلين: الأول: أسلوب المقابلات الثخصبة الرسمي: ويتم عن طريق الإعداد الجيد للمقابلة،

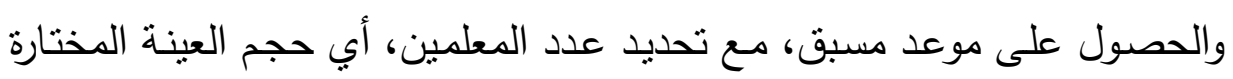


للاراسـة، ويتم إعداد قائمة بالأسئلة التي تتعلق بمتغيرات العملية التعليمية وطرق التدريس المستخدمة. والثاني: أسلوب المقابلات الثخصبة الودي: ويتم عن طريق إجراء مقابلات مـع

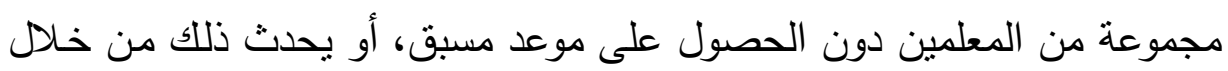

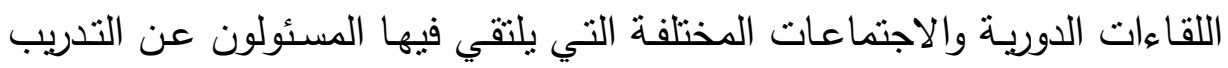

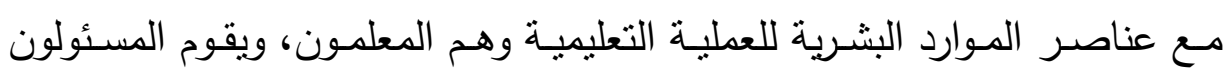
بحصر الاحتياجات التدريبية للمدرسـة، ومن ثم كتابـة تقرير عنها، وإسـالها إلى لى الإدارة التعليمية المعنية. وهذا الأسلوب يمكن أن يتم بشكل نـاجح في ضوء التأكيد على الدور القيادي

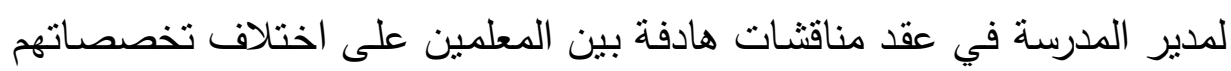

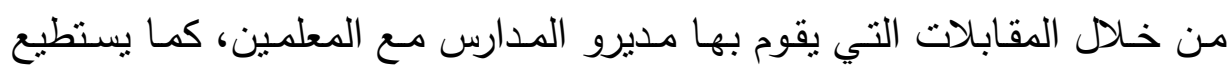

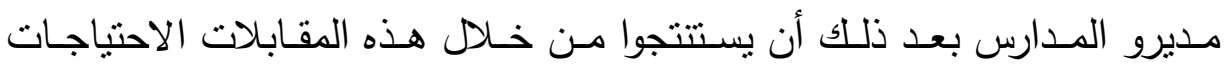
التدريبية الفعلية للمعلمين. (ץ) المقارنة بين الأفراد الممتازين وبين ذوي الأداء الضعيف:

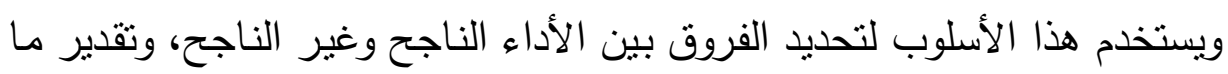

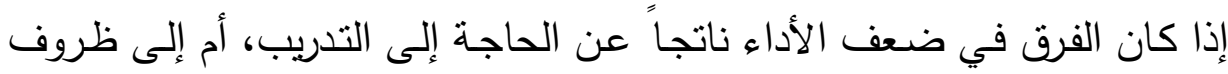

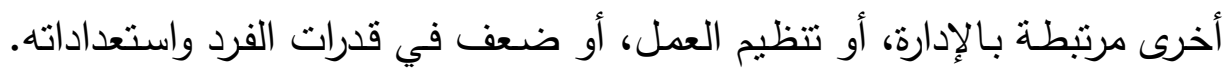

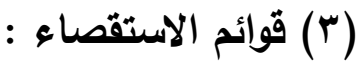

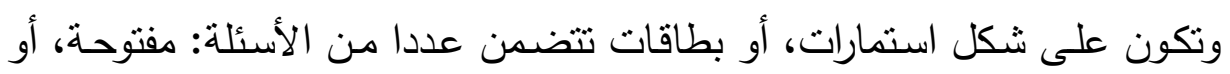

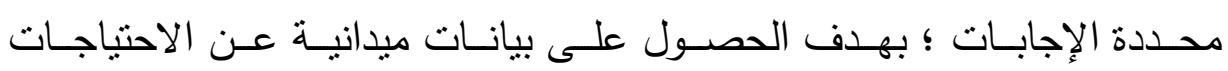

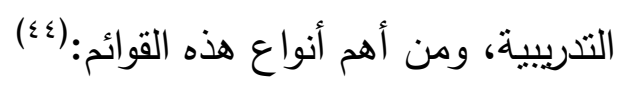

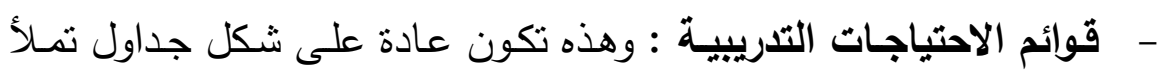
من قبل مسئولي التدريب، أو القيادات الإدارية للتنفيذ . 
- ق قـوائم الانتقــاء: وهذه الأداة تصـمم على شـل جـدول يضـم الخطـوات التفصيلية للأنشطة، أو لطرق الأداء؛ مرتبـة على شكل فقرات متسلسلة منطقيا، وأمسام كل فقرة حقل للملاحظات يقوم الأفراد المجيبون بالتأثير في الحقول التي يجدون أنفسهم بحاجة للتدريب عليها. - البطاقات المصنفة: تعد هذه الوسيلة إجراء لاختبار إجباري، وتتفذ عن طريـق تحضير مجموعة من البطاقات يتراوح عددها من (ه إلى 1 ) بطاقات، وتمثل كل بطاقة حاجة تدريبية في مجال عمل معين، وتصاغ على شـكل سـؤال؛ يبـدأ بعبـارة "كيف؟؟" وهـذه الأسـلة عبـارة عن حاجـة تدريبيـة، وبعد ذلك تعطى هذه البطاقات للفرد المطلوب معرفة أفكاره؛ فيقوم بترتيب هذه البطاقات حسب أهميتها من وجهة نظره.

أداة لقياس وتقييم معلومات ومهارات واتجاهات العاملين المحددة لكل وظيفة، وقد تكون هذه الاختبارات تحريرية، أو شفهية مباشرة، أو غير مباشرة، ومن أهم هذه الاختبارات:

- - اختبارات التعيين،أو الترقية،أو الترشيح للتدريب،وقد تكون هذه الاختبارات

$$
\text { تحريرية، أو شفهية، أو كلاهما معا. }
$$

- تقييم أداء العاملين، وذلك عن طريـق التقارير الدوربـة عن الأفراد، وهذه الطريقة تساعد على كثف الأفراد الممكن ترقيتهم، أو نقلهم إلى وظائف

$$
\text { أعلى. }
$$

- إثارة الحوار كوذلك من خلال طرح مشكلة محددة على مجموعات صغيرة، وبعد المناقثـة تسـل الحلول التي يقترحها الأفراد، ومـن خـلال المناقتـة

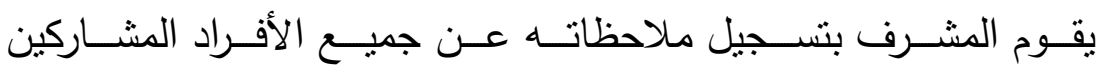
واحتياجاتهم التدربيية. (0) 
هذه الأداة مهينها الحصول على بيانات ومعلومات أساسية عن الخلل والنقص في المعلومات والمهارات والاتجاهات لدى العاملين عن طريق السجلات والوثائق

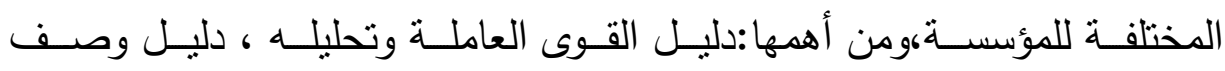

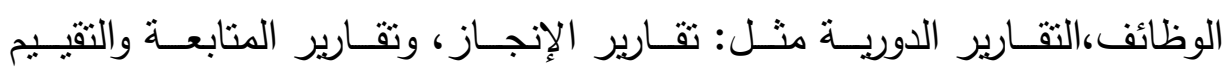

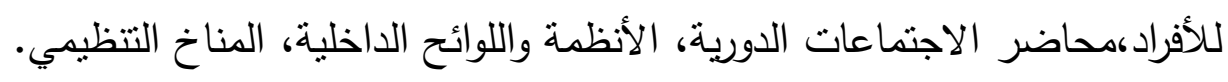
(7) ( الاستشارات )

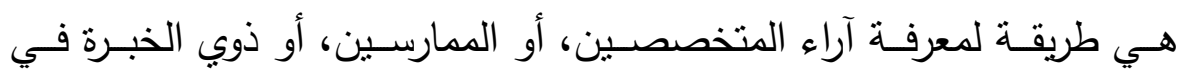

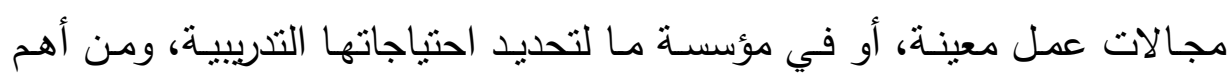

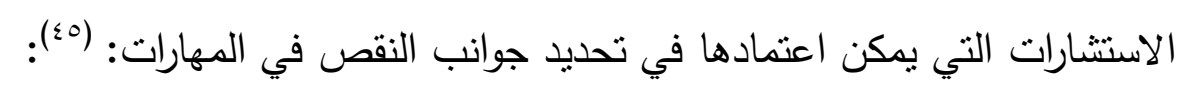

$$
\text { - - الاستشارات الخارجية. }
$$

- اختصاصيو التدريب: حيث يساعدون المختصين في المؤسسات لتقديم المقترحات لحل المشكلات التي تواجه العمل عن طريق تحديد التغييرات المطلوب إجراؤها في مهارات ومعلومات واتجاهات الأفراد.

بطاقة الاحتياجات التدريبية (V)

ويعد هذا الأسلوب من الأساليب الفعالة في تحديد الاحتياجات التدريبية للمعلمين

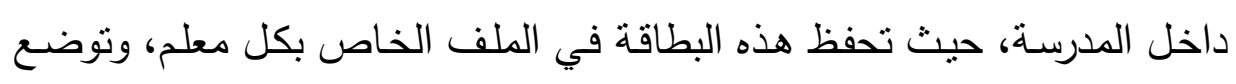
فيها الموضوعات والتواريخ والفترات الزمنية لكل البرامج التدريبية التي حضرها

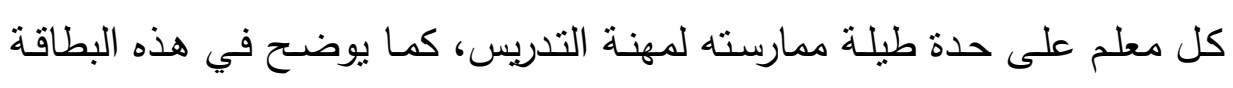

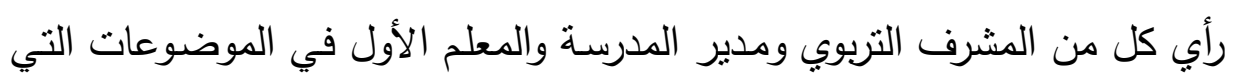

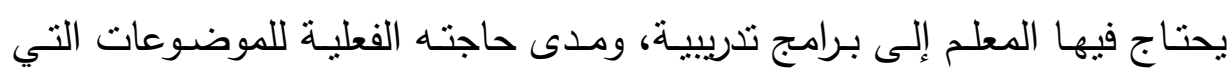
أدرجت من قبل الفئات سابقة الذكر، ومدى تأثير البرامج التدريبية التي حضرها

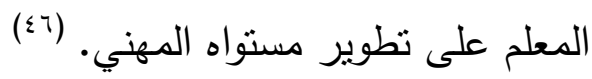


(^) الملاحظـة : وتتــل البحث عـن السـلوك غير المرضـي، والإثـراف غير الكفء، وظروف العمل غير المرضية، وكيف تتجز الأعمال.

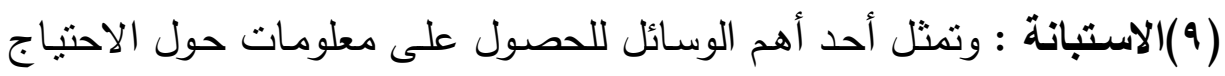

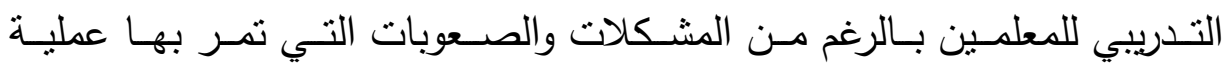

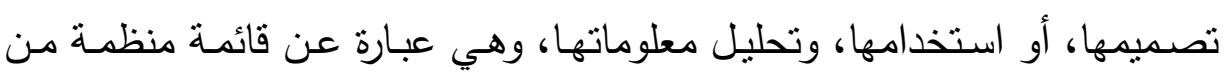

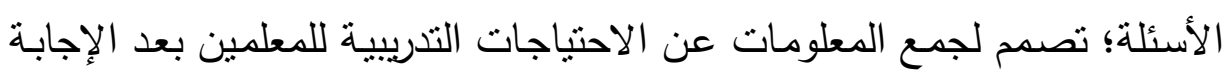
عن الأسئلة من الأفراد الذين يوزع عليهم الاستبانة.

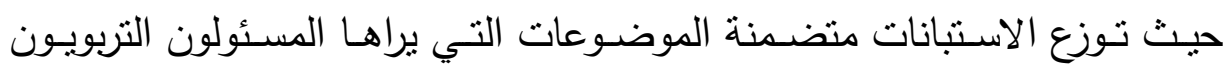

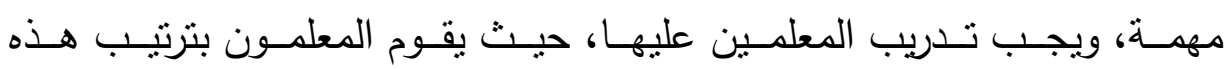

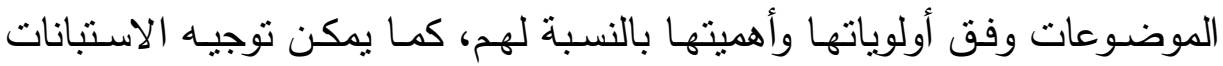
للرؤساء المباشرين؛ للتعرف إلى آرائهم في أداء العاملين؛ والتي تمثل أهمية كبيرة في تحديد الاحتياجات التدريبية؛ نظرا لقدرتهم على تحديد جوانب الضعف والقوة، والمشكلات التي يواجهها العاملون؛ والتي يمكن علاجها بالتدريب.

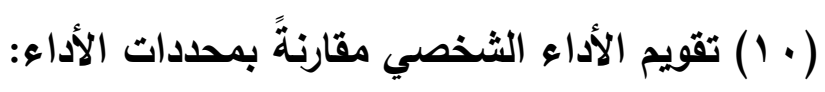

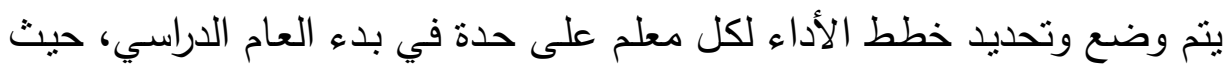

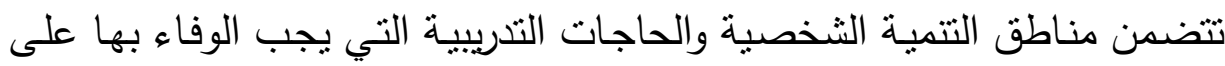

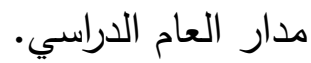
ويقوم المسئول عن التدريب داخل المدرسة بالحصول على الاحتياجات التنريبية

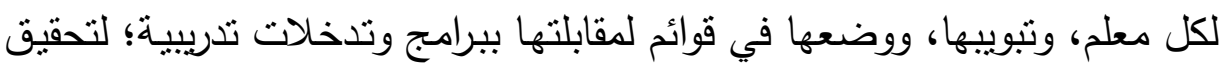
التتمية المهنية والثخصية لكل معلم. وفي نهاية العام الدراسي يتم تقويم أداء كل معلم - تقرير مراجعة الأداء والكفاية-

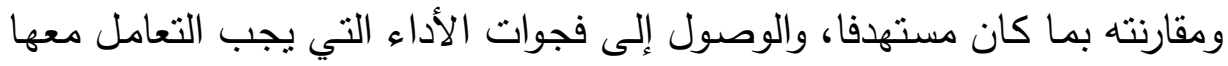
وعلاجها في العام الدراسي التالي. 
ويرى الباحث أن تكامل هذه الأساليب واستخدام كل أسلوب من الأساليب السابقة

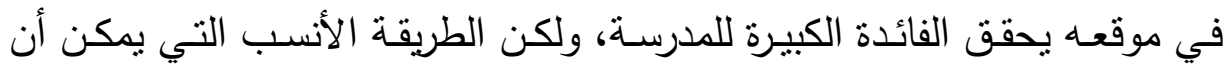
تزيد من دافعية المعلمين للتنريب هي أن نعتمد الأسلوب الذي يترجم الاحتياجات التدريبية للمعلمين من وجهة نظرهم، وبذللك يشعر المعلمون بالتقة بالنفس وبثقة

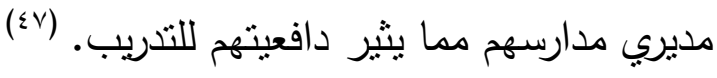
سابعاً: مداخل تحديد الاحتياجات التدريبية في المؤسسات التريوية:

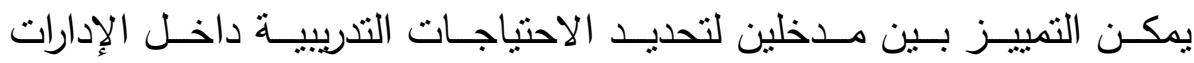
التعليمية، أو المدارس هما:

الأول: الدخل التجميعي: ويكون من القاعدة إلى القمة Bottom- Up Approach وهو المدخل الثائع الذي يبدأ بتحديد الاحتباجات التدربيية لكل معلم بالمدرسة، ثم يقوم بتجميع هذه الاحتياجات خـلال المستويات المتعددة في المدرسة، وفي النهاية يتم تلخيص الاحتياجات التنريبية للمعلمين، وربطها بأهداف المدرسة.

A Top- Down الثاني: المدخل التحليلي: ويكون من القمة إلى القاعدة

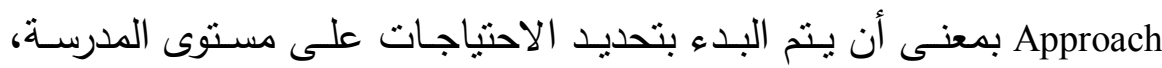

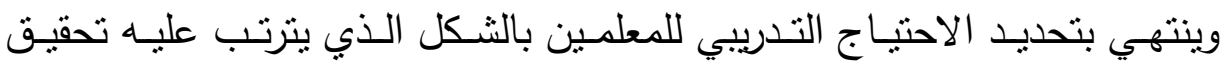

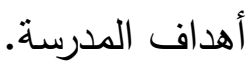

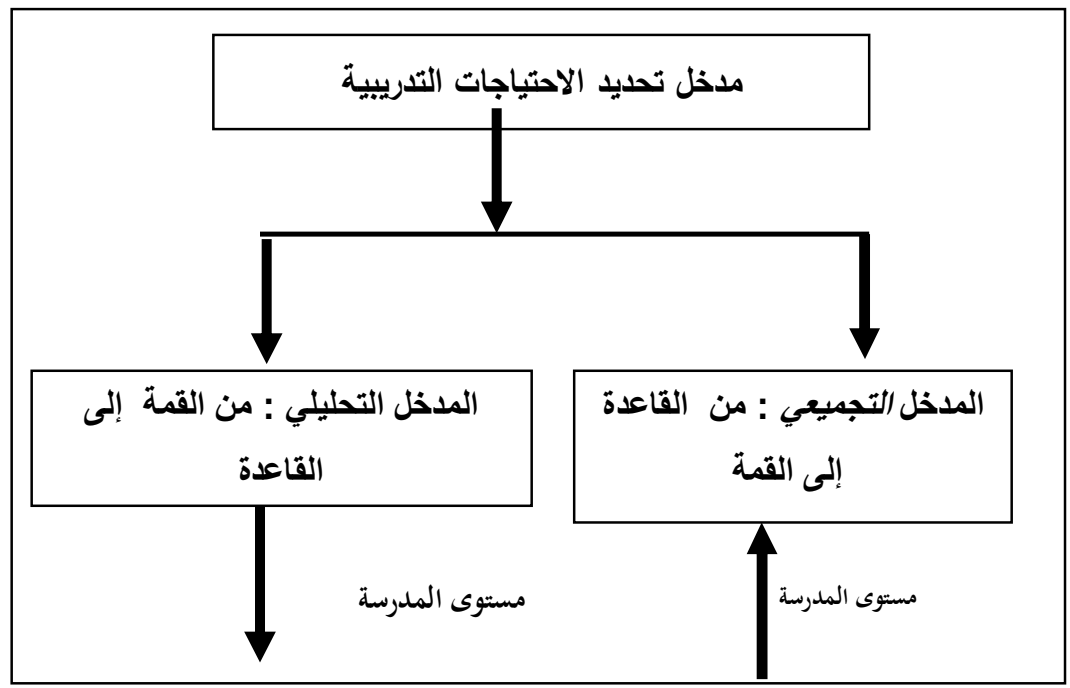

DOI: $10.12816 / 0008988$ 


\section{شكل "V" يوضح مداخل تحديد الاحتياجات التدريبية}

إذن: فتحديـد الاحنياجـات التدربيـة عمليـة تـؤثر وتتأثر ببـاقي مراحل العمليـة التدريبية، بالإضـافة إلى أنها تتأثز بعدد من العوامل المحيطـة بها التي تؤثر على دقتها وكفاعتها؛ كالبيئة التي يتم فيها تتفيذ التدريب داخل المؤسسة ومدى توافر المعلومـات والبيانات اللازمـة لتحديد الاحتياجـات التدريبيـة،وكفاءة وأهميـة النشاط التدرببي والعاملين به، وقيامهح بالدور الموكل إليهح بشكل فعال، وعلى مـن تقـع مسـؤلية تحديـد الاحتياجـات التدريبيـة داخـل المؤسسـةٌ، والظـروف والمعوقات التي تواجه عملية تحديد الاحتياجات التدربيية داخل المؤسسـة سواء

$$
\text { ثأكانتاً ظروفاً مساعدة أو معوقة. }
$$

هدفت الدراسة الميدانية التعرف على آراء معلمي المرحلة الثانوية بمدينة الرياض بالمملكة العربيـة السعودية حول كيفية تفعيل أسـاليب تحديد الاحتياجات التدريبية من خلال.

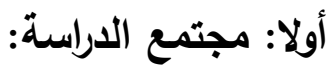

تكـون مجتمـع الدراسـة مـن معلمـي المـدارس الثانوبـة - بنـين بمدينـة الربـاض

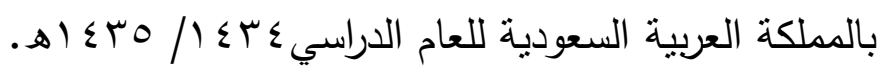
ثانيا: عينة الاراسة

\section{1العينة الاستطلاعية}

قام الباحث بتطبيق أداة الدراسـة على عينة استطلاعية تكونت من م معلما من مجتمـع الدراسـة بهـدف التأكـد مـن صـدق وثبـات الأداة، ومسن ثـم قـام الباحـث باستبعاد أفراد العينة الاستطلاعية من مجتمع الدراسة عند التطبيق النهائي. r-العينة النهائية للاراسة 


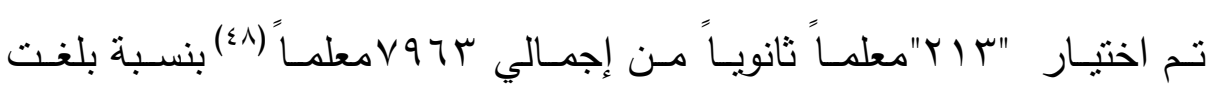

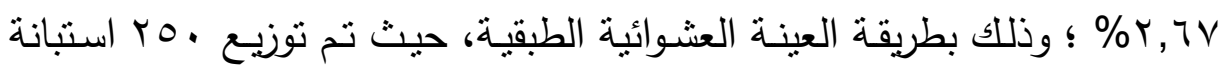

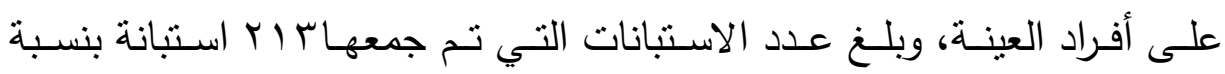
r^o,r ب بالنسبة للعدد الكلي للاستبانات التي تم توزيعها، وذلك من خلال اختيار

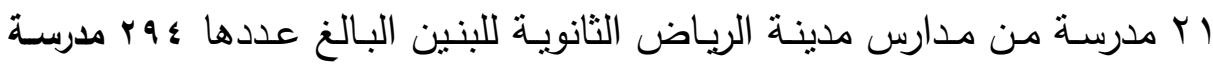

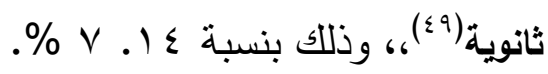

\begin{tabular}{|c|c|c|}
\hline النسبة المئوية بالنسبة لإجمالي العينة & العدد & الوظيفة \\
\hline$\% \wedge \wedge, \vee 9$ & IAV & بكالوريوس \\
\hline$\%$, \% 4 & ir & دبلوم عال \\
\hline$\%$ \%, ० v & $1 \varepsilon$ & ماجستير \\
\hline \% & rir & الإجمالي \\
\hline
\end{tabular}

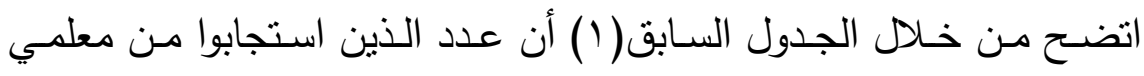
المدارس الثانوية بالرياض قد اختلف طبقا لمتغير المؤهل العلمي، حيث لوحظ أن

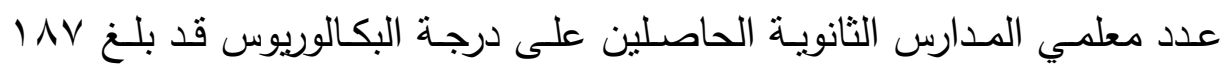

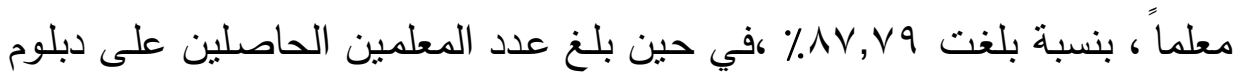

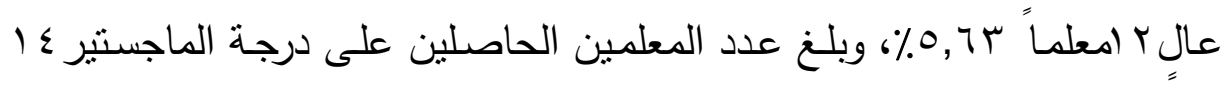

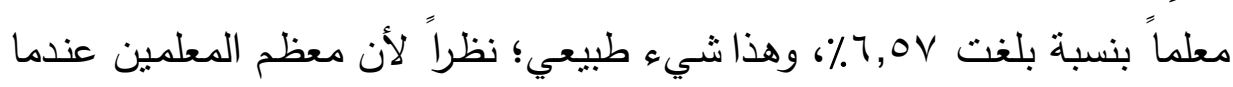

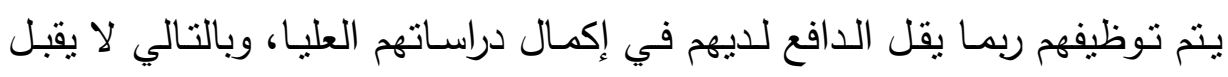

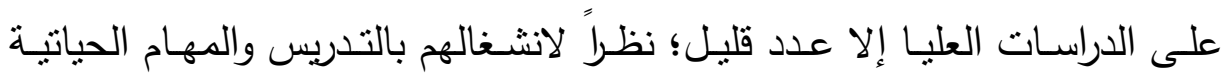

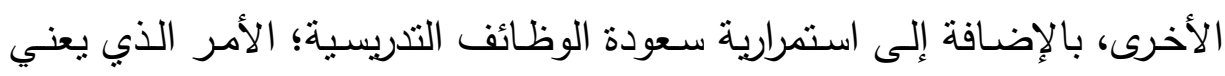
تعيين عدد كبير من المعلمين السعوديين حديثي التخرج في كثير من المدارس لاس السعودية.

جدول (r) :يوضح نوزيع العينة طبقا للوظيفة

\begin{tabular}{|c|c|c|}
\hline النسبة المئوية بالنسبة لإجمالي العينة & 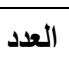 & 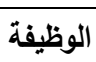 \\
\hline$\%$ \%,Y^ & V & مدير \\
\hline$\% 11, r V$ & $r \varepsilon$ & وكيل \\
\hline
\end{tabular}

DOI: $10.12816 / 0008988$ 


\begin{tabular}{|c|c|c|}
\hline$\% ৭, \wedge\urcorner$ & YI & معلم أول \\
\hline$\% \vee 0,09$ & 171 & معلم \\
\hline$\% 1 \ldots$ & & الإجمالي \\
\hline
\end{tabular}

اتضـح مـن خـلال الجـدول السـابق (Y) أن عـدد الذين اسـتجابوا مـن معلمي المدارس الثانوبـة بنين بالرباض قد اختلف طبقا لمتغير الوظيفة، حيث بلـن عدد

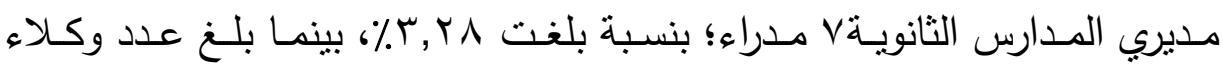

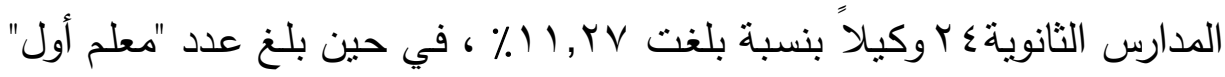

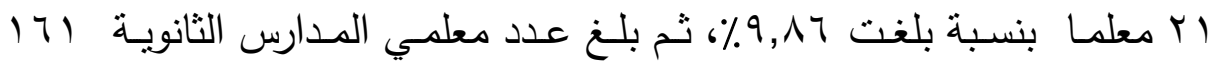
معلماً بنسبة بلغت 0,0 90 \% ، وهذه النتائج نتوافق إلى حد كبير مع نفس نتائج جدول (1)؛ لأن معظم الموجودين في المدارس هم المعلمون الذين يمثلون الكم الأكبر في المدرسة، بينما لا يوجد إلا مدير واحد في كل مدرسـة، وعدد قليل من الوكلاء لا يتعدى وكيلين في كل مدرسـة، كمـا أن عدد المعلمين الأوائل قليـل أيضا، مما جعل النسبة الأكبر من نصبي المعلمين.

\begin{tabular}{|c|c|c|}
\hline النسبة المئوية بالنسبة لإجمالي العينة & العدد الع & التخصص \\
\hline$\% \circ r, 01$ & $11 \%$ & 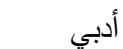 \\
\hline$\% \leqslant \vee, \leqslant Y$ & 1.1 & علمي \\
\hline$\% 1 \ldots$ & rit & الإجمالي \\
\hline
\end{tabular}

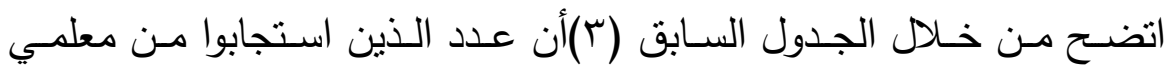
المدارس الثانوية بنين بالرياض قد اختلف طبقا لمتغير التخصص، حيث بلغ عدد

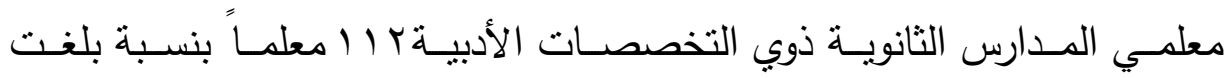

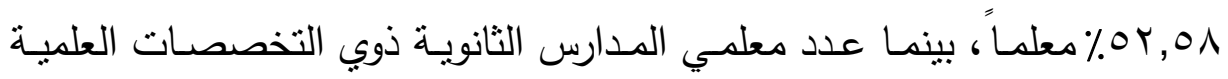

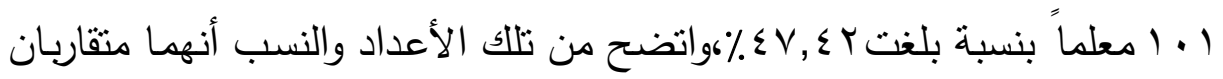
إلـى حـد مـا، وإن كـان عـدد معلمي التخصصـات الأدبيـة أكثر مـن معلمـي التخصصـات العلميـة؛وربما يرجـع السـبـ في ذلـك إلـى أنـهـ ربمـا يكـون عـدد 


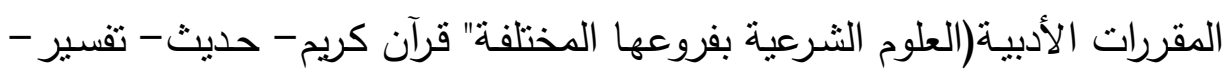

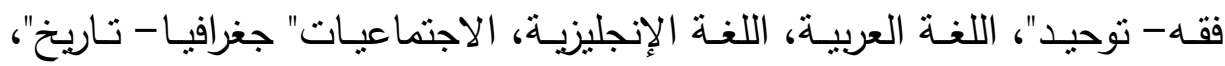
علوم إداريـة) أكثر من المقررات العلميـة (رياضيات، كيميـاء، فيزيـاء، أحياء )، وبالتالي ازداد عدد معلمي التخصصات الأدبية عن معلمي التخصصات العلمية. جدول (ع) يوضح توزيع العينة طبقا للخبرة

\begin{tabular}{|c|c|c|}
\hline النسبة المئوية بالنسبة لإجمالي العينة & العدد & الوظيفة الو \\
\hline$\% r \varepsilon, \vee \varepsilon$ & $v \varepsilon$ & أقل من ه سنوات \\
\hline$\% r, 1,1 r$ & 纟o & من ه - أقل من · ا سنوات \\
\hline$\% \curlyvee \leqslant, \wedge q$ & or & من · 1 - أقل من 10 سنوات \\
\hline$\% q, \wedge \uparrow$ & r) & من 10 - أقل من •r سنوات \\
\hline$\% q$, гq & r. & r r بأكثر \\
\hline$\% 1 .$. & rir & الإجمالي \\
\hline
\end{tabular}

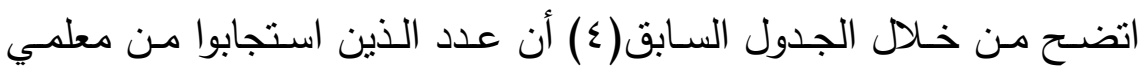

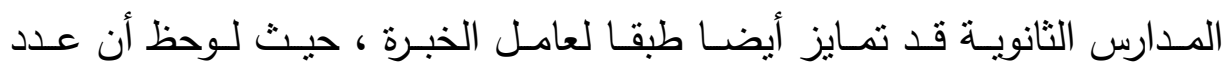

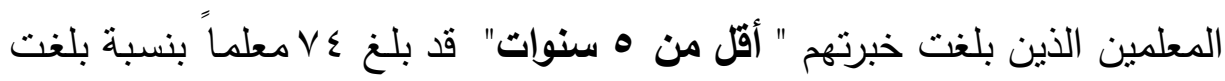

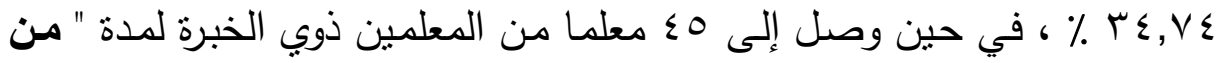

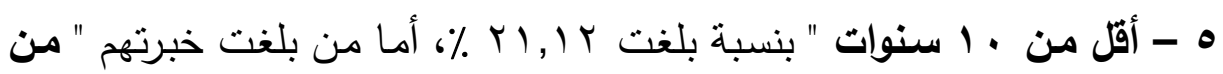

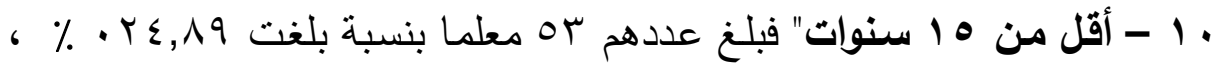

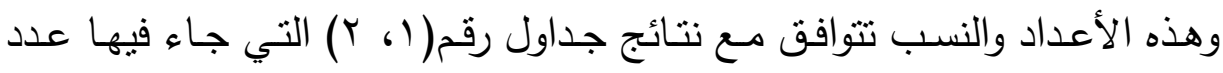
المعلمين أكثر من باقي الفئات الأخرى للمعلم؛ التي تدل على أنى أن النسبة الأكبر

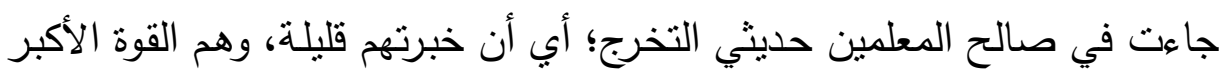
في أي مدرسة. ثالثا: أداة الدراسة مدربه في ضـوء مـا أمكـن مراجعتـهـ مـن الأدب التربـوي والدراسـات السـابقة المتعلقــة

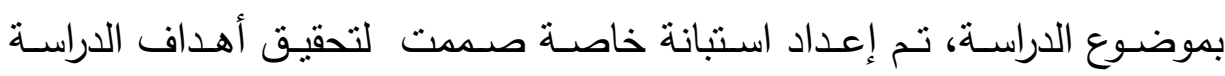
الحالية تدور حول ثلاثة محاور رئيسة على النحو التالي: 
1. أهمية أساليب تحديد الاحتياجات التدريبية للمعلمين.

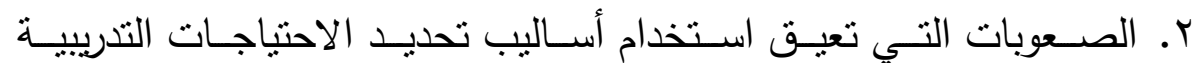
للمعلمين. r. فعالية أساليب تحديد الاحتباجات التدريبية للمعلمين. وصف الأداة

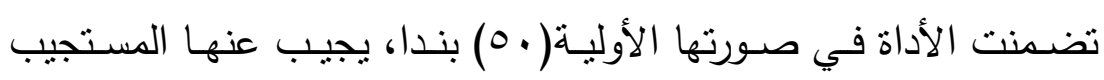

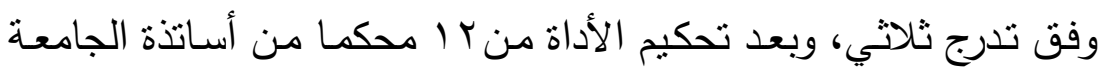

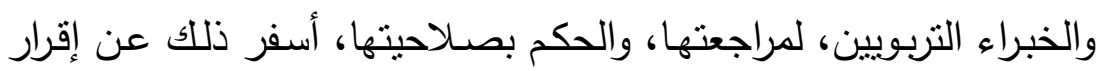

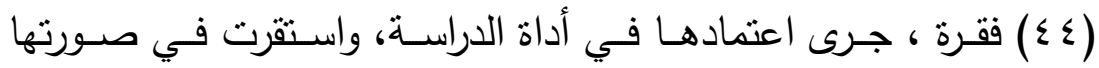

$$
\text { والنهائية. }
$$

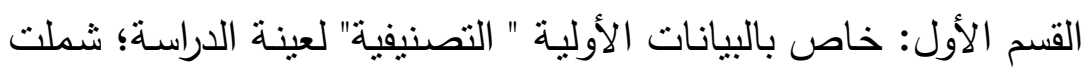

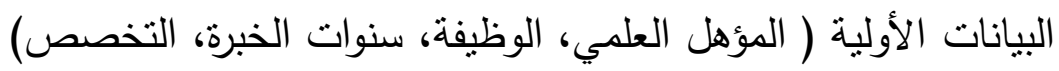

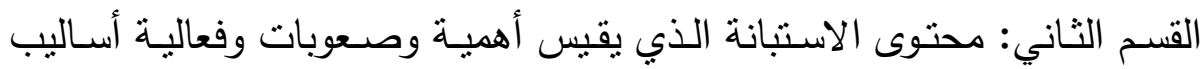

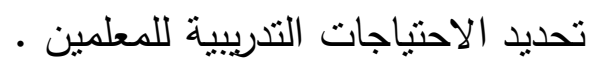

\begin{tabular}{|c|c|c|}
\hline عدد الفقرات & المحور & \\
\hline 0 & أهية أساليب تحديد الاحتياجات التنريبية للمعلمين & 1 \\
\hline $1 \varepsilon$ & 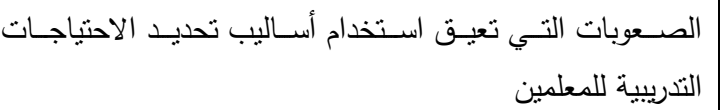 & r \\
\hline ro & فعالية أساليب تحديد الاحتياجات التنرييية للمعلمين & r \\
\hline$\varepsilon \varepsilon$ & الإجمالى & \\
\hline
\end{tabular}
جدول (0) يوضح توزيع محاور الدراسة وعدد عبارات قياس كل محور

رابعا: إجراءات تطبيق أداة الدراسة العمالى

ا ـ إعداد أداة الدراسة والتحقق من صدقها وثباتها. r. حصر أفراد مجتمع الدراسة، واختيار العينة العشوائية الدحددة. 
تصور مقترح لتفعيل أساليب تحديد الاحتياجات التدريبية د. هاني محمد يونس موسى

r. توزيـع الأداة على العينـة، وكيفيـة تعبئتهـا، والمهلـة المقدرة لـللك، وكيفيـة إعادتها للباحث.

ـ. فرز الاستمارات المعادة، واستبقاء غير الصالح منها، ثم إدخال الاستمارات الصالحة للحاسوب لتحليلها.

0. معالجة البيانات إحصـائيا واستخراج النتائج، وعرضـها ومناقتشتها والخروج بالتوصيات الملائمة. 


\section{خامسا: المعالجة الإحصائية}

اعتمد الباحث في خطة التحليل الإحصائي لبنود هذه الاستبانة على مجموعة من الإنس

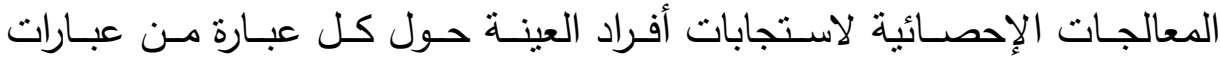
الاستبانة، وذللك من خلال برنامج الحزم الإحصائية للعلوم الاجتماعية الإصدار الثامن عشر (spss 18.0) ، وتم تقنين الاستبانة على النحو التالي :

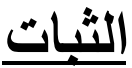

\section{أ- أثبات الاستبانة والمحاور:}

قـام الباحـث بتطبيـت معادلـة ألفـاــ كرونبـاخ؛ لحسـاب ثبـات الاسـنبانة ككل والمحاور الفرعية لها، وهذا يتضح من خلال استعراض نتائج الجدول التالي: جدول (7): يوضح ثبات الاسنبانة ككل والمحاور الفر عية باستخدام طريقة ألفا

\begin{tabular}{|c|c|c|c|}
\hline \multicolumn{2}{|c|}{ قيمة معامل الثبات } & المحور & م \\
\hline \multicolumn{2}{|c|}{$\cdot, \vee 19$} & 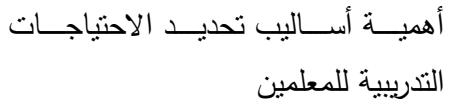 & 1 \\
\hline \multicolumn{2}{|c|}{$\cdot, \wedge \wedge q$} & تصديد الاحتباجات التدربيية للمعلمين استخدام أسـاليب & r \\
\hline \multirow{5}{*}{ الثبات الكلي } & $\cdot, \vee \vee$ & أولا أسـلوب المقـابلات الثخصـية مـع & \multirow{5}{*}{ 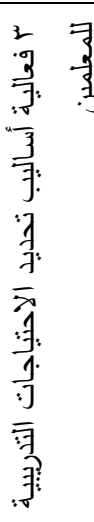 } \\
\hline & $\cdot, \wedge \leq \nearrow$ & ثانيا أسلوب قوائم الاحتياجات التكريبية & \\
\hline & $\cdot, \wedge 17$ & ثالثا أسلوب الزيارات الصفية & \\
\hline & 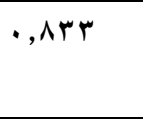 & مدير المدرسة أسلوب الاستقصاءات التي يجريها & \\
\hline & $\cdot, \wedge \vee \diamond$ & والمامســا أسـلوب الاعتمـاد على الخبـراء & \\
\hline \multicolumn{4}{|c|}{ 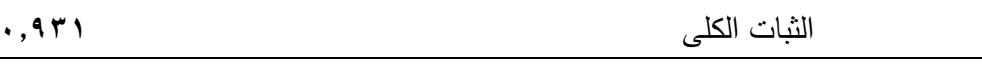 } \\
\hline
\end{tabular}

اتضـح من خلال استعراض نتائج جدول(7) ارتفاع قيم معاملات الثبات ألفا كرونباخ للمحاور الثلاثة وللاستبانه ككل. 
تصور مقترح لتفعيل أساليب تحديد الاحتياجات التدريبية د. هاني محمد يونس موسى

ب-ثبات عبارات المحاور

1- ثبات العبارات بطريقة ألفا كرونباخ

قام الباحث بحساب ثبات كل عبارة من عبارات المحاور الثلاثة؛ لقياس

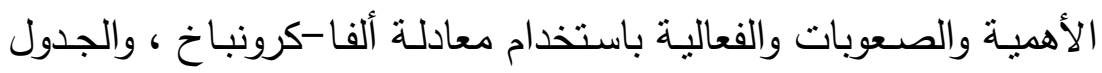

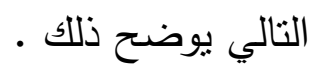

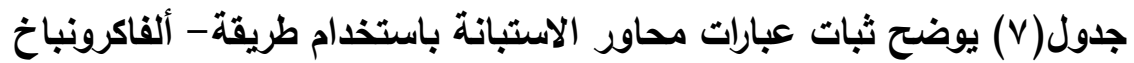

\begin{tabular}{|c|c|c|c|c|c|}
\hline \multicolumn{2}{|c|}{$\begin{array}{l}\text { أساليب تحديد الاحتياجات الثالث فعالية } \\
\text { التدريبية للمعلمين }\end{array}$} & \multicolumn{2}{|c|}{ المحور الثاني الصعويات التي تعيق ألتام التيب تحديد الاحتياجات } & \multicolumn{2}{|c|}{ 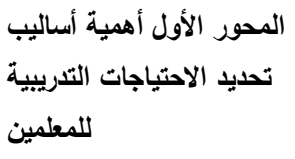 } \\
\hline قيمة الفا & 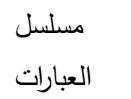 & قيمة الفا & مسلسل العبارات & قيمة الفا & مسلسل \\
\hline \multicolumn{2}{|c|}{ المقابلات الثخصية مع } & & & & \\
\hline$\cdot, v q r$ & 1 & $\cdot, \wedge \wedge \neg$ & 1 & טצד & 1 \\
\hline ש & r & $\cdot, \wedge \wedge \bullet$ & r & $\cdot, 7 V$. & r \\
\hline$\cdot, \vee \vee 17$ & r & $\cdot, \wedge \wedge 1$ & r & $\cdot$, IVI & r \\
\hline$\cdot, V Y Y$ & $\varepsilon$ & $\cdot, \wedge \wedge$. & $\varepsilon$ & $\cdot, r \wedge r$ & $\varepsilon$ \\
\hline$\cdot, v \leqslant \Lambda$ & 0 & $\cdot, \wedge \wedge \mathrm{r}$ & 0 & - , ror & 0 \\
\hline \multicolumn{2}{|c|}{$\begin{array}{l}\text { أسلوب قوائم الاحتياجات } \\
\text { التذريبية }\end{array}$} & •,A^r & 7 & & \\
\hline ـ & 1 & $\cdot, \wedge \vee q$ & v & & \\
\hline$\cdot, \wedge 1$ & r & $\cdot, \wedge \wedge \bullet$ & $\wedge$ & & \\
\hline$\cdot, \Lambda i r$ & r & $\cdot, \wedge \vee q$ & 9 & & \\
\hline$\cdot, \vee \vee 91$ & $\varepsilon$ & $\cdot, \wedge \vee \vee$ & 1. & & \\
\hline$\cdot, \wedge r r$ & 0 & $\cdot, \wedge \wedge \mu$ & 11 & & \\
\hline \multicolumn{2}{|c|}{ أسلوب الزيارات الصفية } & $\cdot, \wedge \wedge \mu$ & ir & & \\
\hline$\cdot, \vee \wedge \wedge$ & 1 & $\cdot, \wedge \wedge \mathrm{r}$ & ir & & \\
\hline$\cdot, \vee \vee \vee q$ & r & $\cdot, \wedge \vee \neg$ & $1 \varepsilon$ & & \\
\hline$\cdot, \vee \vee 79$ & r & & & & \\
\hline$\cdot, \vee \wedge$. & $\varepsilon$ & & & & \\
\hline$\cdot, \vee \wedge \vee$ & 0 & & & & \\
\hline \multicolumn{2}{|c|}{ أسلوب الاستقصاءات التي } & & & & \\
\hline
\end{tabular}

DOI: $10.12816 / 0008988$ 


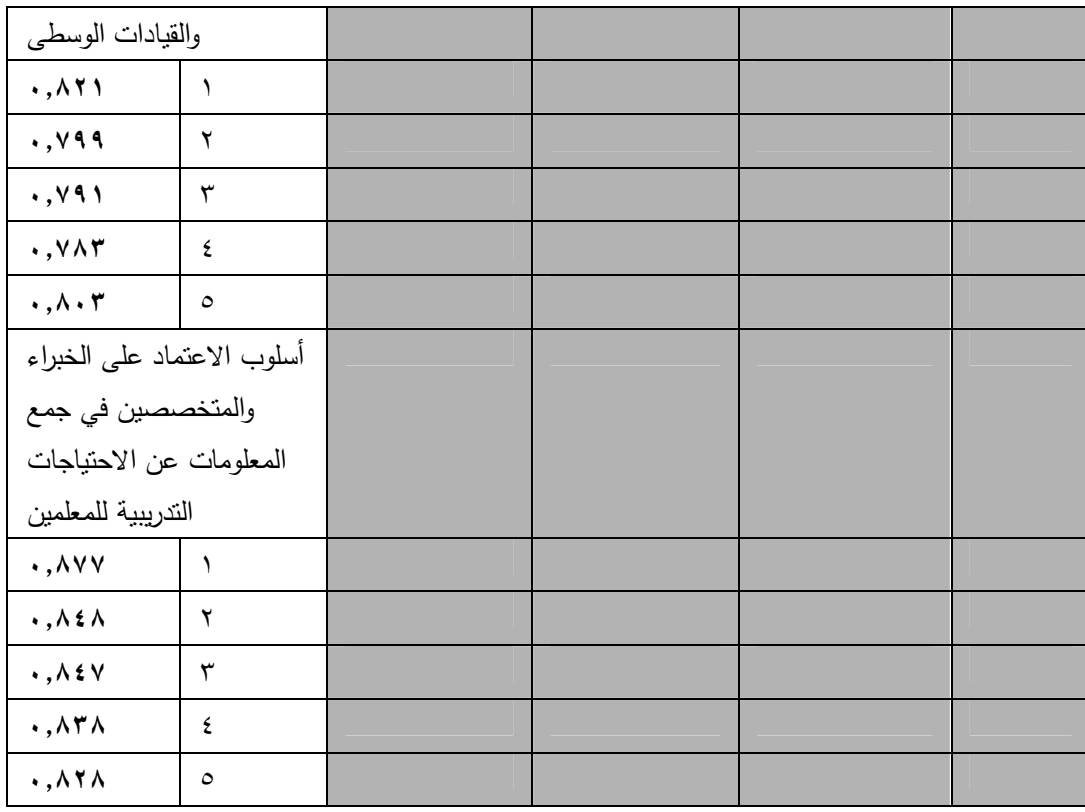

اتضح من خلال استعراض نتائج جدول(V) ارتفاع قيم معاملات الثبات لمحاور

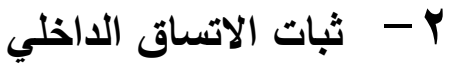

اسـتخدم الباحث معادلـة بيرسـون لحسـاب قيمـة معامـل ارتبـاط درجـة كل عبـارة

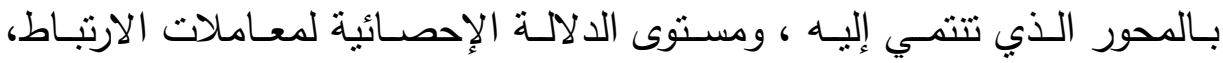
ويتضح ذللك من خلال استعراض الجدول الثالي: جدول (^): يوضح قيمة معامل ارتباط بيرسون ومستوى الدلالة الإحصائية للمحور الأول

\begin{tabular}{|c|c|c|c|}
\hline 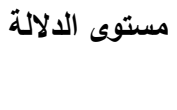 & قالارتباط معامل & عبارات المحور الأول & م \\
\hline$\cdot, \cdot 1$ & $\cdot, \curlyvee \wedge$ & المقابلات الثخصية مع المعلمين. & 1 \\
\hline$\cdot, \cdot 1$ & $\cdot, 7 \vee 9$ & قوائم الاحتياجات التذريبية للمعلمين. & r \\
\hline$\cdot, \cdot 1$ & $\cdot, T \vee \leq$ & الزيارات الصفية لملاحظة أداء المعلم & r \\
\hline$\cdot,+1$ & $\cdot, 10 \wedge$ & الالوسطى & $\varepsilon$ \\
\hline$\cdot, \cdot 1$ & $\cdot, \vee \vee r$. & الاعتمــاد علـى الخبـراء والمتخصصـين فـي جمـع & 0 \\
\hline
\end{tabular}


تصور مقترح لتفعيل أساليب تحديد الاحتياجات التدريبية د. هاني محمد يونس موسى

\begin{tabular}{|l|l|l|l|}
\hline & & & \\
\hline
\end{tabular}

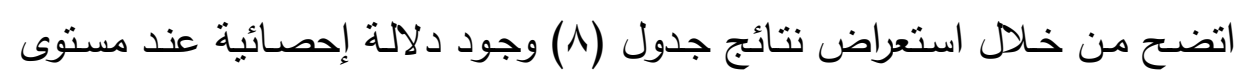

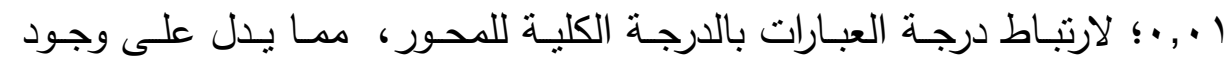
تجانس داخلي للمحور •

جـدول(9): يوضـح قيمـة معامـل ارتبـاط بيرسـون ومسـتوى الدلالــة الإحصـائية للمحور الثاني الصعوبات التي تعيق استخدام أساليب تحديد الاحتياجات التدريبية

\begin{tabular}{|c|c|c|c|}
\hline 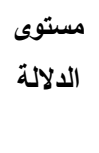 & قبمة & عبارات المحور الثاني & b \\
\hline$\cdot,+1$ & $\cdot, \infty \bullet$ & ضعف قناعة بعض مديري المدارس بأهمية تحديد الاحتياجات التدريبية للمعلمين. & 1 \\
\hline$\cdot, \cdot 1$ & $\cdot, 0 \vee 1$ & صعبية توفر الوقت الكافي لدى منسق التدريب بالمدرسة لتحديد الاحتياجـات & r \\
\hline$\cdot, \cdot 1$ & $\cdot, 7 \leq \cdot$ & الاحتقار مسئولي التدريب بالمدارس إلى الخبرة في تطبيق الأساليب المختلفة لتحديد & r \\
\hline$\cdot, \cdot 1$ & $\cdot, 7 \vee 9$ & حلهة اهتمام مديري المدارس بتحليل المشكلات التي تواجه المدرسة وترتيب أولويات & $\varepsilon$ \\
\hline$\cdot,+1$ & 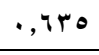 & عدم الرجوع إلى الوصف الوظيفي للمعلم وتحديد مهامه بدقة ووضوح. & $\circ$ \\
\hline$\cdot,+1$ & $\cdot, 7 \cdot 7$ & الافتقار إلى المعلومات المتصلة بالمؤشرات الموضوعية لأداء المعلمين بالمدارس. & 7 \\
\hline$\cdot, \cdot 1$ & $\cdot, 790$ & ضعف إثرالك المعلمين في تحديد احتياجاتهم التدريبية. & v \\
\hline$\cdot, \cdot 1$ & $\cdot, 07 r$ & الاعتدريبية للمعلمين. فقط- على المـيرين أو المعلمين الأوائل في تحديــ الاحتياجـات & $\wedge$ \\
\hline$\cdot,+1$ & $\cdot, \Upsilon \wedge \uparrow$ & ضعف التتسيق بين المدارس وادارة التذريب والنطوير المهني & 9 \\
\hline$\cdot,+1$ & $\cdot, \vee \vee Y ५$ & ضعف العناية بتحليل المشكلات التي يواجهها المعلمون وترتيب أولويات حلها. & $1 \cdot$ \\
\hline$\cdot,+1$ & $\cdot, 7 \cdot \varepsilon$ & بتنفيذ البرامج التدريبية المدة الزمنية المخصصة لحصر وتحديد الاحتياجات التدريبية. والتعجل & 11 \\
\hline$\cdot,+1$ & $\cdot, \operatorname{tra}$ & ضعف استخدام التقنيات والأجهزة الحديثة في تحديد الاحتياجات التدرييية. & ir \\
\hline$\cdot,+$, & $\cdot$, o & ضعف التتسيق بين المشرف التربوي وادارة المدرسة. & ir \\
\hline$\cdot,+1$ & $\cdot, \mathrm{v} r \mathrm{O}$ & عدم القيام ببحوث ميدانية لمعرفة مشكلات تحديد الاحتباجات التدربيية للمعلمين. & $1 \leqslant$ \\
\hline
\end{tabular}

اتضح من خلال استعراض نتائج جدول (9) وجود دلالة إحصائية عند مستوى

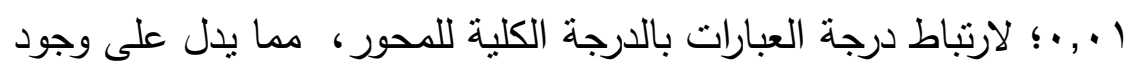

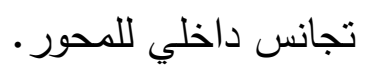


جدول ( • (1): يوضتح قيمة معامل ارتباط بيرسون ومستوى الدلالة الإحصائية للمحور الثالث فعالية أساليب تحديد الاحتياجات التدربيية للمعلمين (أسلوب

المقاباتات الثخصية مع المعلمين)

\begin{tabular}{|c|c|c|}
\hline 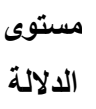 & قالارتباط معامل & عبارات المحور الثالث \\
\hline$\cdot, \cdot 1$ & $\cdot, 71 \wedge$ & الكثف عن اتجاهات المعلمين تجاه البرامج التدريبية. \\
\hline$\cdot, \cdot+$ & $\cdot, \mathrm{V} \backslash \mathrm{V}$ & تحديد أوجه القصور في أداء المعلم. \\
\hline$\cdot, \cdot 1$ & $\cdot, \Lambda \mid r$ & خلال البرامج التنريبية. \\
\hline$\cdot, \cdot 1$ & $\cdot, \vee \wedge \uparrow$ & التدريية. \\
\hline$\cdot, \cdot 1$ & $\cdot, \mathrm{V} \leq \leq$ & تصعيم البرامج التدريييـة التـي تلبي الاحتياجـات التدريبيـة \\
\hline
\end{tabular}

اتضح من خلال استعراض نتائج جدول ( • () وجود دلالة إحصائية عند مستوى ا ·, •؛ لارتباط درجة العبارات بالدرجة الكلية للمحور، ما بدل على وجود تجانس داخلي للمحور •

جدول(1) يوضح قيمة معامل ارتباط بيرسون ومستوى الدلالة الإحصائية للمحور الثالث فعالية أساليب تحديد الاحتياجات التذربيية للمعلمين (أسلوب قوائم الاحتياجات

التدربيية)

\begin{tabular}{|c|c|c|c|}
\hline 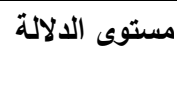 & قيمة معامل & عبارات المحور الثالث & b \\
\hline$\cdot,+1$ & $\cdot, \vee \vee \wedge$ & ترامج التدريب. المعلومات والمعارف التي ينبغي أن تتضمنها & 1 \\
\hline$\cdot,+1$ & $\cdot, \vee \vee 9 \vee$ & كثأداء وظائفهم بفعارات التي ينبغي تتميتها لدى المعلمين & r \\
\hline$\cdot,+1$ & $\cdot, \wedge \cdot 1$ & تحديد الاتجاهات التي ينبغي تتميتها لدى المعلمين. & r \\
\hline$\cdot,+1$ & $\cdot, \wedge \leq 0$ & 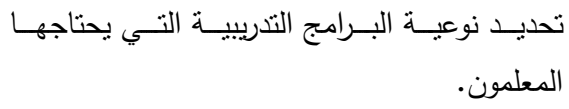 & $\varepsilon$ \\
\hline$\cdot,+1$ & ., $\vee 79$ & تصميم البرامج التدريبية الملائمة للمعلمين. & 0 \\
\hline
\end{tabular}


اتضح من خلال استعراض نتائج جدول (1 (1)وجود دلالة إحصائية عند مستوى

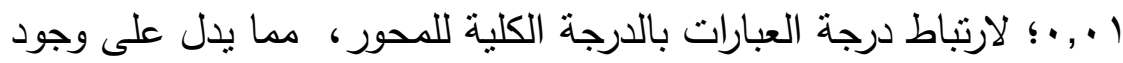

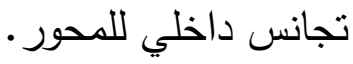
جدول (Y I ) يوضح قيمة معامل ارتباط بيرسون ومستوى الدلالة الإحصائية للمحور الثالث فعالية أساليب تحديد الاحتباجات التدريبية للمعلمين (أسلوب الزيارات الصفية)

\begin{tabular}{|c|c|c|c|}
\hline مستوى الالالة & قيمة معامل الارتباط & عبارات المحور الثالث & م \\
\hline$\cdot,+1$ & $\cdot, \vee \vee$ & تخطيط البرامج التدريبية التي تعالج سلبيات سلوكيات & 1 \\
\hline$\cdot,+1$ & $\cdot, \mathrm{V} \bullet \mathrm{Y}$ & 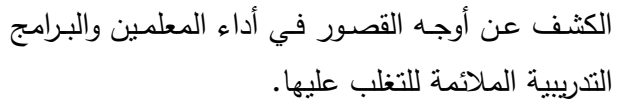 & r \\
\hline$\cdot, \cdot 1$ & $\cdot, \vee \wedge 1$ & تحديد نوعية التدريب التي يحتاجها المعلمون. & r \\
\hline$\cdot,+1$ & $\cdot, \vee \vee q$ & ملاعمة برامج التدريب للاحنياجات الفعلية للمعلمين & $\varepsilon$ \\
\hline$\cdot, \cdot 1$ & $\cdot, \mathrm{V} \leq \cdot$ & 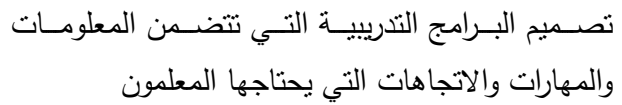 & 0 \\
\hline
\end{tabular}

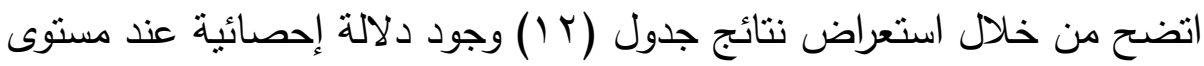

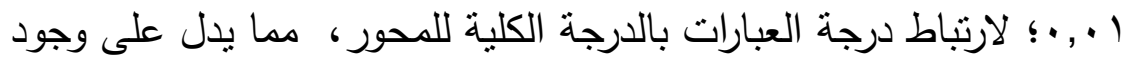

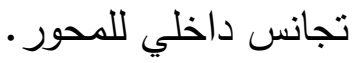
جدول (س ا ) يوضح قيمة معامل ارتباط بيرسون ومستوى الدلالة الإحصائية للمحور

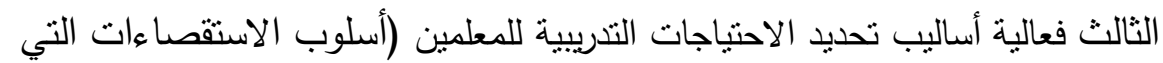
يجريها مدير الددرسة والقيادات الوسطى)

\begin{tabular}{|c|c|c|c|}
\hline 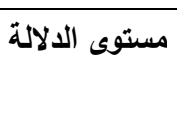 & قيمة معامل & عبارات المحور الثالث & s \\
\hline$\cdot,+1$ & $\cdot, \mathrm{V} \backslash \mathrm{r}$ & معرفة وضوح أهداف المدرسة لدى المعلمين. & 1 \\
\hline$\cdot, \cdot 1$ & $\cdot, \mathrm{\vee} \vee \mathrm{O}$ & معرفة نوع التدريب الذي يحتاجه المعلمون. & r \\
\hline., .1 & $\cdot, \vee \vee$ & الكثثف عن البرامج التذريبية التي تشهم في تحسين الأداء & r \\
\hline$\cdot,+1$ & $\cdot, \wedge \backslash \wedge$ & تصميم البرامج التدريبية للمعلمين بأسلوب علمي. & $\varepsilon$ \\
\hline$\cdot, .+1$ & $\cdot, \vee \vee \vee q$ & تحديد روية المعلمين الذانية لاحتياجاتهم التذريبية. & o \\
\hline
\end{tabular}


اتضتح من خلال استعراض نتائج جدول (T I) وجود دلالة إحصائية عند مستوى

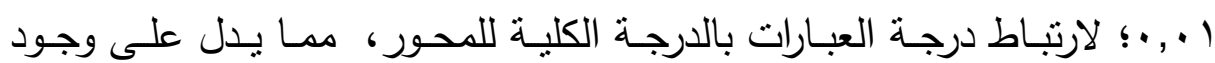
تجانس داخلي للمحور • جدول (ع ا ) يوضح قيمة معامل ارتباط بيرسون ومستوى الدلالة الإحصائية للمحور الثالث فعالية أساليب تحديد الاحتياجات التدريبية للمعلمين (أسلوب الاعتماد على الخبراء والمتخصصين في جمع المعلومات عن الاحتباجات التدريبية للمعلمين)

\begin{tabular}{|c|c|c|c|}
\hline 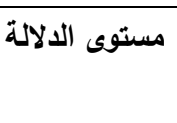 & قيمة معامل & عبارات المحور الثالث & م \\
\hline$\cdot, \cdot 1$ & $\cdot, \vee \curlyvee \wedge$ & للمعلميم بـرامج تدريييـة تنتاسب مـع الاحتياجـات الفعليـة & 1 \\
\hline$\cdot, \cdot 1$ & $\cdot, \wedge r \cdot$ & كثف جوانب الضعف التي يمكن التغلب عليها من خلال & r \\
\hline$\cdot, \cdot 1$ & $\cdot, \wedge Y_{1}$ & تخطيط برامج تدريبية تلبي الاحتياجات الفعلية للمعلمين. & r \\
\hline$\cdot, \cdot 1$ & $\cdot, \wedge \leq \leqslant$ & تخطيط برامج تدريبية تتناسب مع قدرات المتدربين & $\varepsilon$ \\
\hline$\cdot,+1$ & $\cdot, \wedge \uparrow \wedge$ & تصميم برامج تدرييية ابتكارية & 0 \\
\hline
\end{tabular}

اتضح من خلال استعراض نتائج جدول (ع ()) وجود دلالة إحصائية عند مستوى

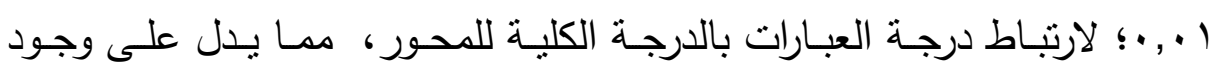
تجانس داخلي للمحور •

\section{-}

أ- - مدق المحكمين

عرضت الاستبانة في صورتها الأولية على ا ا محكماً من أساتذة كليات التربية في تخصصات نربوية منتوعة (تربية - علم نفس - صحة نفسية- مناهج وطرق تـدريس)؛ لمراجعتهـا، والحكم بصــلاحيتها؛ للتعـرف على وجهـة نظـرهم حـول الاستبانة من حيث مدى فعاليتها في تحقيق أهدافها، ومدى قياسها لما وضعت له، فأبدى بعض المحكمين ضرورة إجراء بعض التغييرات بالحذف، أو الإضـافة، أو إعادة الصياغة، حتى استقر الأمر على الصورة النهائية للاستبانة . 


$$
\text { ب- صدق التجانس الداخلي }
$$

قام الباحث بحساب صدق التجانس الداخلي من خلال حساب قيمة معامل ارتباط

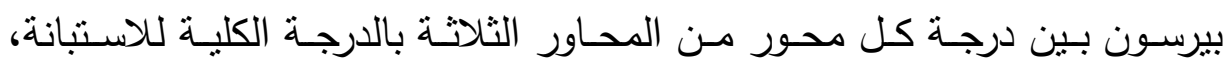
وحساب مستوى الدلالة، ، ويتضح هذا من خلال الجدول التالي : جدول (10) يوضح قيمة معامل ارتباط بيرسون ومسنوى الدلالة الإحصائية لمحاور الاستبانة

\begin{tabular}{|c|c|c|c|c|}
\hline مستوى الدلالة & قيمة معامل & \multicolumn{2}{|l|}{ 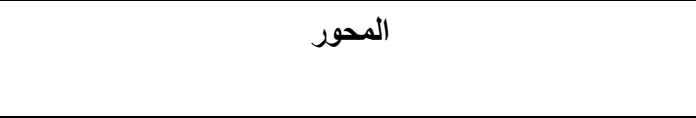 } & م \\
\hline$\cdot, \cdot 1$ & $\cdot, T \vee \cdot$ & \multicolumn{2}{|c|}{ أهمية أساليب تحديد الاحتياجات التربيية للمعلمين } & 1 \\
\hline$\cdot,+1$ & $\cdot, 791$ & \multicolumn{2}{|c|}{ 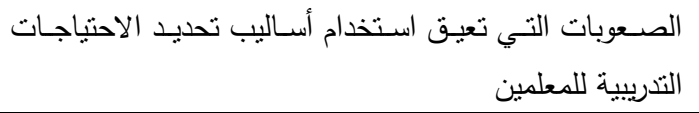 } & $r$ \\
\hline$\cdot,+1$ & $\cdot, V Y V$ & أولا أسلوب المقابلات الشخصية مع المعلمين & \multirow{5}{*}{ 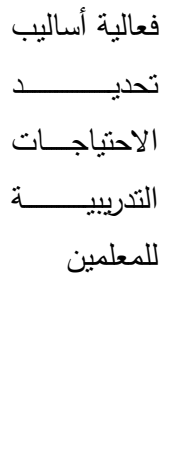 } & \multirow[t]{5}{*}{ r } \\
\hline$\cdot,+1$ & $\cdot, 77 \leq$ & ثانيا أسلوب قوائم الاحتياجات التدريبية & & \\
\hline$\cdot, \cdot 1$ & $\cdot, V \leq \neg$ & ثالثا أسلوب الزيارات الصفية & & \\
\hline$\cdot, \cdot 1$ & $\cdot, v 01$ & المدرسة أسلوب الاستقصاءات التي يجربها مدير & & \\
\hline$\cdot,+1$ & $\cdot, 740$ & 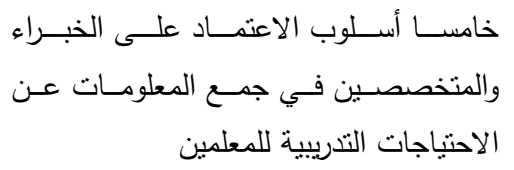 & & \\
\hline
\end{tabular}

اتضح من خلال استعراض نتائج جدول ( • ( ) وجود دلالة إحصائية عند مستوى التصرئين

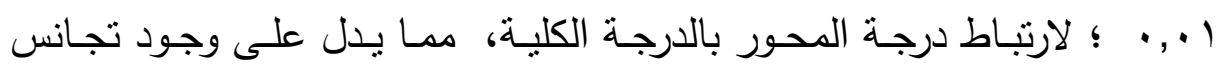
داخلي للاستبانة. 


\section{سادسا : تفسير نتائج الدراسة ومناقشتها}

تم تحليل وتفسير نتائج الدراسة الميدانية؛ للتعرف على وجهة نظر معلمي المرحلة

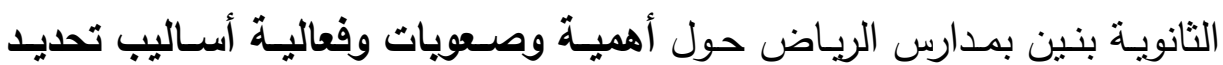

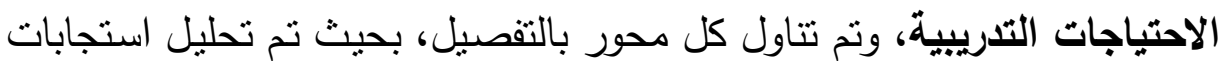

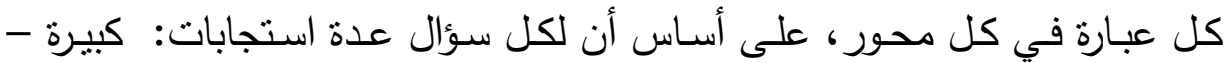

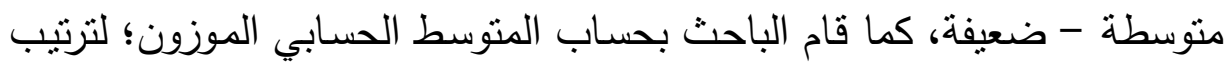

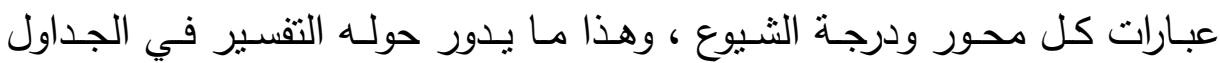
التالية :

1 - عرض نتـائج المحور الأول المتعلقة بأهميـة أسـاليب تحديـ الاحتياجـات

\section{التشريية}

جدول (7 1 ) يوضح التكرارات والنسب المئوية والمتوسط الموزون والانحراف المعياري ودرجة الموافقة وترتيب العبارات للمحور الأول

\begin{tabular}{|c|c|c|c|c|c|c|c|c|}
\hline \multirow{2}{*}{ بترتي } & \multirow{2}{*}{ الانحراف } & \multirow{2}{*}{ المستوسط المورجي } & \multicolumn{3}{|c|}{ درجة الموافقة } & \multirow{2}{*}{ تكرار } & \multirow[t]{2}{*}{ العبارات } & \multirow[t]{2}{*}{ م } \\
\hline & & & ضعيفة & متوسطة & كبيرة & & & \\
\hline 2 & .62611 & $\begin{array}{c}2.5258 \\
\text { كبيرة }\end{array}$ & $\begin{array}{l}10 \\
\% \vee\end{array}$ & $\begin{array}{c}\text { vI } \\
\% r r, r\end{array}$ & $\begin{array}{l}\text { IYV } \\
\% \circ 9,7\end{array}$ & s & المقـابلات الشخصية مـع & 1 \\
\hline 1 & .63997 & $\begin{array}{c}2.5446 \\
\text { كبيرة }\end{array}$ & $\begin{array}{l}\text { IV } \\
\% \wedge,\end{array}$ & $\begin{array}{c}\text { \% } \\
\% \text { rq, }\end{array}$ & אוזו & 乌 & 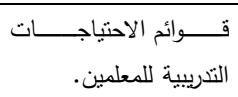 & r \\
\hline 3 & .62505 & $\begin{array}{c}2.4554 \\
\text { كبيرة }\end{array}$ & $\begin{array}{c}10 \\
\% \vee\end{array}$ & $\begin{array}{c}\wedge\urcorner \\
\% \varepsilon, \varepsilon\end{array}$ & $\begin{array}{l}\text { I r } \\
\text { \%०r, } 7\end{array}$ & 与 & 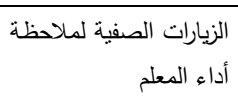 & r \\
\hline 5 & .64534 & $\begin{array}{c}2.3474 \\
\text { كبيرة }\end{array}$ & $\begin{array}{c}r \cdot \\
\% q, \varepsilon\end{array}$ & $\begin{array}{c}99 \\
\% \leq 7,0\end{array}$ & $\begin{array}{c}q \leq \\
\% \leq \leq, 1\end{array}$ & $\begin{array}{l}5 \\
\%\end{array}$ & 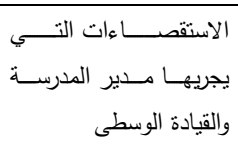 & $\varepsilon$ \\
\hline 4 & .71359 & $\begin{array}{c}2.3756 \\
\text { كبيرة }\end{array}$ & $\begin{array}{l}r q \\
1 r, 7 \\
\%\end{array}$ & $\begin{array}{c}\text { vo } \\
\% \text { ro, r }\end{array}$ & $\begin{array}{c}1.9 \\
\% 01, r\end{array}$ & 5 & 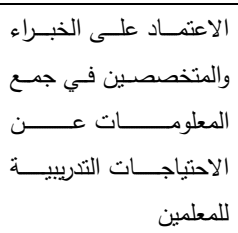 & 。 \\
\hline
\end{tabular}




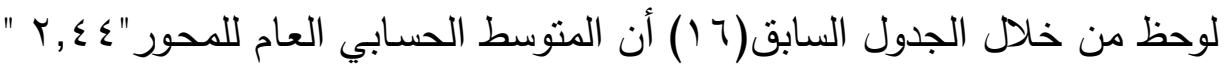
بدرجة موافقة " كبيرة" والانحراف المعياري العام "• † , · "، وهذا يظهر الأهمية الكبيرة لأسـاليب تحديد الاحتياجات التدريبية، كما يظهر اتفاق العينة على الدور

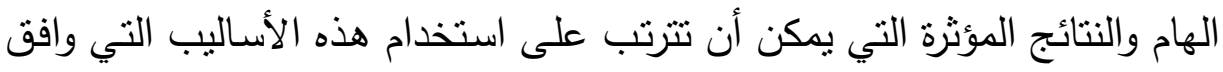

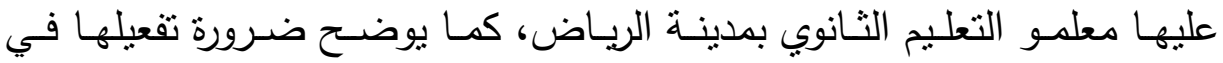

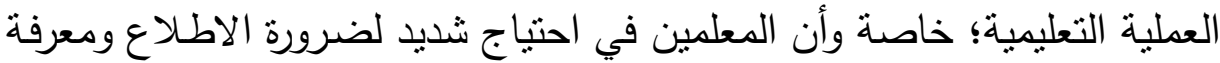

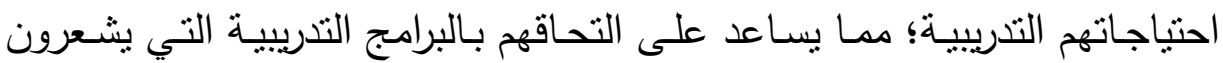

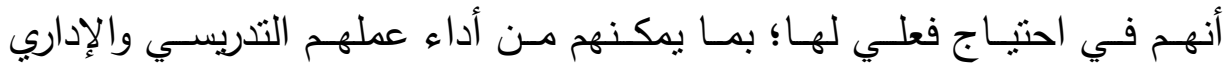
والإشرافي في المدارس التي يعملون بها.

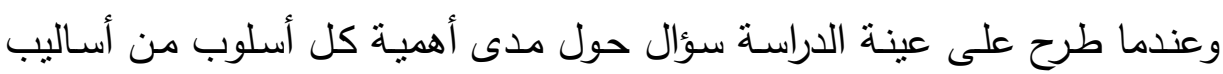

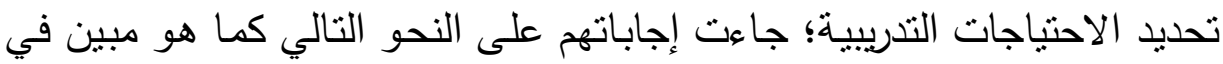
الجدول السابق(7 (1) فقد حصل أسلوب " قوائم الاحتياجات التدريبية للمعلمين "

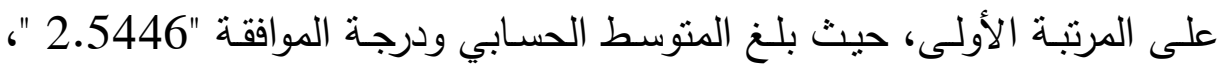
وربما يرجع السبب في ذلك إلى اعتماد هذا الأسلوب على الإجابات الجاهزة وهي

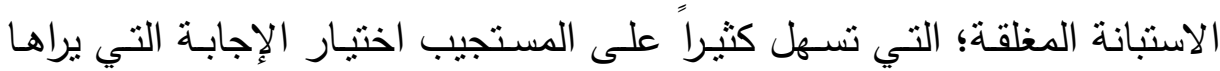

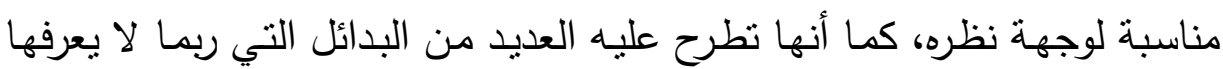

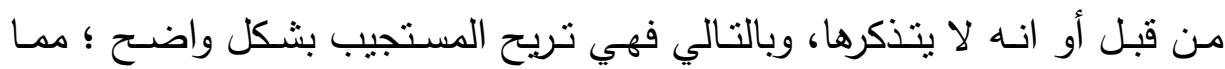
جعلها في مقدمة اختياراته. ثم تلاه في المرتبة الثانية أسلوب " المقابلات الثخصية مـع المعلمين " حيث بلـغ المتوسط الحسـابي ودرجـة الموافقة "2.5258 "، وهو ترتيب متقدم أيضـا، وقريب من ترتيب الأسلوب السابق، وربما يرجع السبب في ذلك إلى أن المقابلة

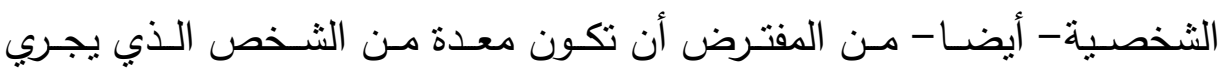

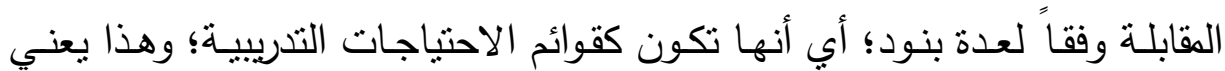

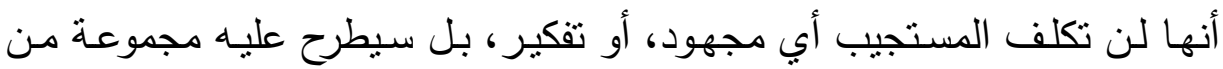


الأستلة والبـدائل المتاحـة، ومـا عليـه إلا أن يختار أحدها، وهي بـذلك تعد أهـراً مريحاً؛ مما جعلها تحظى بالمرتبة الثانية. وجاء في المرتبة الثالثة أسلوب" الزيارات الصفية لملاحظة أداء المعلم " حيث

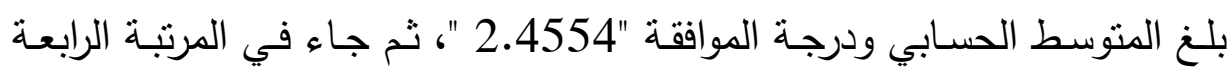
قبل الأخيرة أسلوب " الاعتمـاد على الخبراء والمتخصصين في جمع المعلومـات

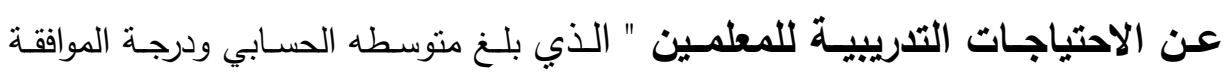

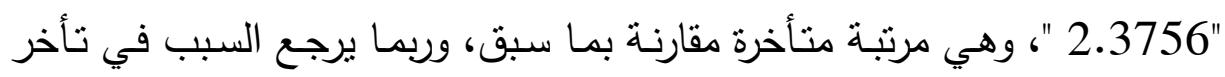
هذين الأسلوبين للمرتبتين الثالثة والرابعـة إلى أن المعلم يقلق من أيسة زيـارة يقوم

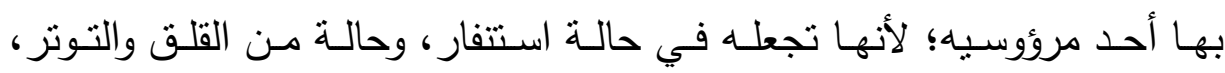
وبالتالي فالزيارة الصفية - دائما - تعني وجود تعليمات من الرئيس للمرؤوس،

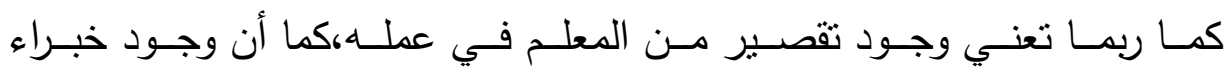

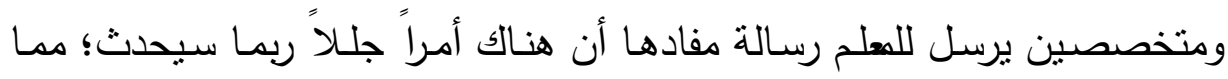

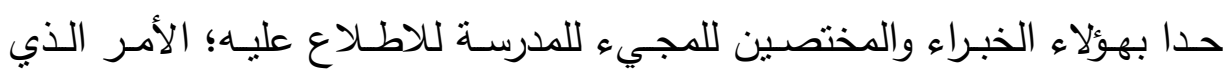

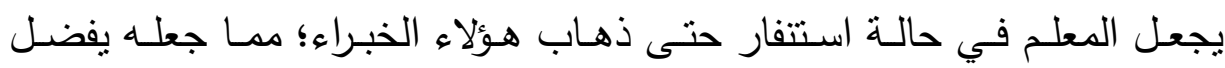

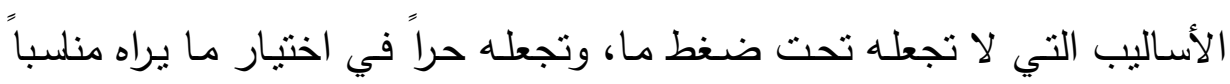

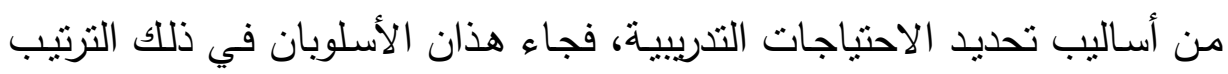
المتأخر ، ولم يحظ بموافقة كبيرة لدى المعلمين.

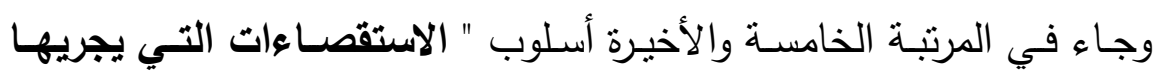
مدير المدرسـة والقيادة الوسطى " حيث بلغ المتوسط الحسابي ودرجة الموافقة " 2.3474"، وقد جاءت في ذلك الترتيب المتأخر ، لأن المعلم لا يميل بشكل كبير

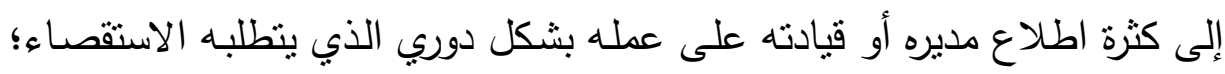

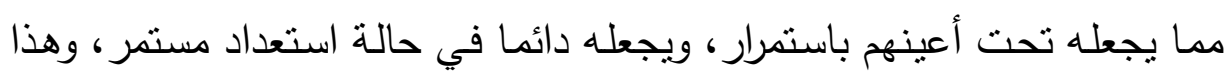

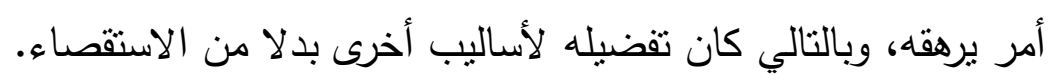


تصور مقترح لتفعيل أساليب تحديد الاحتياجات الترييية د. هاني محمد يونس موسى

ץ - عرض نتائج المحور الثاني المتعلقة بالصـويات التـي تعيق استخدام أساليب تحديد الاحتياجات التدريبية للمعلمين.

جدول (IV يوضح التكرارات والنسب المئوية والمتوسط الموزون والانحراف المعياري ودرجة الموافقة وترتيب العبارات للمحور الثاني الصعويات التي تعيق استخدام أساليب تحديد الاحتياجات التدريبية للمعلمين

\begin{tabular}{|c|c|c|c|c|c|c|c|c|}
\hline \multirow[t]{2}{*}{ الترتيب } & \multirow{2}{*}{ الانعيلاري } & \multirow{2}{*}{ الحسابي } & \multicolumn{3}{|c|}{ درجة الموافقة } & \multirow{2}{*}{ نكرية } & \multirow[t]{2}{*}{ العبارات } & \multirow[t]{2}{*}{ p } \\
\hline & & & ضعيفة & متوسطة & كبيرة & & & \\
\hline 4 & .67601 & $\begin{array}{l}2.3568 \\
\text { كبيرة }\end{array}$ & $\begin{array}{l}r \leq \\
\% \backslash 1, r\end{array}$ & $\begin{array}{l}\wedge 9 \\
\% \leqslant 1, \wedge\end{array}$ & $\begin{array}{c}1 \ldots \\
\% \leqslant \pi, q\end{array}$ & \% s & 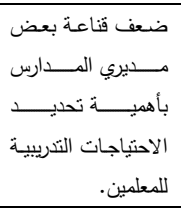 & 1 \\
\hline 8 & .63664 & $\begin{array}{l}2.3146 \\
\text { متوسطة }\end{array}$ & $\begin{array}{l}r \cdot \\
\% १, \varepsilon\end{array}$ & $\begin{array}{l}1.7 \\
\% \leqslant 9, \wedge\end{array}$ & $\begin{array}{l}\text { Av } \\
\% \leq \cdot,\end{array}$ & $\begin{array}{l}5 \\
\%\end{array}$ & 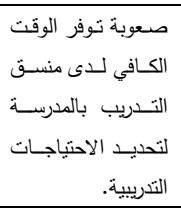 & $r$ \\
\hline 7 & .66691 & $\begin{array}{l}2.3192 \\
\text { منوسطة }\end{array}$ & $\begin{array}{l}r \leq \\
\% \backslash 1, r\end{array}$ & $\begin{array}{l}\text { 9v } \\
\% \leqslant 0,0\end{array}$ & $\begin{array}{l}q r \\
\% \leqslant r, r\end{array}$ & $\begin{array}{l}\text { s } \\
\%\end{array}$ & 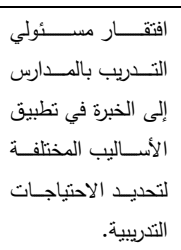 & $r$ \\
\hline 12 & .67276 & $\begin{array}{l}2.2911 \\
\text { منوسطة }\end{array}$ & $\begin{array}{l}r y \\
\% \backslash r, r\end{array}$ & $\begin{array}{l}99 \\
\% \leqslant 7,0\end{array}$ & $\begin{array}{l}M \\
\% \leqslant 1, r\end{array}$ & $\begin{array}{l}5 \\
\%\end{array}$ & 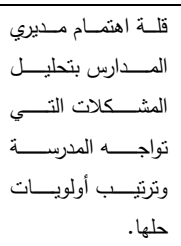 & $\varepsilon$ \\
\hline 14 & .62089 & $\begin{array}{l}2.2300 \\
\text { متوسطة }\end{array}$ & $\begin{array}{l}r r \\
\% 1 \cdot, r\end{array}$ & $\begin{array}{l}\text { rr. } \\
\% 07, r\end{array}$ & $\begin{array}{l}\text { VI } \\
\% r r, r\end{array}$ & $\begin{array}{l}5 \\
\%\end{array}$ & 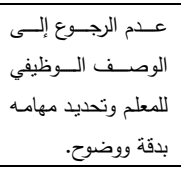 & 0 \\
\hline 13 & .61850 & $\begin{array}{l}2.2817 \\
\text { متوسطة }\end{array}$ & $\begin{array}{l}19 \\
\% \wedge, 9\end{array}$ & $\begin{array}{l}110 \\
\% \circ \leqslant, .\end{array}$ & $\begin{array}{l}v q \\
\% r v, 1\end{array}$ & $\begin{array}{l}5 \\
\%\end{array}$ & 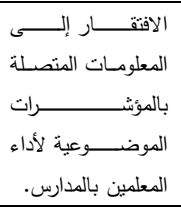 & 7 \\
\hline 5 & .72876 & $\begin{array}{l}2.3521 \\
\text { كبيرة }\end{array}$ & $\begin{array}{l}\text { rr } \\
\% 10, .\end{array}$ & $\begin{array}{l}Y \varepsilon \\
\% r \varepsilon, Y\end{array}$ & $\begin{array}{l}1 \cdot V \\
\% 0 \cdot, r\end{array}$ & $\begin{array}{l}5 \\
\%\end{array}$ & 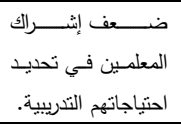 & v \\
\hline
\end{tabular}


مجلة الدراسات التريوية والانسانية ـ كلية التربية . جامعة دمنهور ـ المجلد السادس - العدد الثانى - لسنة ؛ ا ب

\begin{tabular}{|c|c|c|c|c|c|c|c|c|}
\hline \multirow[t]{2}{*}{ الترتيب } & \multirow{2}{*}{ الانحراف } & \multirow{2}{*}{ المسابي } & \multicolumn{3}{|c|}{ درجة الموافقة } & \multirow{2}{*}{ نكئ } & \multirow[t]{2}{*}{ العبارات } & \multirow[t]{2}{*}{ م } \\
\hline & & & ضعيفة & متوسطة & كبيرة & & & \\
\hline 3 & .68058 & $\begin{array}{l}2.3803 \\
\text { كبيرة }\end{array}$ & $\begin{array}{l}r \leq \\
\% \backslash 1, r\end{array}$ & $\begin{array}{l}\wedge \varepsilon \\
\% \text { \%, }\end{array}$ & $\begin{array}{l}1.7 \\
\% \leq 9, r\end{array}$ & $\begin{array}{l}5 \\
\%\end{array}$ & 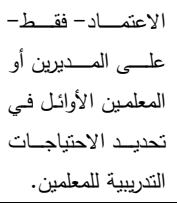 & $\wedge$ \\
\hline 1 & .65383 & $\begin{array}{l}2.4460 \\
\text { كبيرة }\end{array}$ & $\begin{array}{l}19 \\
\% \wedge, 9\end{array}$ & $\begin{array}{l}\text { A. } \\
\% r v, T\end{array}$ & $\begin{array}{l}11 \leq \\
\% \text { or,o }\end{array}$ & $\begin{array}{l}5 \\
\%\end{array}$ & 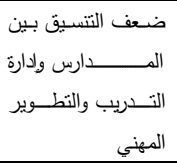 & 9 \\
\hline 6 & .72678 & $\begin{array}{l}2.3427 \\
\text { كبيرة }\end{array}$ & $\begin{array}{l}\text { ru } \\
\% 10, .\end{array}$ & $\begin{array}{l}\text { v } \\
\% \text { \% , v }\end{array}$ & $\begin{array}{l}1.0 \\
\% \leq 9, r\end{array}$ & $\begin{array}{l}5 \\
\%\end{array}$ & 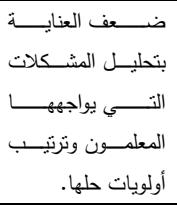 & 1. \\
\hline 11 & .67700 & 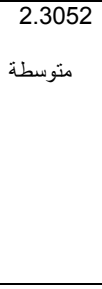 & $\begin{array}{l}r y \\
\% \backslash r, r\end{array}$ & $\begin{array}{l}97 \\
\% \leq 0,1\end{array}$ & $\begin{array}{l}91 \\
\% \leqslant r, V\end{array}$ & $\begin{array}{l}5 \\
\%\end{array}$ & 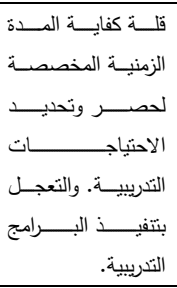 & 11 \\
\hline 10 & .74463 & 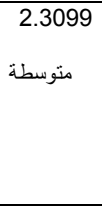 & $\begin{array}{r}r 4 \\
\% 17,9\end{array}$ & $\begin{array}{l}\text { vo } \\
\% \text { ro,r }\end{array}$ & $\begin{array}{l}1 . r \\
\% \leq r, q\end{array}$ & $\begin{array}{l}5 \\
\%\end{array}$ & 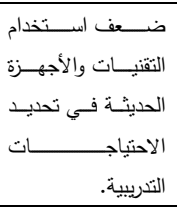 & IT \\
\hline 9 & .69210 & 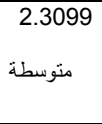 & $\begin{array}{l}\text { rA } \\
\% \mid r, 1\end{array}$ & $\begin{array}{l}91 \\
\leq r, V\end{array}$ & $\begin{array}{l}9 \leq \\
\% \leq \leq, 1\end{array}$ & $\begin{array}{l}5 \\
\%\end{array}$ & 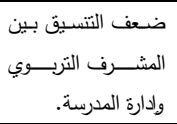 & $1 T$ \\
\hline 2 & .73677 & $\begin{array}{l}2.3991 \\
\text { كبيرة }\end{array}$ & $\begin{array}{l}\text { ru } \\
\% 10, .\end{array}$ & $\begin{array}{l}r \leqslant \\
\% r \cdot, \cdot\end{array}$ & $\begin{array}{l}11 V \\
\% \circ \varepsilon, 9\end{array}$ & $\begin{array}{l}5 \\
\%\end{array}$ & 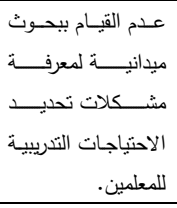 & $1 \leqslant$ \\
\hline & & " • ^ & لمعياري I & والان & ة ( متوب & 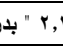 & ط الحسابي العام للمحو & \\
\hline
\end{tabular}

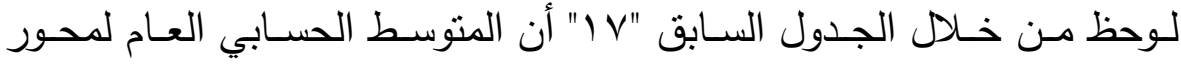

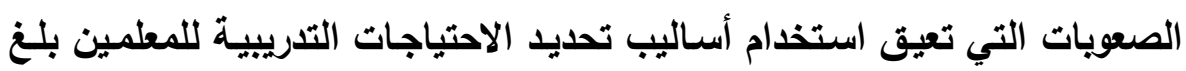

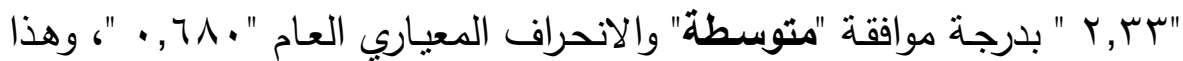
يدل على أنه من الصعوبة بمكان أن يتفق جميع أفراد العينة من معلمي التعليم

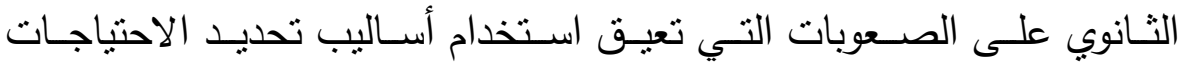


التدريبيـة، لأنه قد يواجـه بعض المعلمين صسعوبة تختلف عن صعوبة معلم آخر، وهذا شيء طبيعي؛ الأمر الذي أدى إلى عدم الاتفاق بدرجة كبيرة بين

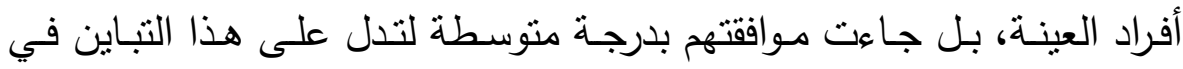

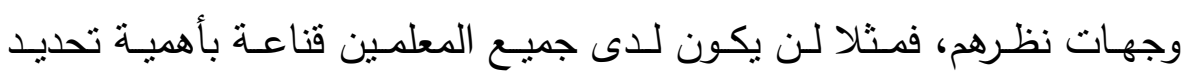

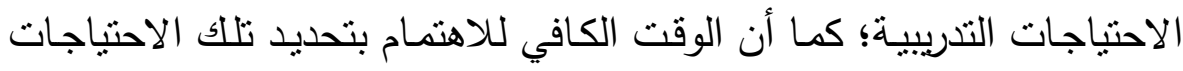

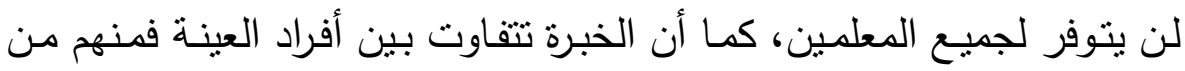

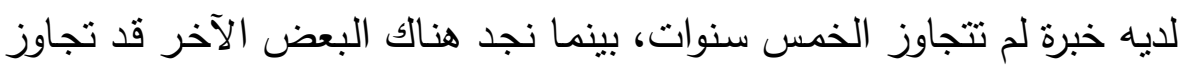
خبرته العشرين عامـا، كما تتفاوت الإدارات المدرسية من مدير لآخر ، فمنهم

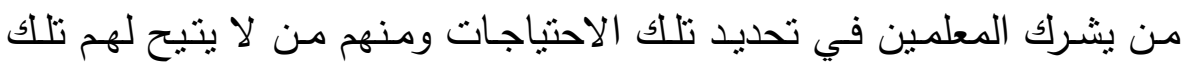
الفرصة؛ بل يفرض عليهم برامج معينة، وبذلك جاءت الموافقة على الصعوبات التي تعيق استخدام أساليب تحديد الاحتياجات التدريبية بدرجة متوسطة. وعندما طـرح سـؤال على عينـة الدراسـة حـول الصـعوبات التي تعيـق استخدام أسـاليب تحديد الاحتياجات التدريبية للمعلمين، جاءت إجاباتهم متتوعة ومتعددة

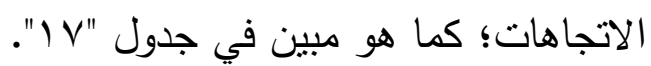
جاءت عبارة "ضعف التنسيق بين المدارس وإدارة التدريب والتطوير المهني "

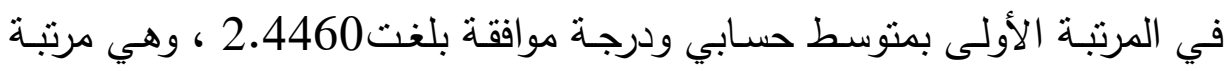
متقدمـة جداً، وتـدل على الإدراك الواضـح مـن المعلمين لهذه الصـعوبة؛ نظـراً

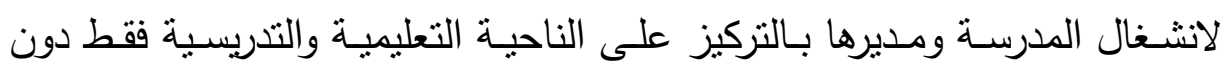
الاهتمام بالارتقاء بالتتمية المهنية للمعلمين، فجل اهتمام مدراء المدارس هو ملء

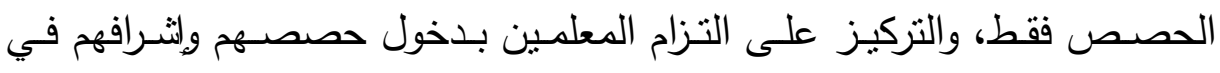

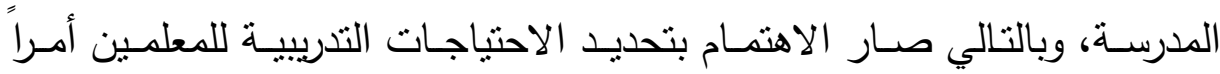

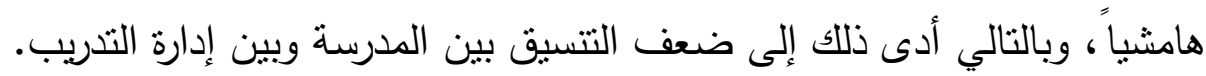

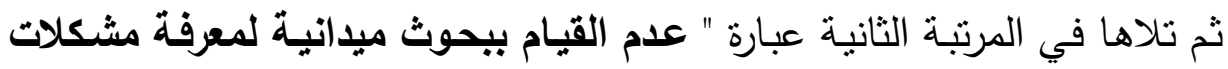

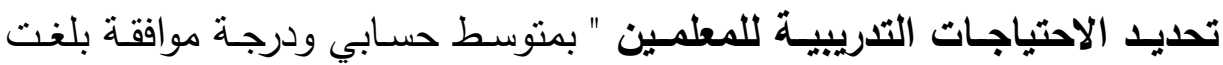


2.3991 ، وهذا يرتبط بالعبارة السابقة، فإذا لم يكن هناك اهتمام بذكر بالتتسيق

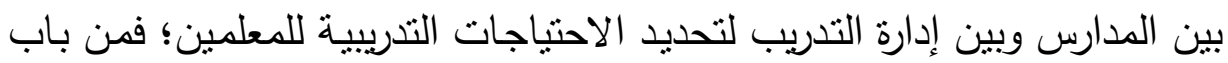
أولى لا يتم القبام ببحوث ميدانيـة لمعرفة مشكلات تحديد الاحتباجـات التدربييـة

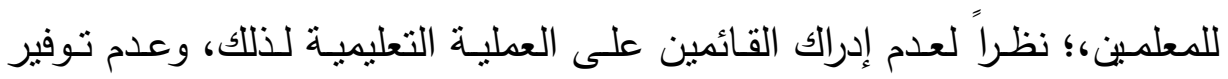

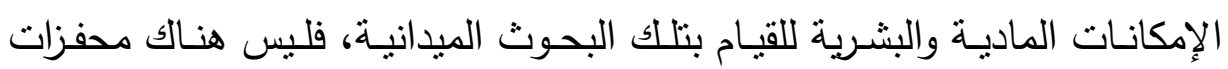
للقيام بذلك؛ سواء من المعلمين أنفسهم ، أو من غيرهم.

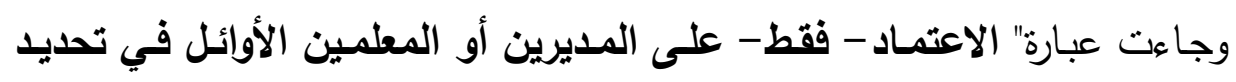

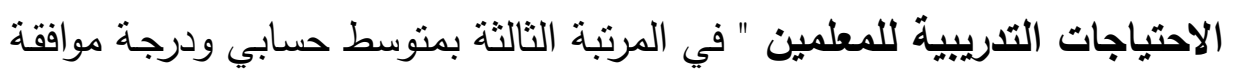

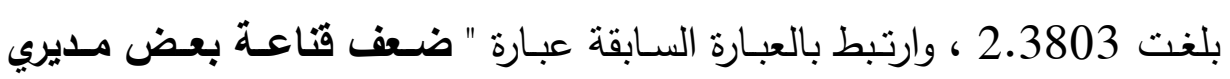

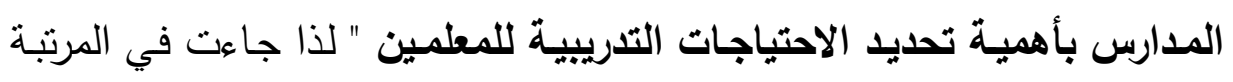

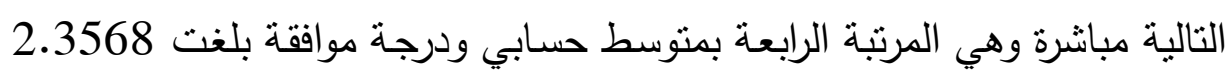

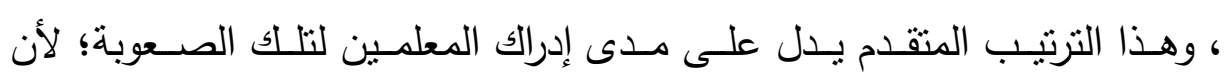

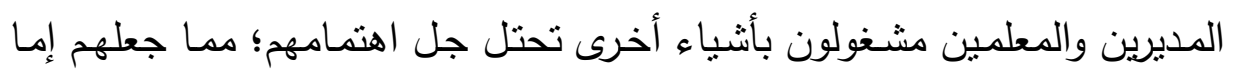

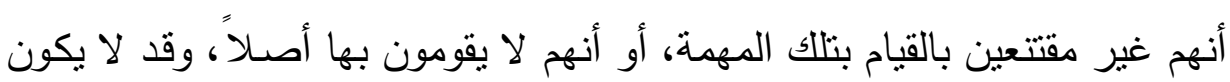

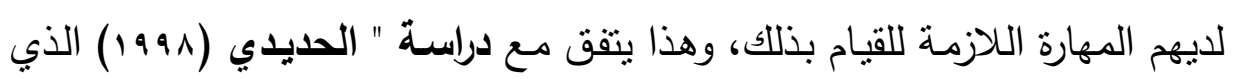

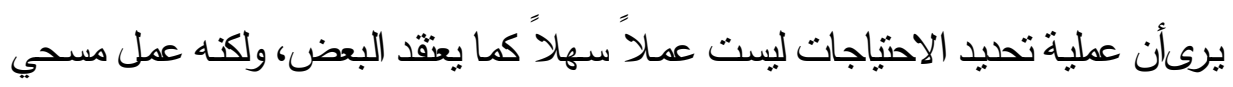

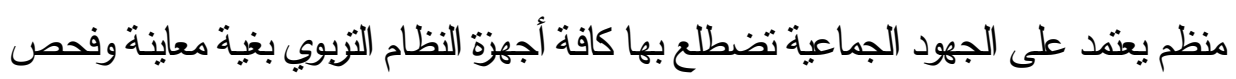
الفجوة المراد تحليدها، وتكون هذه الجهود في صورة برامج منظمة نسعى لتحليد الاحتياجات

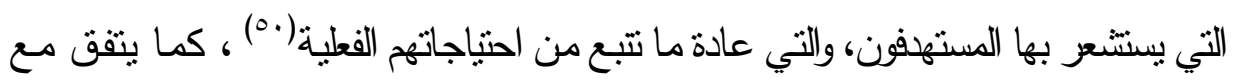

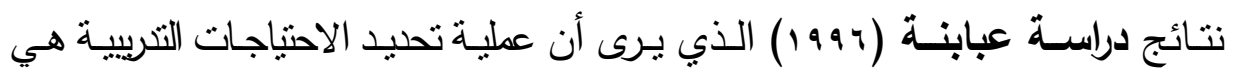

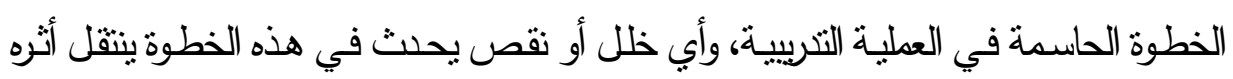
بالتأكيد إلى باقي خطوات التحربب، وفي نلك هدر كيير في الجهود والنفقات، بالإضافة لها

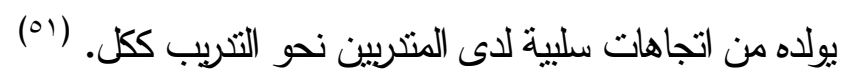


ثم توالى ترتيب العبارات حتى جاء في المرتبة الثانيـة عشرة عبارة " قلـة اهتمـام

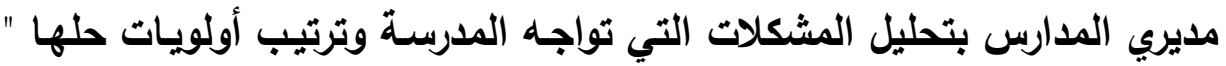

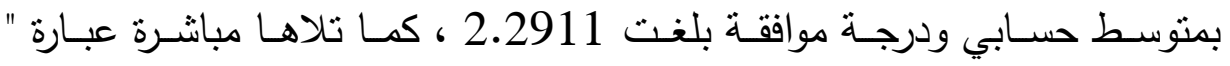
الافتقـار إلـى المعلومـات المتصــلة بالمؤثــــات الموضـوعية لأداء المعلمـين بالمدارس " في المرتبة الثالثة عشرة وقبل الأخيرة بمتوسط حسابي ودرجة موافقة

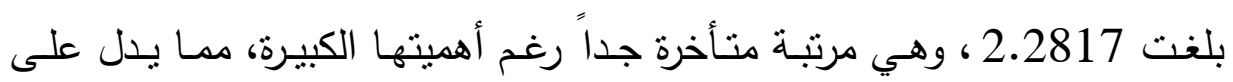

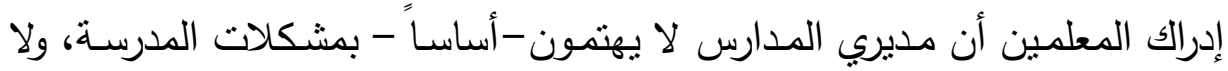

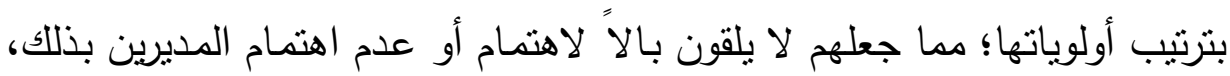
ولهذا جاء ترتيب هاتين العبارتين متأخرا؛ لأن المعلمين يدركون تمامـاً أن كثيرا

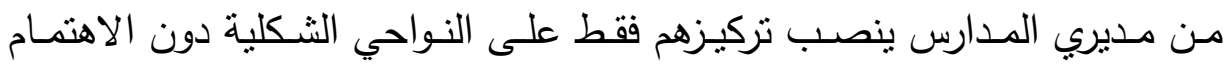

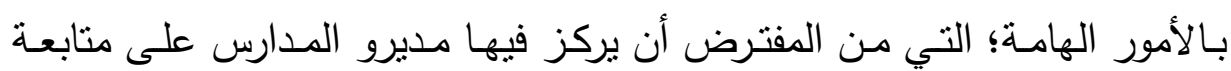

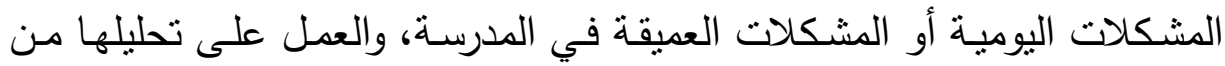

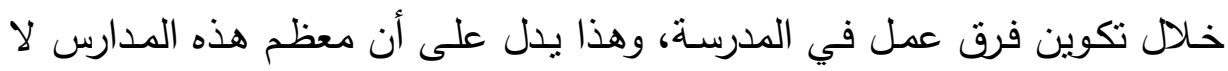
تطبق معايير الجودة الثاملة؛ التي تركز على العمل الجماعي في إدارة المدرسة

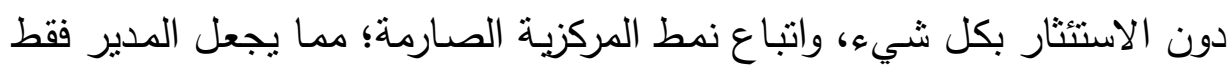
هو الثخص المنوط به كل شيء في المدرسة ، ومن هنا لا يستطيع المدير القيام

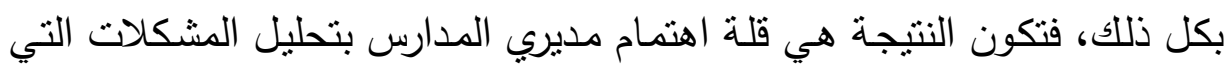

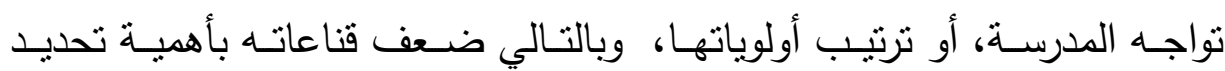

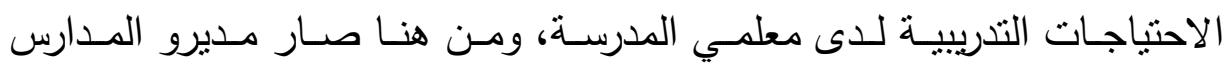

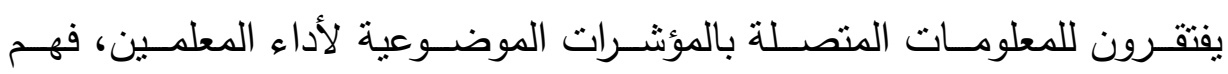

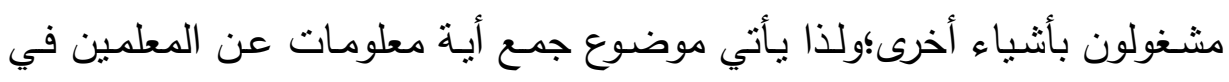

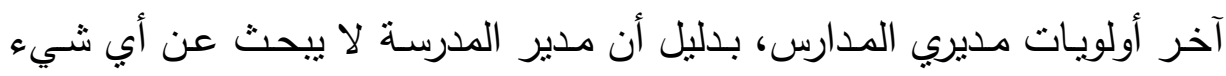

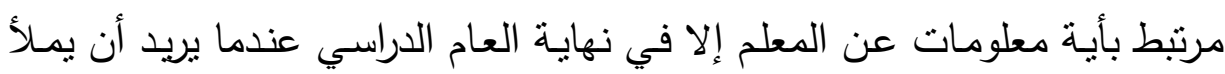

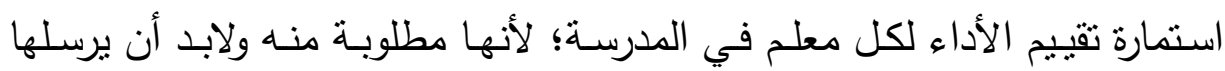


لإدارة الإشراف، هنا فقط يبدأ المدير البحث عن أية معلومات عن المعلم للانتهاء

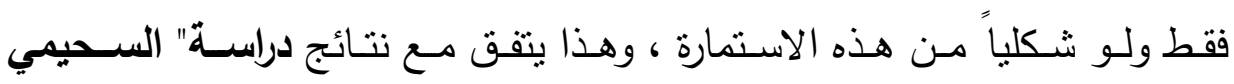

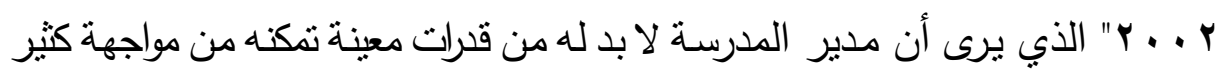

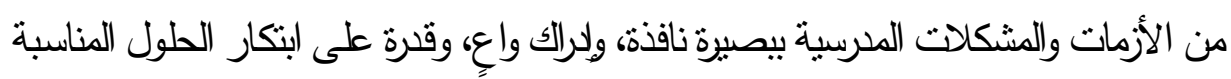
ونتفيذها في الوقت المناسب. (or)

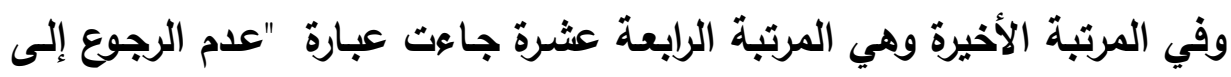

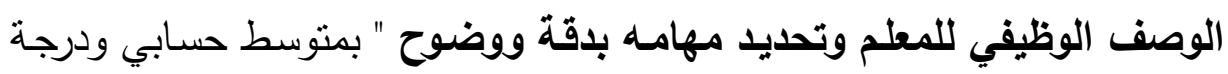

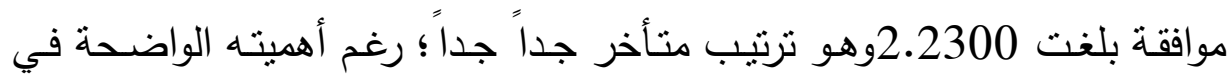

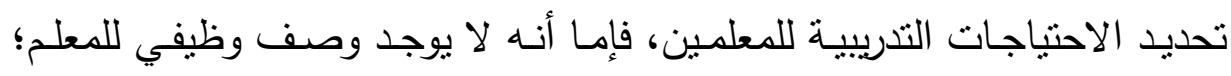

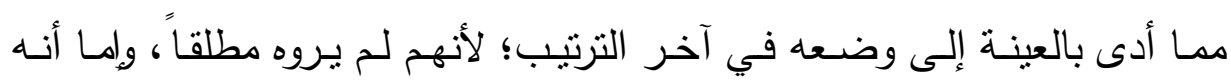

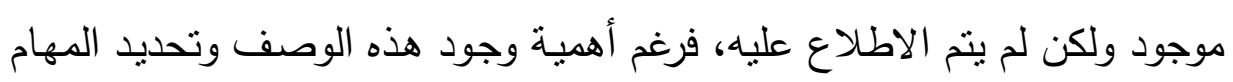

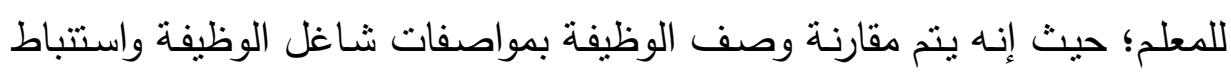
أهم المعارف والمهارات والكفايات والقدرات والصفات التي تتقصه، كما قد تجري مقارنة مواصفات الوظيفة الحقيقية بمواصفات الوظيفة الواقعية الحالية؛ وهنا يقوم

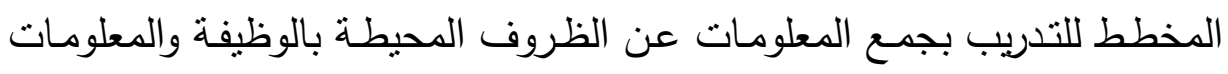
والمهارات والقدرات الضـرورية لأدائها؛ بهدف تحديد مـا يجب أن أن يعرفه المعلم

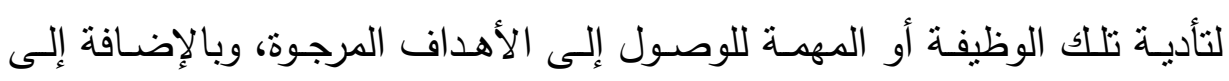

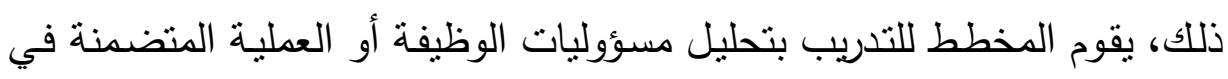

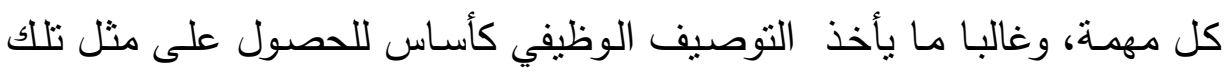

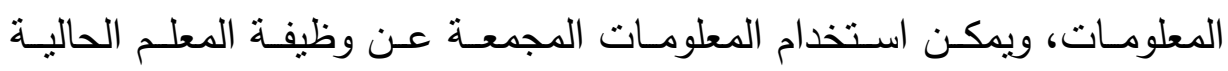
والمستقبلية لتحديد ما يجب أن يدرب عليه، وهذا يتطلب تحديد كل معايير الأداء

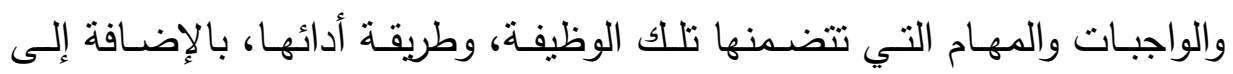

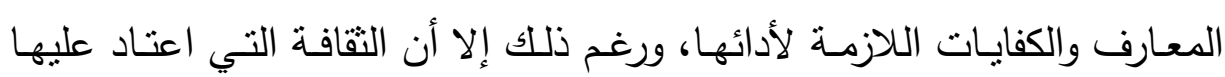
المعلمون هي عدم الرجوع، أو الاطلاع على مثل هذا التوصيف، فالمعلم بمجرد 
تخرجه واستلامه لوظيفة التدريس ينشخل في تتفيذ الحصص، والتحضير للدروس وغيرها من المهام التي اعتاد المعلم على أدائها. r - عرض نتائج المحور الثالث المتعلقة بفعالية أسـاليب تحديد الاحتياجـات التدريبية للمعلمين.

جدول (1 1 ):يوضح التكرارات والنسب المئوية والمتوسط الموزون والانحراف المعياري ودرجة الموافقة وترتيب العبارات للمحور الثالث "أسلوب المقابلات الثخصية مع المعلمين"

\begin{tabular}{|c|c|c|c|c|c|c|c|c|}
\hline \multirow[t]{2}{*}{ الترتيب } & \multirow{2}{*}{ الانحراف } & \multirow{2}{*}{ المسابي } & \multicolumn{3}{|c|}{ درجة الموافقة } & \multirow{2}{*}{ منوية } & \multirow[t]{2}{*}{ العبارات } & \multirow[t]{2}{*}{ م } \\
\hline & & & ضعيفة & متوسطة & كبيرة & & & \\
\hline 1 & .57972 & $\begin{array}{c}2.4977 \\
\text { كبيرة }\end{array}$ & $\begin{array}{c}9 \\
\% \varepsilon, r\end{array}$ & $\begin{array}{c}\wedge q \\
\% \leq 1, \wedge\end{array}$ & $\begin{array}{l}110 \\
\% 0 \leq,\end{array}$ & $\begin{array}{l}5 \\
\%\end{array}$ & تجاه البرامج عن التنريبية. & 1 \\
\hline 3 & .65512 & $\begin{array}{c}2.4648 \\
\text { كبيرة }\end{array}$ & $\begin{array}{c}19 \\
\% \wedge, 9\end{array}$ & $\begin{array}{c}\mathrm{V} \\
\% r o, v\end{array}$ & $\begin{array}{c}111 \\
\% 00, \varepsilon\end{array}$ & $\begin{array}{l}5 \\
\%\end{array}$ & تحديد أوجـه القصـور في أداء & r \\
\hline 5 & .61746 & $\begin{array}{c}2.4554 \\
\text { كبيرة }\end{array}$ & $\begin{array}{l}r T \\
\% 1 \cdot, r\end{array}$ & $\begin{array}{c}v r \\
\% r \leqslant, r\end{array}$ & $\begin{array}{c}111 \\
\% 00, \varepsilon\end{array}$ & $\begin{array}{l}5 \\
\%\end{array}$ & 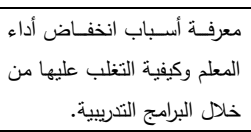 & r \\
\hline 4 & .67549 & $\begin{array}{l}2.4507 \\
\text { كبيرة }\end{array}$ & $\begin{array}{c}1 \leqslant \\
\% 4,7\end{array}$ & $\begin{array}{c}M \\
\% \leq 1, r\end{array}$ & $\begin{array}{l}111 \\
\% \circ r, 1\end{array}$ & \% & 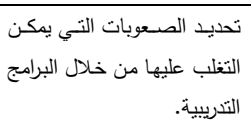 & $\varepsilon$ \\
\hline 2 & .64132 & $\begin{array}{l}2.4836 \\
\text { كبيرة }\end{array}$ & $\begin{array}{l}\text { IV } \\
\% \wedge, .\end{array}$ & $\begin{array}{c}\text { Vu } \\
\% \text { ro, }\end{array}$ & $\begin{array}{c}\text { Tr. } \\
\% \circ 4, r\end{array}$ & s & 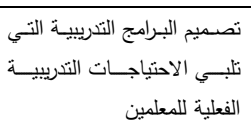 & 。 \\
\hline
\end{tabular}

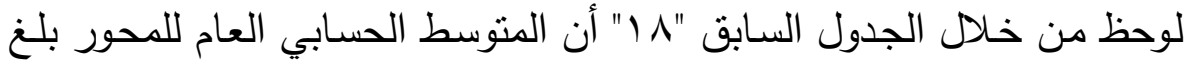

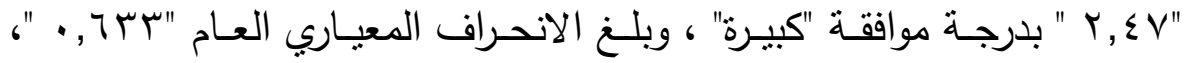

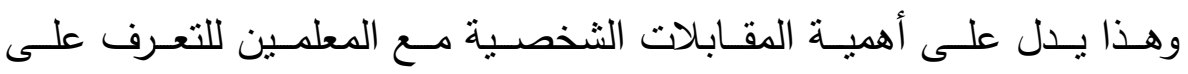
احتياجـاتهم التدربيـة، كمـا يـدل على إدراك المعلمين لضـرورة الحديث معهم؛ للتعرف على متطلباتهم من خلال الحديث المباشر؛ لأن الكلام المباشر معهم يظهر ردود أفعالهم، كما أنهم يشـعرون حينئذ بدورهم الفاعل، ويصبح لديهم رضـا نفسـي؛ نظـرا لمراعـاة آرائهم والاسـتماع ع إليهـا بشـكل مباشـر ، وبالتـالي DOI: $10.12816 / 0008988$ 
يـدفعهم ذلـك إلـى الاقتــاع بأهميـة وضـرورة الإقبـال على البـرامج التدربيــة وحضورها والاهتمام بها؛ لأنها تعبر عن وجهة نظرهم وعن احتياجاتهم الفعلية التي طالبوا بها ونقلوا رغبتهم في التدريب عليها. وبسؤال عينـة الدراسـة عـن فعاليـة "أسـلوب المقـابـلات الثخصـية مـع

المعلمين" جاءت استجاباتهم على النحو التالي كما هو مبين في جدول (1 ( ): فقد حظيت عبارة " الكشف عن اتجاهات المعلمين تجاه البرامج التدريبية " على الترتيب الأول، حيث بلـغ المتوسط الحسـابي ودرجة الموافقة 2.4977 ، كما جاءت عبارة " تصميم البرامج التدريبية التي تلبي الاحتياجات التدريبية الفعليـة للمعلمسين" في الترتيـب الثاني؛ حيـث بلـن المتوسـط الحسـابي ودرجـة الموافقة 2.4836 ، وهاتان العبارتان مرتبطتان ببعضهها؛ لأنه من المهم أن يـأتي الكثــ عـن اتجاهـات المعلمـين تجـاه البـرامج التدربيــة أولاً ، ثم يعقبهـا تصميم البرامج التدربيية التي تلبي هذه الاحتياجات التدربيية، بحيث تأني تلك البرامج المصممة متوافقة مـع متطلبات المعلمين، ولا تكون في واد آخر؛ فـلا يقبـل عليهـا المعلمـون، وتصـبح غيـر ذات قيمـة لهـ؛ فيكـون الأمـر مضـيعة للوقت.

كما جاءت عبارة " تحديد أوجـه القصدور في أداء المعلم " في الترنيب الثالث؛ حيث بلغ المتوسط الحسابي ودرجة الموافقة 2.4648 ، وجاءت عبارة " تحديد الصعويات التي يمكن التغلب عليها من خلال البرامج التدريبية " في الترتيب الرابـع؛ حيـث بلـنغ المتوسـط الحسـابي ودرجـة الموافقة 2.4507 ، بينمـا جـاءت عبارة " معرفة أسـباب انخفاض أداء المعلم وكيفيـة التقلب عليهـا مـن خـلال البـرامج التدريبيـة " في الترتيب الخـامس والأخير؛ حيـث بــن المتوسط الحسـي ودرجة الموافقة 2.4554 ، ومن الملاحظ أن العبارات الثناثث جاءت في ترتيب

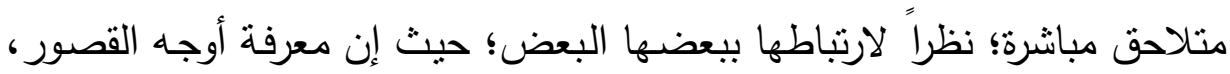
وأسباب انخفاض أداء المعلم، و معرفة الصعوبات التي يواجهها المعلم كلها تدور 


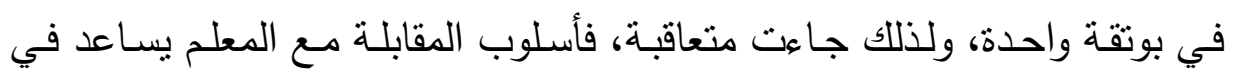

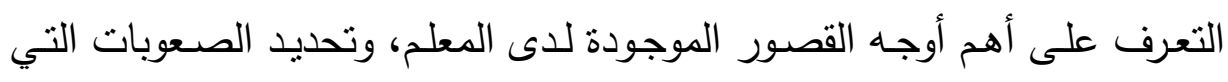

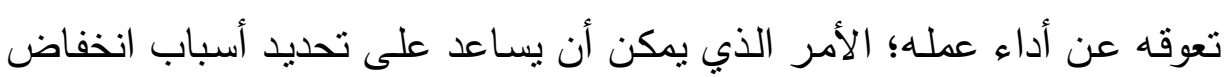

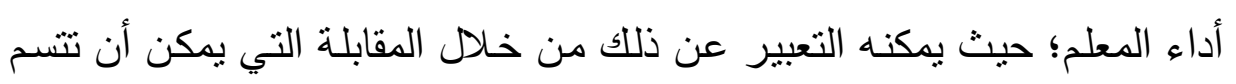

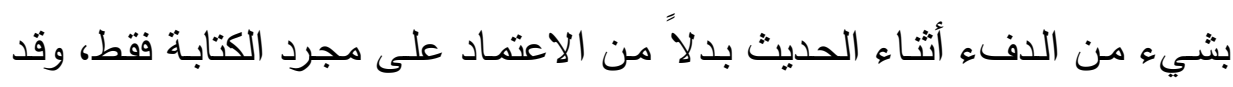

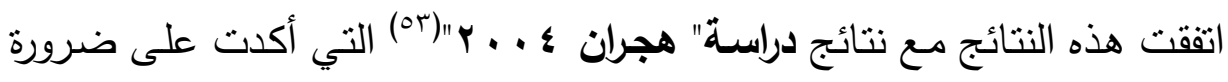
بنـاء برنامج تدريبي لتهيئة المعلمين المتميزين؛ للعمل الإثـرافي، ودعم الأفكار

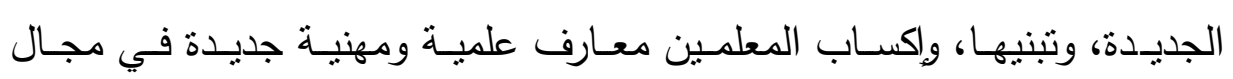
تخصصاتهم، والتعرف على التقنيات الحديثة في التدريس، والإفادة منها.

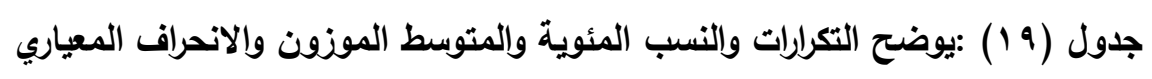

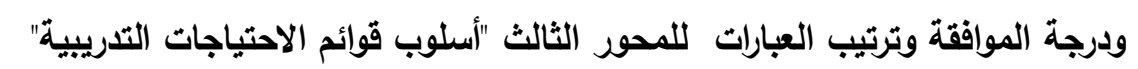

\begin{tabular}{|c|c|c|c|c|c|c|c|c|}
\hline \multirow[t]{2}{*}{ الترتيب } & \multirow{2}{*}{ المعياري } & \multirow{2}{*}{ المتوسط الحسابي } & \multicolumn{3}{|c|}{ درجة المواققة } & \multirow{2}{*}{ ن } & \multirow[t]{2}{*}{ العبارات } & \multirow[t]{2}{*}{ م } \\
\hline & & & ضعيفة & متوسطة & كبيرة & & & \\
\hline 1 & .54548 & $\begin{array}{c}2.6009 \\
\text { كبيرة }\end{array}$ & $\begin{array}{c}7 \\
\% \curlyvee, \wedge\end{array}$ & $\begin{array}{c}V T \\
\% r \varepsilon, r\end{array}$ & $\begin{array}{c}1 r \varepsilon \\
\% \pi r, q\end{array}$ & $\begin{array}{l}5 \\
\%\end{array}$ & ينبغي أن تتضمنها برامج التُريب. & 1 \\
\hline 2 & .60232 & $\begin{array}{c}2.5399 \\
\text { كبيرة }\end{array}$ & $\begin{array}{l}\text { 'r } \\
\% 0,7\end{array}$ & $\begin{array}{c}v \leq \\
\% r \leq, v\end{array}$ & $\begin{array}{l}\text { IrV } \\
\% \circ 9,7\end{array}$ & $\begin{array}{l}5 \\
\%\end{array}$ & كشف المهارات التي ينبغي تتميتها & r \\
\hline 4 & .65512 & $\begin{array}{c}2.4648 \\
\text { كبيرة }\end{array}$ & $\begin{array}{c}19 \\
\% \wedge, 9\end{array}$ & $\begin{array}{c}\mathrm{V} \\
\% r o, v\end{array}$ & $\begin{array}{l}111 \\
\% 00,8\end{array}$ & $\begin{array}{l}3 \\
\%\end{array}$ & تحديد الاتجاهات التي ينبغي & $r$ \\
\hline 5 & .62537 & $\begin{array}{c}2.4601 \\
\text { كبيرة }\end{array}$ & $\begin{array}{c}10 \\
\% \mathrm{v},\end{array}$ & $\begin{array}{l}10 \\
\%+9,9\end{array}$ & $\begin{array}{l}11 r \\
\% \circ r, 0\end{array}$ & $\begin{array}{l}5 \\
\%\end{array}$ & تحديد نوعية البرامج النتريبية التي & $\varepsilon$ \\
\hline 3 & .61896 & $\begin{array}{l}2.4883 \\
\text { كبيرة }\end{array}$ & $\begin{array}{l}1 \leqslant \\
\% \uparrow, 4\end{array}$ & $\begin{array}{l}\wedge 1 \\
\% r \wedge,\end{array}$ & $\begin{array}{l}111 \\
\% 00, \varepsilon\end{array}$ & $\begin{array}{l}5 \\
\%\end{array}$ & 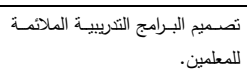 & 0 \\
\hline
\end{tabular}

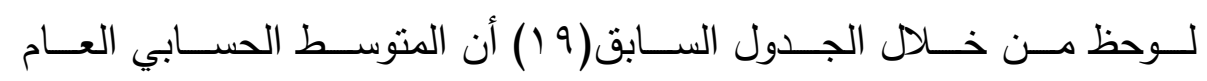

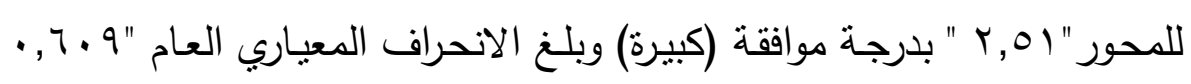

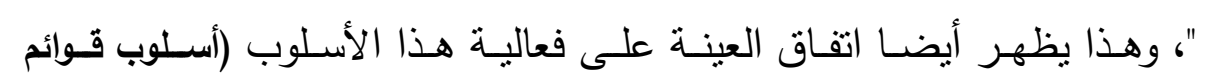

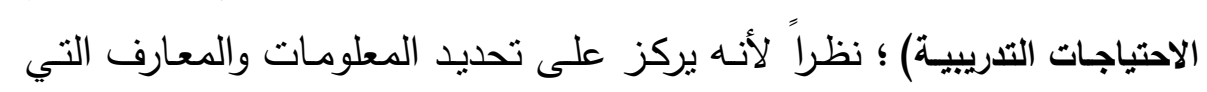

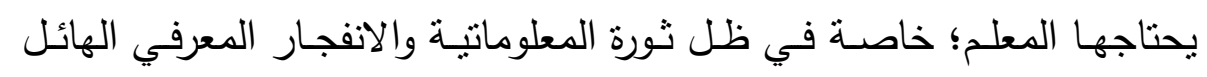

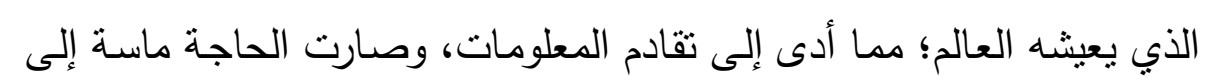

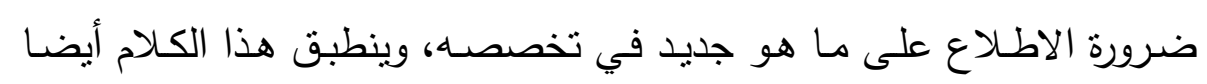


على المهارات التي يشعر المعلم أنه في احتباج لها، بالإضـافة إلى التركيز

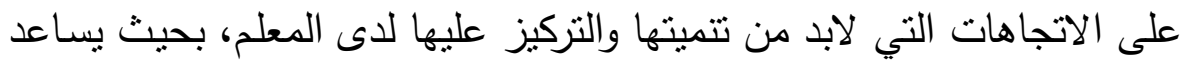

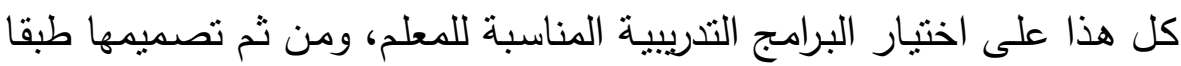
لاحتياجاته وتوجهاته. وبسؤال عينة الدراسة عن فعالية " أسلوب قوائم الاحتياجات التدريبية " جاءت استجاباتهم على النحو التالي كما هو مبين في جدول (9 (1):

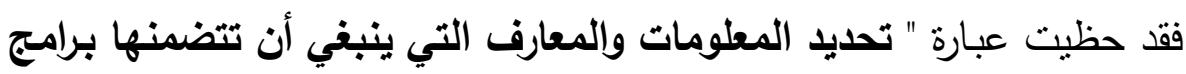
التـدريب" على التزتيب الأول،؛ حيث بلـن المتوسط الحسـابي ودرجـة الموافقة

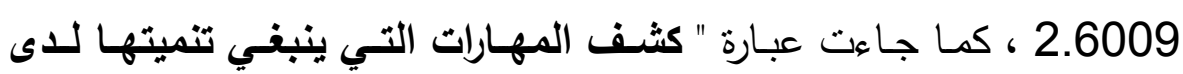

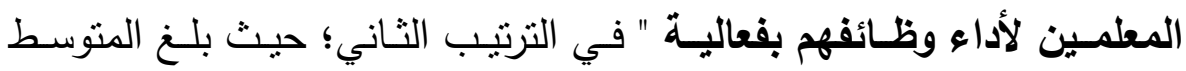
الحسابي ودرجة الموافقة 2.5399 ، وقد جاء ترتيبهم منطقيا؛ حيث إنه لابد من معرفة الثق النظري أولا والمتمنل في تحديد المعلومات والمعارف التي لابد

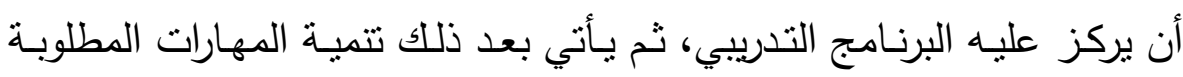

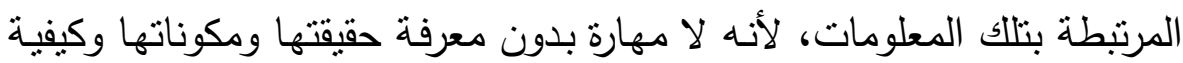

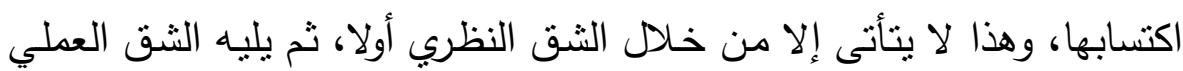
أو التطبيقي المتمنل في المهارة التي يتم اكتسابها.

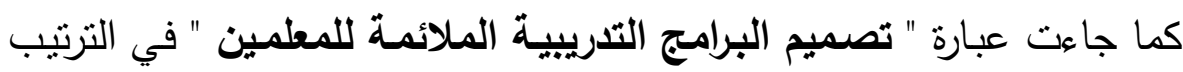

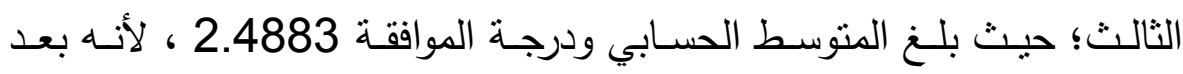

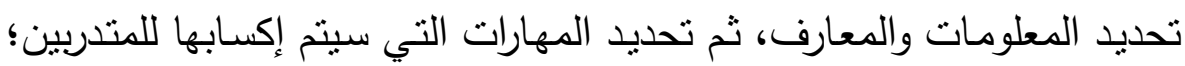

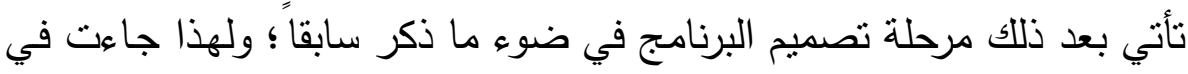

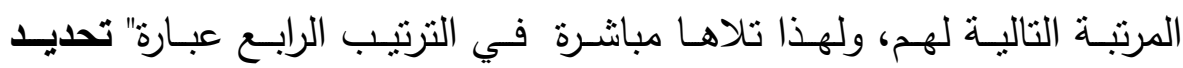

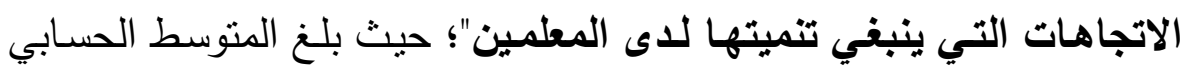
ودرجة الموافقة 2.4648 ، وهكذا يسير ترتيب العبارات بشكل منضبط وملفت للنظر ؛ لأنـه بعد اكتساب المعارف والمعلومات والمهارات يتم إحداث التغيير 
المطلوب في السلوك، ومن هنا جاءت عبارة " تحديد الاتجاهات التي ينبغي

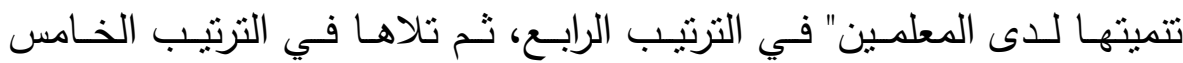

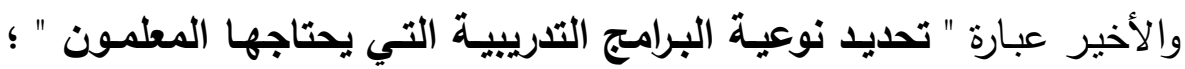

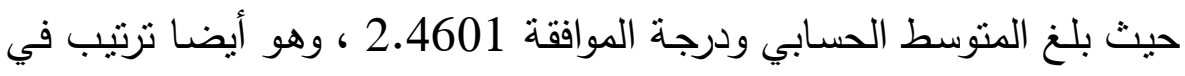
محله؛ لأنه في النهاية بعد تحديد المعلومات والمهارات والاتجاهات يأتي تحديد النوعيـة المناسبة لكل معلم من البرامج التدريبيـة، وجاءت نتائج هذا المحور

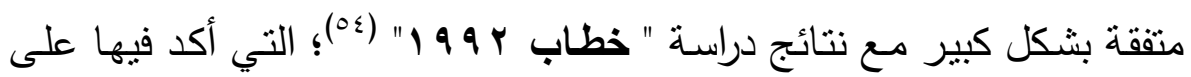
ضـرورة التركيز على كفايـات تتعلق بمواكبـة المستجدات في المـادة العلميـة

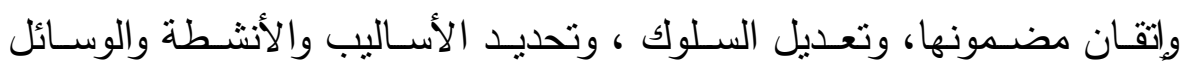
المناسبة، واستثارة دافعية التلاميذ. جدول (· r) يوضح التكرارات والنسب المئوية والمتوسط الموزون والانحراف المعياري ودرجة الموافقة وترتيب العبارات للمحور الثالث "أسلوب الزيارات الصفية"

\begin{tabular}{|c|c|c|c|c|c|c|c|c|}
\hline \multirow[t]{2}{*}{ الترتيب } & \multirow{2}{*}{ الانحراف } & \multirow{2}{*}{ الحسابي ودرجة المتوسط } & \multicolumn{3}{|c|}{ درجة الموافقة } & \multirow{2}{*}{ نسئ } & \multirow[t]{2}{*}{ العبارات } & \multirow[t]{2}{*}{ p } \\
\hline & & & ضعيفة & متوسطة & كبيرة & & & \\
\hline 3 & .67549 & $\begin{array}{l}2.4507 \\
\text { كبيرة }\end{array}$ & $\begin{array}{l}r Y \\
\% 1 \cdot, r\end{array}$ & $\begin{array}{l}V r \\
\% r \varepsilon, r\end{array}$ & $\begin{array}{l}111 \\
\% 00, \varepsilon\end{array}$ & $\begin{array}{l}5 \\
\%\end{array}$ & 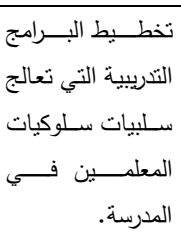 & 1 \\
\hline 1 & .61907 & $\begin{array}{l}2.4977 \\
\text { كبيرة }\end{array}$ & $\begin{array}{l}1 \leq \\
\% \curlyvee, 7\end{array}$ & $\begin{array}{l}v q \\
\% r v, 1\end{array}$ & $\begin{array}{l}\text { Kr. } \\
\% \circ 7, r\end{array}$ & $\begin{array}{l}5 \\
\%\end{array}$ & 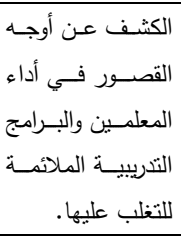 & $r$ \\
\hline 2 & .63409 & $\begin{array}{l}2.4930 \\
\text { كبيرة }\end{array}$ & $\begin{array}{l}17 \\
\% \vee, 7\end{array}$ & $\begin{array}{l}v 4 \\
\% r o, v\end{array}$ & $\begin{array}{l}|r| \\
\% \circ 7, \wedge\end{array}$ & $\begin{array}{l}5 \\
\%\end{array}$ & 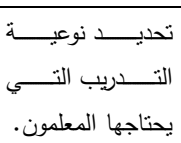 & $r$ \\
\hline 5 & .64500 & $\begin{array}{l}2.3803 \\
\text { كبيرة }\end{array}$ & $\begin{array}{l}19 \\
\% \wedge, 9\end{array}$ & $\begin{array}{l}9 \leq \\
\% \leq \varepsilon, 1\end{array}$ & $\begin{array}{l}1 \cdots \\
\% \leq 7,9\end{array}$ & $\begin{array}{l}5 \\
\%\end{array}$ & 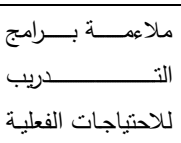 & $\varepsilon$ \\
\hline
\end{tabular}




\begin{tabular}{|c|c|c|c|c|c|c|c|c|}
\hline \multirow[t]{2}{*}{ الترتيب } & \multirow{2}{*}{ الالنحراف } & \multirow{2}{*}{ الحسابي ودرجة } & \multicolumn{3}{|c|}{ درجة الموافقة } & \multirow{2}{*}{ مئمبة } & \multirow[t]{2}{*}{ العبارات } & \multirow[t]{2}{*}{ p } \\
\hline & & & ضعيفة & متوسطة & كبيرة & & & \\
\hline & & & & & & & للمعلمين & \\
\hline 4 & 62936 & $\begin{array}{l}2.4225 \\
\text { كبيرة }\end{array}$ & $\begin{array}{l}17 \\
\% \vee, 7\end{array}$ & $\begin{array}{l}91 \\
\% \leqslant r, Y\end{array}$ & $\begin{array}{l}1.7 \\
\% \leq 4, \wedge\end{array}$ & \% & 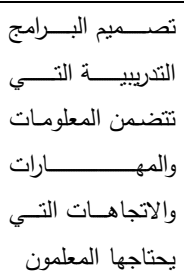 & 。 \\
\hline & & ي العام " . ؛ & حراف & كبيرة ) & لرجة موا & 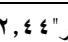 & ط الحسابي العام للد & \\
\hline
\end{tabular}

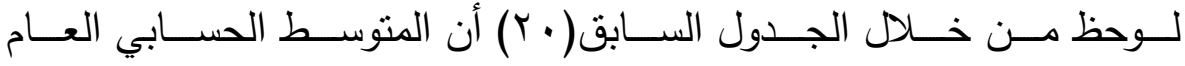

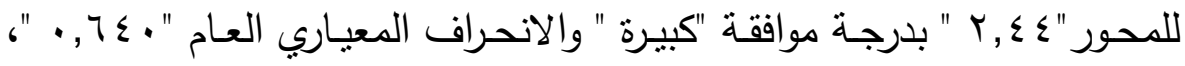

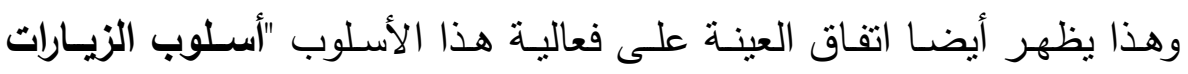

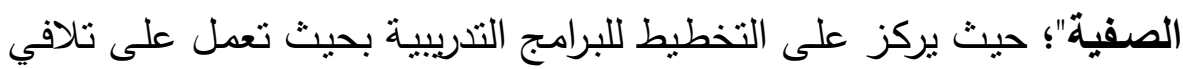
النواحي السلبية التي قد توجد للدى بعض المعلمين، من خـلال اختيار نوعية مناسبة من التدريب يرى المعلمون أنهم في احتياج لها، وبالتالي يتم التركيز عند تصميم البرامج التتريبية على تلك الاحتباجات التي يراها المعلمون

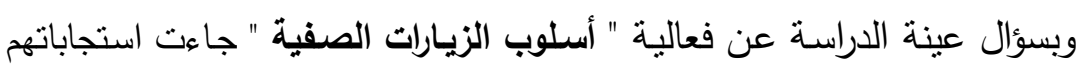

$$
\text { على النحو التالي كما هو مبين في جدول (· ب): }
$$

فقد حظيت عبارة " الكثف عن أوجه القصور في أداء المعلمين والبرامج التدريبية

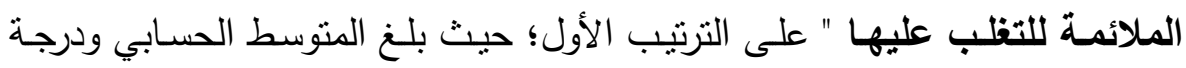

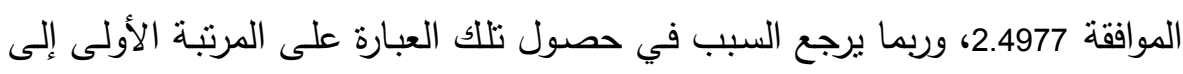

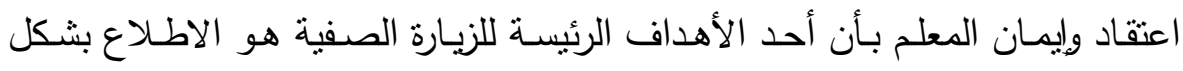

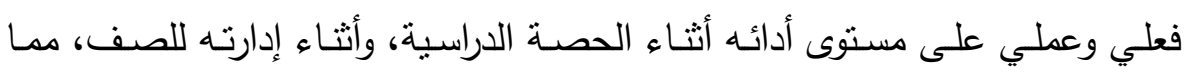

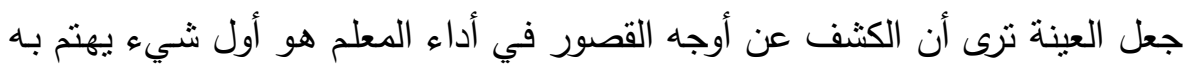

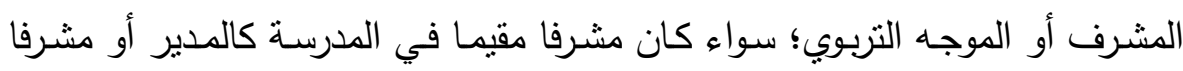

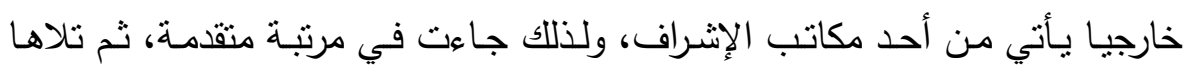

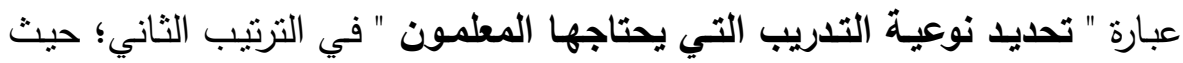
بلـخ المتوسط الحسابي ودرجة الموافقة 2.4930؛ وهو ترتيب منطقي أيضـا؛ لأنسه بناء lov 
على تحديد أوجـه القصور يتم بنـاء برامج تدربيية متتوعـة بحيث تتاسب المعلمين، وتسـاعد في عـلاج أوجـه القصـور التي يعـاني منهـا بعضـهم؛ ولهذا جـاءت عبـارة " تخطيط البرامج التدريبية التي تعالج سلبيات سلوكيات المعلمين في المدرسة " في الترتيب الثالث؛ حيث بلغ المتوسط الحسابي ودرجة المواققة 2.4507 ـ وهكذا نرى بوضوح ترنيباً مميزاً للعبارات بشكل كبير ، فبعد تحديد نوعية البرامج التربيية المطلوبـة يتم التخطيط لها؛ بحيث تحقق الأهداف التي وضعت من أجلها وهو عـلاج سلبيات سلوكيات المعلمين في المدرسـة، بحيث يتم مراعاة الفئة المستهدفة، واختبـار المكـان المجهز والمناسـب للتدريب، وتحديــ الوقت المناسـب، وغيرهـا مـن الأمسور التي لابـد مـن مراعاتها عند التخطيط للبرنـامج التدريبي، وبعد الانتهاء من التخطيط للبرنامج التدريبي يتم تصميم البرنامج، وتحديد أهدافه وتحديد محتواه ، وكيفيـة تقويمه، وغيرهـا مـن الأمور التي يتم مراعاتها في التصسيم؛ ولهذا تلاهـا مباشـرة في الترتيب الرابع عبـارة" تصـميم البـرامج التدريبيـة التـي تتضــن المعلومـات والمهـارات والاتجاهـات التي يحتاجها المعلمون " ؛ حيث بلـغ المتوسط الحسابي ودرجة الموافقة 2.4225، وهو ترتيب يتماشـى مـع الترتيب الذي يتم مراعاته عند إعداد البرامج التدريبية ، ثم تلاها في الترتيب الخامس والأخير عبارة " ملاعمـة برامج التدريب للاحتياجات الفعلية للمعلمين " ؛ حيث بلغ المتوسط الحسابي ودرجة الموافقة 2.3803 ، حيث يراعى أن تكون البرامج التدربيية ملائمة للاحتياجات الفعلية

للمعلمين. جدول ( I Y ) يوضـح التكرارات والنسب المئويـة والمتوسط الموزون والانحراف المعياري ودرجة الموافقة وترتيب العبارات للمحور الثالث "أسلوب الاستقصاءات التي يجريها مدير

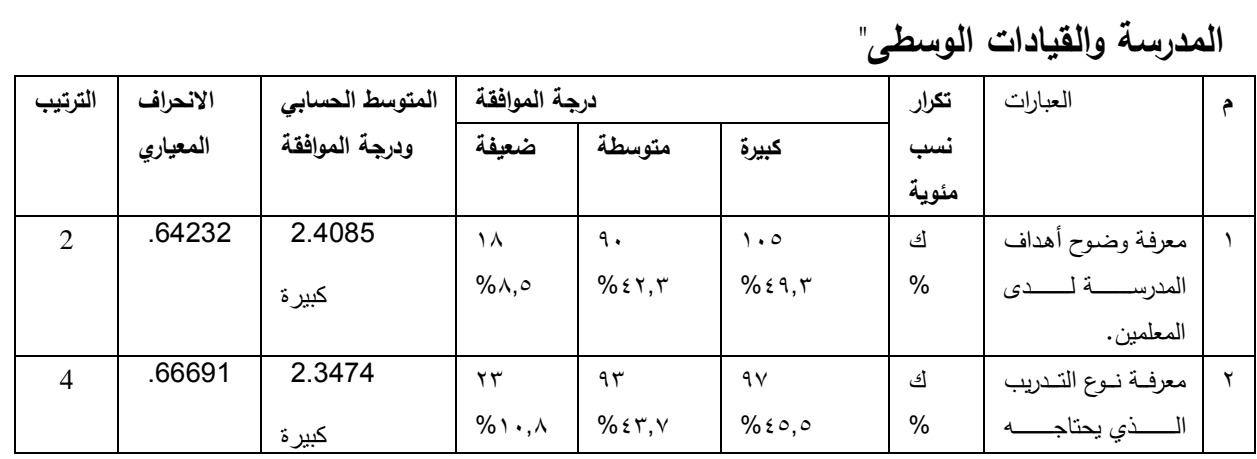




\begin{tabular}{|c|c|c|c|c|c|c|c|c|}
\hline \multirow[t]{2}{*}{ الترتيب } & \multirow{2}{*}{ الانحراف } & \multirow{2}{*}{ ولمرجة الموافقة الحسابي } & \multicolumn{3}{|c|}{ درجة الموافقة } & \multirow{2}{*}{ نكرية } & \multirow[t]{2}{*}{ العبارات } & \multirow[t]{2}{*}{ م } \\
\hline & & & ضعيفة & متوسطة & كبيرة & & & \\
\hline & & & & & & & المعلمون. & \\
\hline 1 & .61140 & $\begin{array}{l}2.4977 \\
\text { كبيرة }\end{array}$ & $\begin{array}{l}15 \\
\% \pi, 1\end{array}$ & $\begin{array}{l}\text { ᄉ) } \\
\% r \wedge,\end{array}$ & $\begin{array}{l}119 \\
\% 00,9\end{array}$ & $\begin{array}{l}5 \\
\%\end{array}$ & 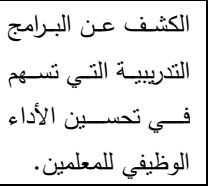 & r \\
\hline 3 & .70808 & $\begin{array}{l}2.3474 \\
\text { كبيرة }\end{array}$ & $\begin{array}{l}r q \\
\% \backslash r, T\end{array}$ & $\begin{array}{l}\wedge 1 \\
\% r \wedge, \text {. }\end{array}$ & $\begin{array}{l}1 \cdot r \\
\% \leq \wedge, \varepsilon\end{array}$ & $\begin{array}{l}5 \\
\%\end{array}$ & 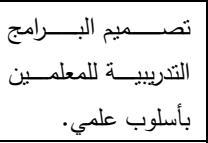 & $\varepsilon$ \\
\hline 5 & .72413 & $\begin{array}{l}2.3052 \\
\text { كبيرة }\end{array}$ & $\begin{array}{l}\text { \% } \\
\% 10,0\end{array}$ & $\begin{array}{l}\wedge r \\
\% r \wedge, 0\end{array}$ & $\begin{array}{l}91 \\
\% \leq 7, .\end{array}$ & $\begin{array}{l}5 \\
\%\end{array}$ & 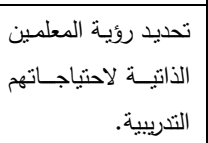 & 0 \\
\hline
\end{tabular}

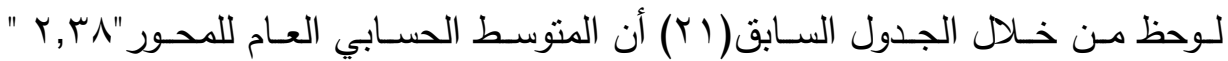
بدرجـة موافقة (كبيرة ) والانحراف المعيـاري العـام " • VT, · "، وهذا يظهر أيضـا اتفاق العينـة على فعالية هذا الأسلوب "أسـلوب الاستقصـاءات التي يجريهـا مدير المدرسـة والقيادات الوسطى"؛ نظراً لأهميته بالإسهام في معرفة وضوح أهداف المدرسة ، ودورها في معرفة نوع التدريب الذي يحتاجه المعلمون، بالإضافة للكثف عن البرامج التدريبية التي تسهـم في تحسين الأداء الوظيفي للمعلمين، وكذلك المسـاعدة في تصميم البرامج التدريبيـة للمعلمين بأسـلوب علمي، الأمـر الذي يؤدي إلى تحديد رؤيسة ذاتيـة للمعلمين حول احتياجاتهم التدريبية. وبسؤال عينـة الدراسـة عن فعاليـة أسـوب " الاستقصـاءات التي يجريهـا مـدير المدرسـة والقيادات الوسطى ونوان " جاءت استجاباتهم على النحو التالي كما هو مبين في جدول (Y) : فقد حظيت عبارة " الكثف عن البرامج التدريبية التي تسهم في تحسين هونين الأداء الوظيفي للمعلمين " على الترتيب الأول؛ حيث بلغ المتوسط الحسابي ودرجة

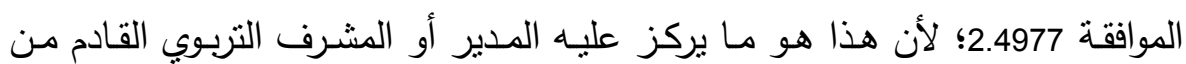
إحدى مكاتب الإتراف، حيث إنه من صميم عمله، ومن مهامه الرئيسة التركيز على هي هئ ذلك؛ ولبس شيئًا آخر ، حتى يضمن تحقيق تقدم ملحوظ في تحسين أدائهم الوظيفي، ثم تلاها عبارة " معرفة وضوح أهداف المدرسة للدى المعلمين " في الترتيب الثاني؛ 109 
حيث بلغ المنتوسط الحسابي ودرجة الموافقة 2.4085، وهذا شيء هام أن يتأكد مدير

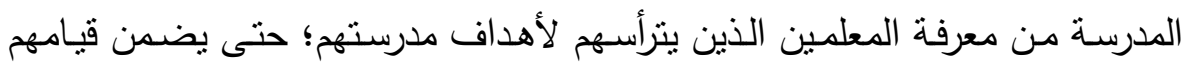

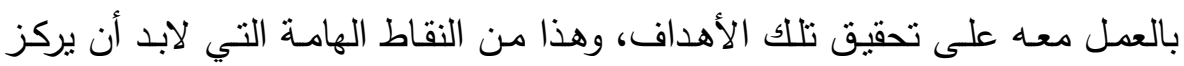

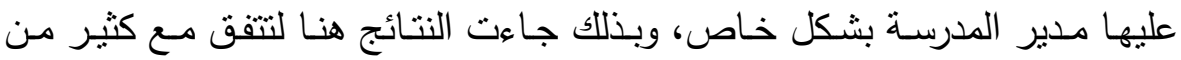

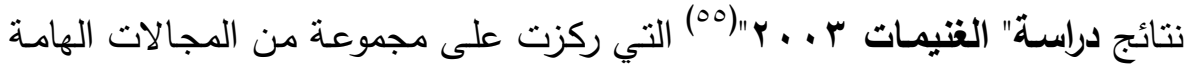
والتي لابد من مراعاتها عند بناء البرامج التي تسهه في الارتقاء بـالأداء الوظيفي للمعلمين وتحسينه.

ثم جاءت عبارة " تصميم البرامج التدريبية للمعلمين بأسلوب علمي " في وني التزتيب الثالث؛ حيث بلـغ المتوسط الحسابي ودرجـة الموافقة 2.3474 ، وقد جاءت بات

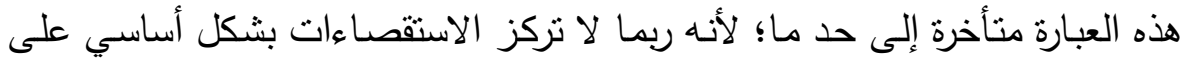

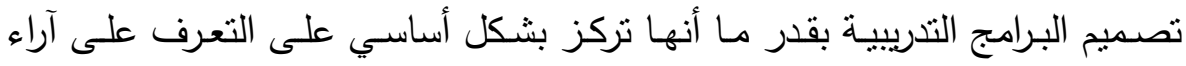
المعلمين تجاه البرامج التدريبية؛ سواء المنفذة أو التي بريدون تتفيذها مستقبلاً. تلاها مباثرة في التزتيب الرابع عبارة" معرفة نوع التدريب الذي يحتاجها

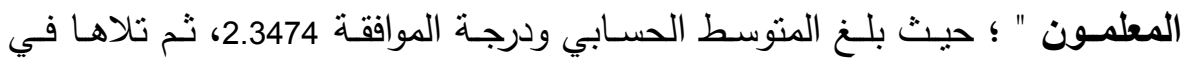
الترتيب الخامس والأخير عبارة " تحديد روئية المعلمين الذاتية لاحتياجاتهم التدريبية

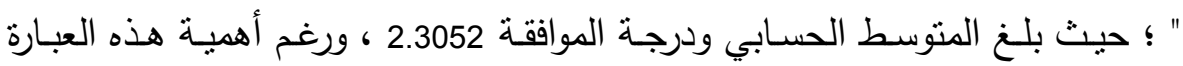

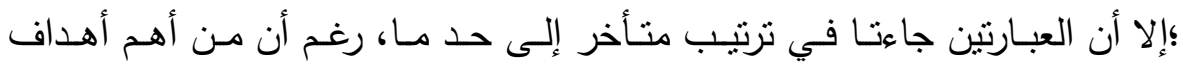

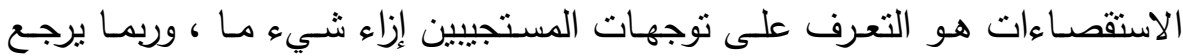

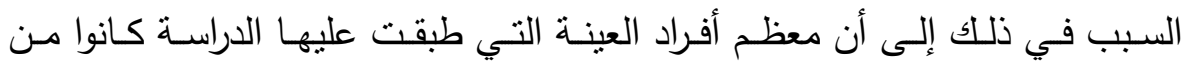
المعلمين الجدد؛ والذين لم تتجاوز فترة خبرتهم خمس سنوات؛ مما جعلهم لا يهتمون

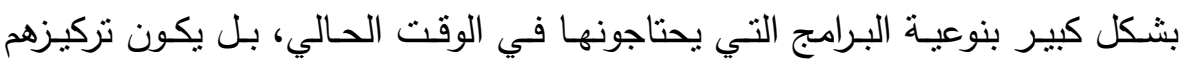

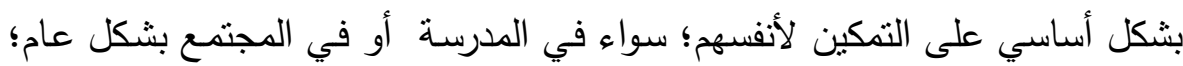

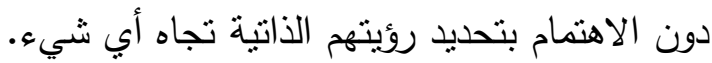

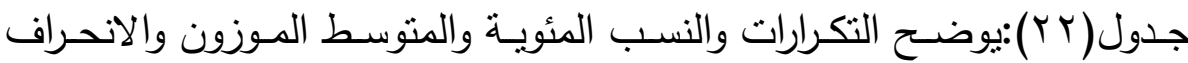

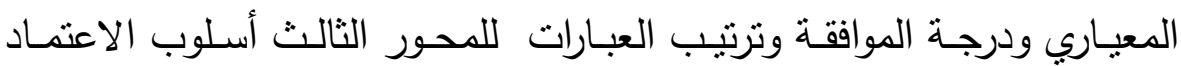


على الخبراء والمتخصصـين في جمـع المعلومـات عن الاحتياجـات التدربيـة للمعلمبن

\begin{tabular}{|c|c|c|c|c|c|c|c|c|}
\hline \multirow[t]{2}{*}{ الترتيب } & \multirow{2}{*}{ الانحراف } & \multirow{2}{*}{ 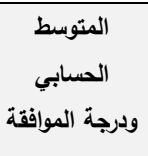 } & \multicolumn{3}{|c|}{ درجة الموافقة } & \multirow{2}{*}{ نكرار } & \multirow[t]{2}{*}{ العبارات } & \multirow[t]{2}{*}{ ? } \\
\hline & & & ضعيفة & متوسطة & كبيرة & & & \\
\hline 1 & $\begin{array}{l}.6488 \\
0\end{array}$ & $\begin{array}{l}2.4930 \\
\text { كبيرة }\end{array}$ & $\begin{array}{l}1 \wedge \\
\% \wedge, 0\end{array}$ & $\begin{array}{l}\text { VT } \\
\% r r, \wedge\end{array}$ & $\begin{array}{l}\text { \%OV, } \\
\text { \%r }\end{array}$ & $\begin{array}{l}5 \\
\%\end{array}$ & 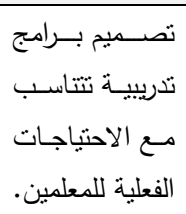 & 1 \\
\hline 2 & $\begin{array}{l}.6798 \\
0\end{array}$ & $\begin{array}{l}2.4225 \\
\text { كبيرة }\end{array}$ & $\begin{array}{l}r r \\
\% 1 \cdot, \lambda\end{array}$ & $\begin{array}{l}V V \\
\% r 4, Y\end{array}$ & $\begin{array}{l}11 r \\
\% \circ r, 1\end{array}$ & $\begin{array}{l}5 \\
\%\end{array}$ & 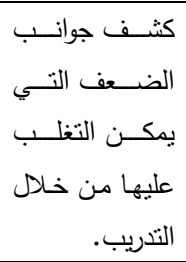 & $r$ \\
\hline 3 & $\begin{array}{l}.6633 \\
1\end{array}$ & $\begin{array}{l}2.4038 \\
\text { كبيرة }\end{array}$ & $\begin{array}{l}r) \\
\% 9,9\end{array}$ & $\begin{array}{l}\text { 10 } \\
\% r q, q\end{array}$ & $\begin{array}{l}1 \cdot v \\
\% \cdot \cdot r\end{array}$ & $\begin{array}{l}5 \\
\%\end{array}$ & 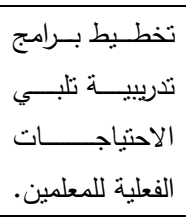 & $r$ \\
\hline 4 & $\begin{array}{l}.6554 \\
6\end{array}$ & $\begin{array}{l}2.3991 \\
\text { كبيرة }\end{array}$ & $\begin{array}{l}r \cdot \\
\% q, \varepsilon\end{array}$ & $\begin{array}{l}\text { M } \\
\% \leqslant 1, r\end{array}$ & $\begin{array}{l}1.0 \\
\% \leqslant 9, r\end{array}$ & $\begin{array}{l}\text { 5 } \\
\%\end{array}$ & 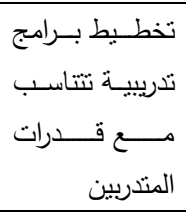 & $\varepsilon$ \\
\hline 5 & $\begin{array}{l}.6474 \\
7\end{array}$ & $\begin{array}{l}2.3944 \\
\text { كبيرة }\end{array}$ & $\begin{array}{l}19 \\
\% \wedge, 9\end{array}$ & $\begin{array}{l}91 \\
\% \leqslant r, \vee\end{array}$ & $\begin{array}{l}1 \cdot r \\
\% \leq \wedge, \varepsilon\end{array}$ & $\begin{array}{l}\text { 5 } \\
\%\end{array}$ & 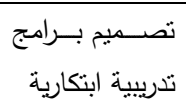 & 0 \\
\hline
\end{tabular}

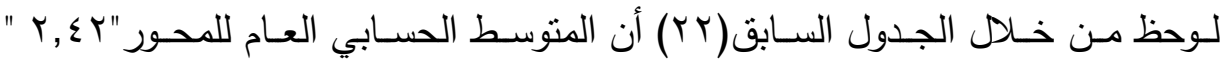
بدرجـة موافقة (كبيـرة )والانحـراف المعيـاري العـام" 709, ، "، وهـذا بظهر أيضـا اتفـاق

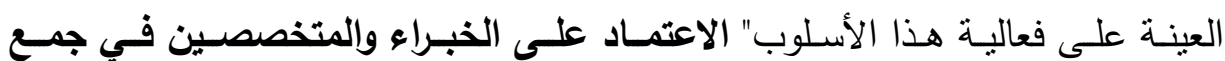
المعلومـات عن الاحتياجات التديبية للمعلمين"؛ نظراً لتركيزه على تصميم برامج تدريبية تتتاسب مع الاحنياجات الحقيقية للمعلمين،الأمر الذي يؤدي إلى كثف جوانب الضعف لدى بـى بردي بعضض المعلمـين؛ بحيـث يـتم التغلـب عليهـا، وبالتـالي التخطيط بشـكل فعـال للبـرامج التدريبيـة التي تلبي احتياجاتهم،وتتتاسب مـع قدراتهم وتخصصـاتهم، الأمـر الذي يؤدي 
في النهاية إلى ابتكار العديد من البرامج التدريبية التي يحتاجها المعلمون في ظل هذه النطورات الهائلة في البنية المعرفية لديهم.

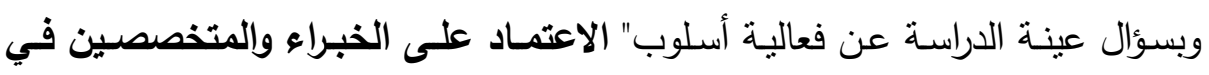

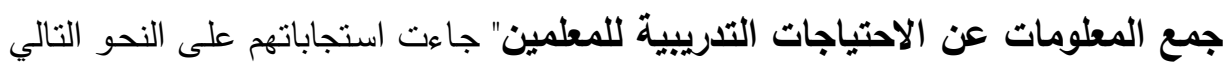

$$
\text { كما هو مبين في جدول (Yr): }
$$

فقد حظيت عبارة " تصميم برامج تدريبية تتناسب مـع الاحتياجات الفعلية للمعلمين

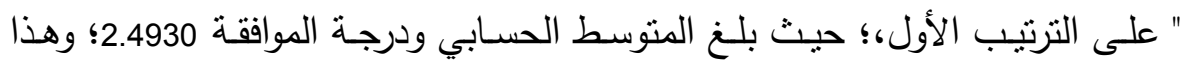

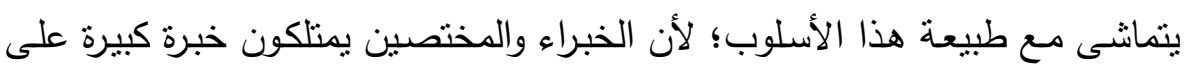

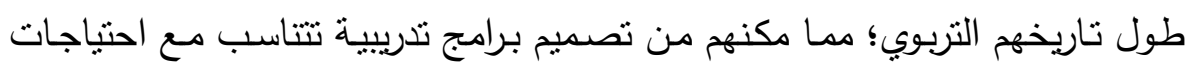

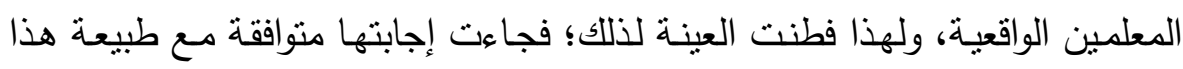

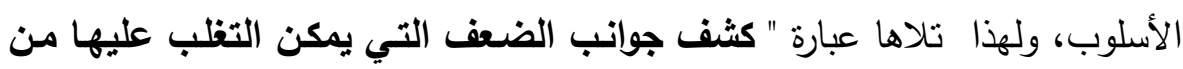

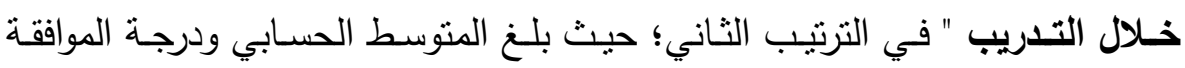

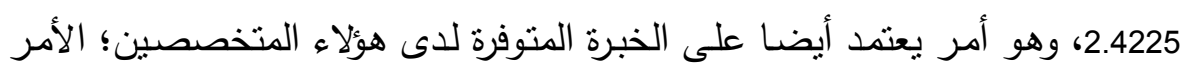

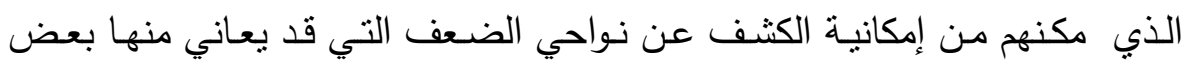
المعلمين. ثم جاءت عبارة " تخطبط برامج تلريبيـة تلبي الاحتياجـات الفعلية للمعلمين " في

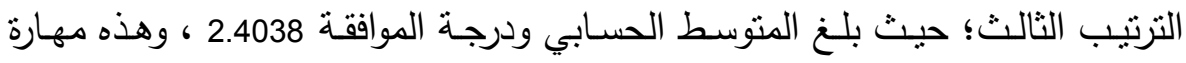
أخرى يمتلكها المتخصصون والخبراء؛ وان كانت قد جاءت في ترتيب متأخر إلى حد

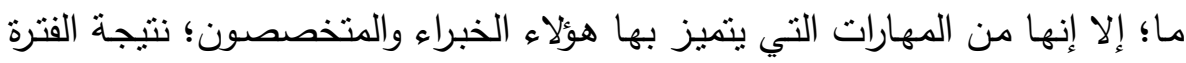

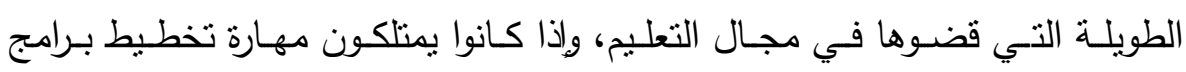

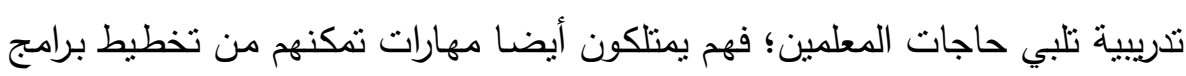

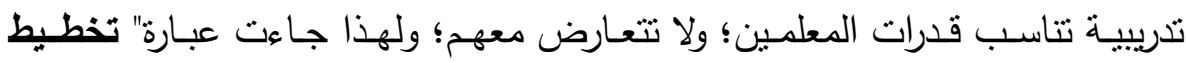
برامج تدريبية تتناسب مع قدرات المتدربين " بعدها مباثرة في الترتيب الرابع؛ حيث

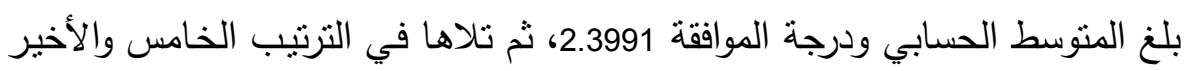

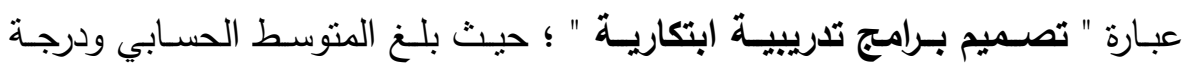
الموافقة 2.3944 ، وقد جاءت في ترتيب متأخر رغم أهمية الإبداع والابتكار في كل 
شيء، وربما يرجع السبب في ذلك إلى تعود هؤلاء الخبراء والمتخصصين على النمط

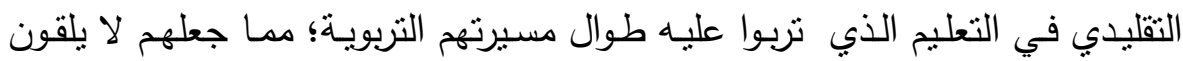

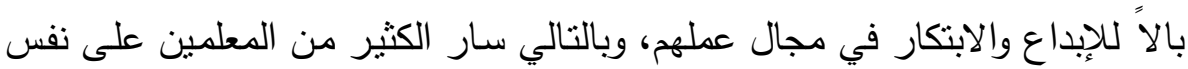
الدرب الذي سلكه سابقوهم، ولذلك لم تحظ هذه العبارة إلا بترتيب متأخر .

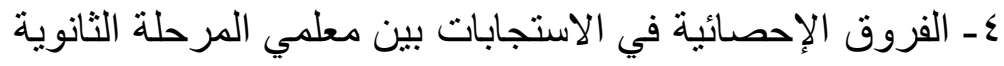

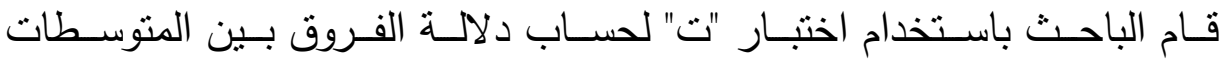

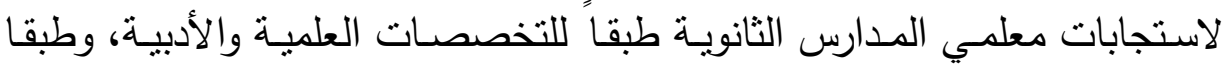
لنـوع المدرسـة( حكوميـة / أهليـة)، ويتضــح هـذا مـن خـلال استتعراض النتـائج

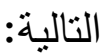

أ - الفـروق الإحصـائبة في الاسـتجابات بـين معلمـي المرحلـة الثانوبـة طبقا للتخصص ( علمي/ أدبي) حكومية / أهلية

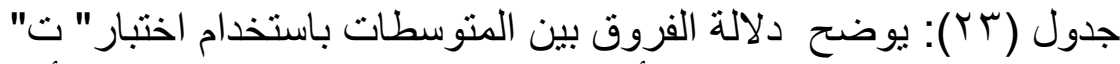

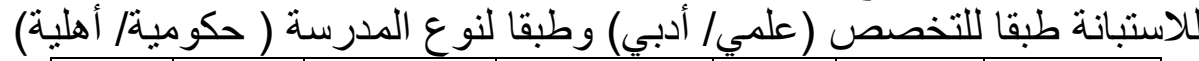

\begin{tabular}{|c|c|c|c|c|c|c|}
\hline اللالالة & قيمة ت & المعياري & المتوسط الحسابي & العد العد & المتنيرات & المتنيرات \\
\hline \multirow{2}{*}{ غالة } & \multirow[t]{2}{*}{0,683} & 10.05013 & 61.5625 & 112 & أدبي & \multirow[t]{2}{*}{ التخصص } \\
\hline & & 9.52847 & 60.6436 & 101 & علمي & \\
\hline \multirow{2}{*}{ בוי , י } & \multirow[t]{2}{*}{2.8} & 10.46188 & 59.9267 & 150 & حكومية & \multirow[t]{2}{*}{ لمدرسة } \\
\hline & & 7.29227 & 63.9841 & 63 & أهلية & \\
\hline
\end{tabular}

اتضـح من خـلال استعراض نتائج جدول (rr) عدم وجود فروق ذات دلالـة إحصـائية في الاستبانة طبقا للتخصـص (علمي/ أدبـي)، وهـذه النتيجـة تؤكد إجماع معلمي المدارس الثانوية بنين باختلاف تخصصاتهم على أهمية أساليب تحديد الاحتباجـات التدريبيـة، والاتفـاق على الصـعوبات التي تعيق استخدام أساليب تحديد الاحتياجات التدربيية للمعلمين، وكذلك التوافق على فعالية جميع أنواع أساليب تحديد الاحتياجات التدريبية.

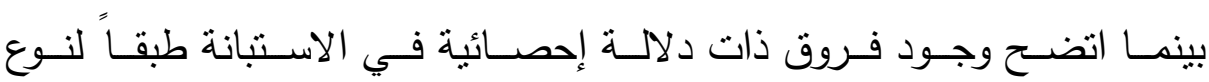

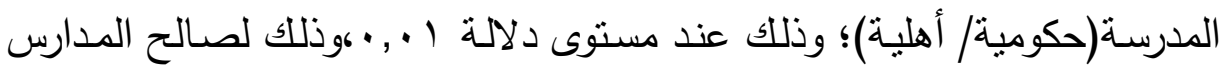


الأهليـة، وهذه نتيجـة منطقيـة؛ نظراً لاختلاف إمكانـات المـارس الحكوميـة عن

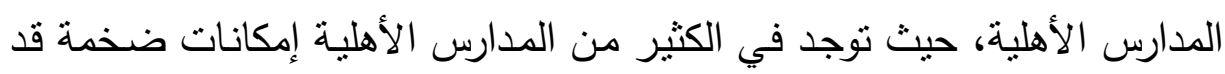
لا تتوفر للمدارس الحكوميـة، فيمكنه تشكيل لجـان مدفوعـة مثنلا تكون مهوتها الأساسية هي تحديد الاحتباجات التنريبية لمعلمي المدرسة، ومن ثم إعداد البرامج

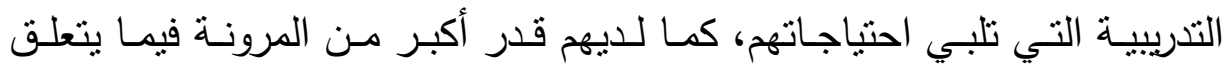

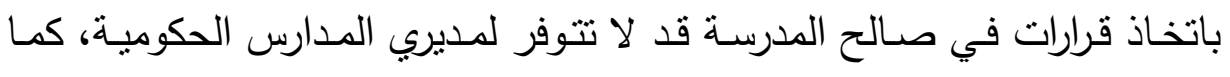
اختلفوا عن المدارس الحكومية فيما يتعلق بالصعوبات التي يمكن أن تعيق تفعيل

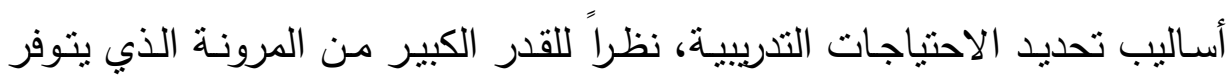

$$
\text { للمدارس الأهلية دون الحكومية. }
$$

ب- الفروق الإحصائبة في الاستجابات بـين معلمي المرحلة الثانويـة طقيَّا للمؤهل والوظيفة والخبرة

جدول (乏) بو): يوضح تحليل التباين أحادي الاتجاه لمتغيرات المؤهل والوظيفة

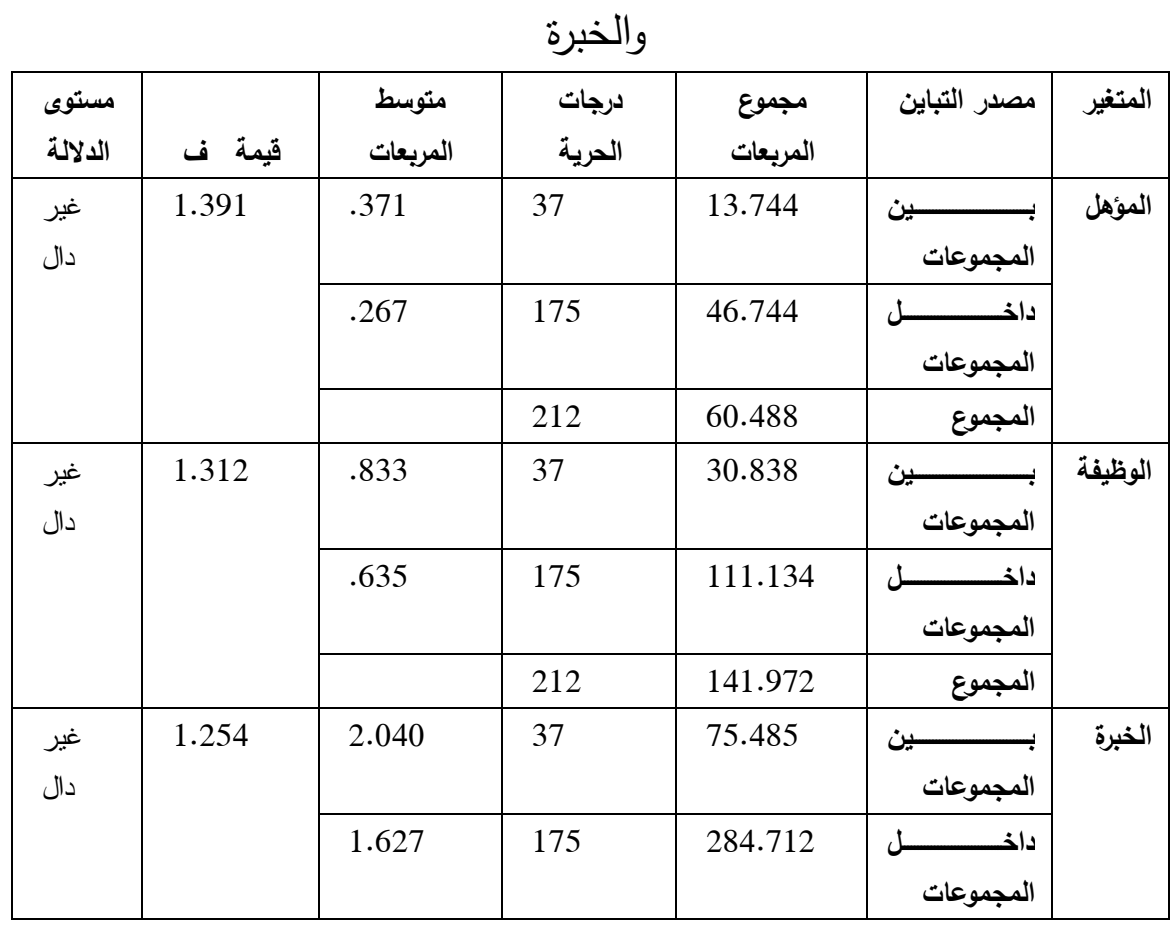




\begin{tabular}{|l|l|l|l|l|l|}
\cline { 3 - 5 } & & & \\
\hline
\end{tabular}

اتضح من الجدول (Y؟) عدم وجود فروق ذات دلالة إحصائية عند جميع محاور الاستبانة بين آراء معلمي المرحلـة الثانوبـة بمدينـة الريـاض في متغيرات المؤهل والوظيفة والخبرة، وهذا يؤكد إجماع معلمي المرحلة الثانوبـة بمدينة الرباض على أهميـة الأسـاليب المسـتخدمة في تحديـ الاحتياجـات التدربيـة، وعلى الصـعوبات التي تعيق استخدام أسـاليب تحديد الاحتياجـات التدربيـة للمعلمين، وعلى فعاليـة أسـاليب تحديد الاحتياجـات التدربيـة(المقابلات الشخصية مـع المعلمين، وأسلوب قوائم الاحتباجات التدريبية،وأسلوب الزيارات الصفية، وأسلوب الاستقصاءات التي يجربهـا مـدير المدرسـة والقيـادات الوسـطى، وأسـلوب الاعتمـاد علـى الخبـراء والمتخصصسين في جمـع المعلومـات عن الاحتياجـات التدربييـة للمعلمين)، وربمـا يرجـع السبب في ذلك إلى إدراك العينة للدور الهام لتفعيل تلك الأسـاليب، وأهمية اسـتخدامها في الارتقـاء بمهاراتهم المهنبـة؛ والتي تسـاعدهم في القيـام بـأدوارهم المختلفة في مدارسـهم؛ خاصـة وأن المعلم الآن في العصر الحسالي لـم يعد دوره قاصراً - فقط- على مجرد إلقاء الحصـة أو الدرس في الفصل؛ بل صسار مطلوبا منـه العديد من الأدوار الهامـة التي لابـد أن يؤديها:مثل: دوره في حل مشكلات إت طلابـه، ودوره كمستشـار لطلابـه، ودوره كميسر لهم وموجـه لهم كيفيـة الوصـول للمعلومـة مـن خـلال طـرق التدريس الحديثة، وغيرهـا كثيـر ، الأمـر الذي صـار يشـترك فيـه جميـع المعلمين بغض النظر عن مؤهلهم، أو وظبفتهم، أو خبرتهم التي يملكونها، وتتفق هذه النتائج مـع نتائج دراسـة" الطراونـة والطعاني ودغيمـات r . . ץ"( به)؛حيث لا توجد فروق ذات دلالة إحصائية تعزى للمؤهل أو الخبرة.

\section{تتائج الاراسة}

من خلال تفسير نتائج الدراسة ومناقشتها يمكن تحديد بعضها كالتالي: ا-إدراك معلمسي المرحلـة الثانويـة بمدينـة الريـاض لأهميـة اسـتخدام أسـاليب تحديد الاحتياجات التدريبية بأنماطها المختلفة. 
ץ-إدراك معلمـي المرحلـة الثانويـة بمدينـة الريـاض لمجموعـة مـن الصـعوبات

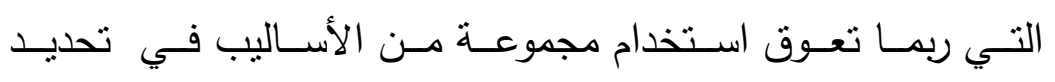

$$
\text { احتياجاتهم التدربيية. }
$$

r- عدم وجود فروق ذات دلالة إحصائية في الاستبانة بين معلمي المرحلة

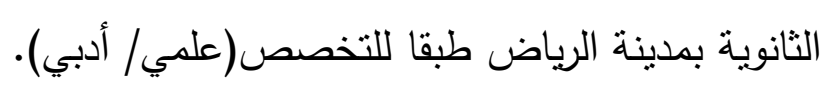

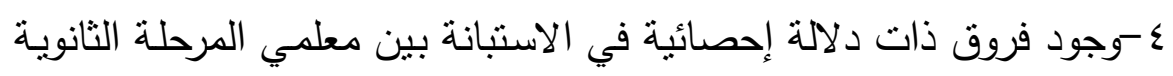

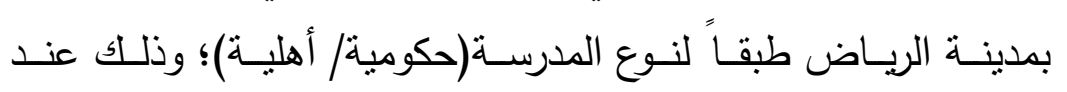
مستوى دلالة ا +., م، وذلك لصالح المدارس الأهلية.

ه-عدم وجود فروق ذات دلالة إحصائية عند جميع محاور الاستبانة بين آراء معلمي المرحلة الثانوية بمدينة الرياض في متغيرات المؤهل والوظيفة التهاته والخبرة.

تصور مقترح لتفعيل أساليب تحديد الاحتياجات التدريبية للمعلمين أولا: المنطلقات الفكرية - إن مشـاركة المعلمين مشـاركة فعليـة في تحديد احتباجـاتهم المهنيـة مـن أفضل الوسائل المساعدة على نجاح برامج التطوير المهني للمعلمين. - -

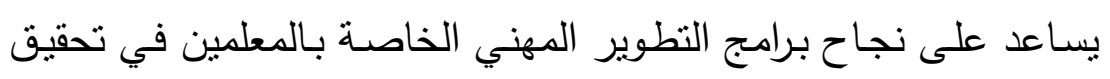
الأهداف المحددة لها. ثانيا: المنطلقات الميدانية في سبيل تفعيل أسـاليب تحديد الاحتياجـات التدريبيـة للمعلمين بمدارس التعليم

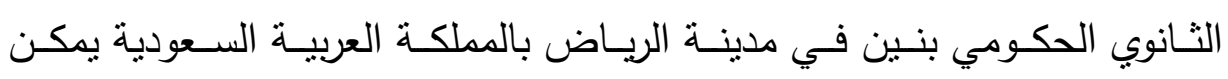
الاسترشاد بالإجراءات التالية: 1 ـ تثكيل لجنة تحديد الاحتياجات التدريبية للمعلمين أ- فلسفة عمل اللجنة 
تعد هذه اللجنة من أهم اللجان التي سيؤدي نجاحها في القيام بأعمالها إلى رفـع الكفـاءة الكليـة للمدرسـة، حيـث تثركز مهـام اللجنـة في التعـرف على الاحتياجـات الفعليـة للمعلمين، واتخاذها أساسـا لتصميم برامج تدريبيـة تسـاعد على تلبيـة هذه الاحتياجات؛ عن طربق اتبـاع الأسـاليب العلمية التي أوردتها الدراسة في إطارها النظري. وحتى تكون عمليـة تحديد الاحتياجـات التدربيـة الخاصـة بـالمعلمين شـاملة وممثلة لجميع المستوبات في المدرسة، فقد أكد "Brecher " على ضرورة أن تكون هذه اللجنة مكونة من:

$$
\text { O } 0
$$

وبحق للجنة إضافة من نراه مناسبا؛ للمساعدة على تحقيق أهدافها. (ov)

$$
\text { ب-مهام اللجنة : }
$$

يتسم العمل في هذه اللجنة بالديناميكية طوال العام الدراسي خلافا لباقي اللجان المدرسية، وعليه يمكن تحديد مهام هذه اللجنة فيما يلي:

- استبعاب الأهداف التربوية للمدرسة استبعابيا تاما وشـاملا، وادراك جميع

المدخلات التي تؤثر على تحقيق هذه الأهداف بكفاعة عالية مثل:

O اللوائح والقوانين المطبقة. o مالة المبنى المدرسي. O مدى كفايـة الميزانيـة الموضـوعة لعقد بـرامج تهدف إلى تطوير المستوى المهني للمعلمين. o المعلمون من حيث تخصصاتهم وأعدادهم وسنوات خبراتهم. 
O الطلبة من حيث أعدادهم، ومستوى تحصيلهم الدراسي.

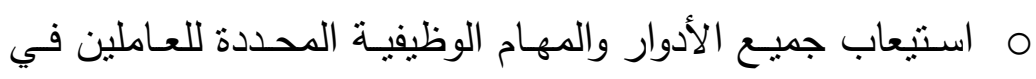
المدرسة.

- تحديـ الاحتياجـات التدريبيـة للمعلمين باتبـاع الأسـاليب العلميـة التي وردت في الدراسة الحالية. مع مراعاة الشروط التالية:

م أن يقوم بتحديد الحاجات التدريبية أثخاص متخصصون في مجالهال التدريب. م أن يتم تحديد المتدربين بصورة دقيقة. م أن براعى في تحديد الحاجات التدريبية الأساليب العلمية المعروفة. م أن يتم تحديدها بأكثر من أسلوب. م أن يتم تحديدها على مراحل زمنية متلاحقة.

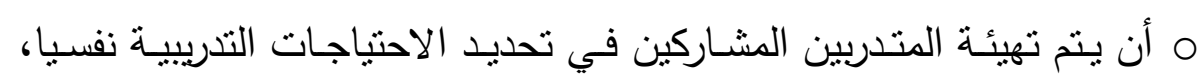
وتوعيتهم بأهمية المشاركة، ودورهم في تحديد الحاجات.

م أن يتم تحديد الحاجات للمتدربين في مناخ إيجابي يسوده التفاهم والتعاون.

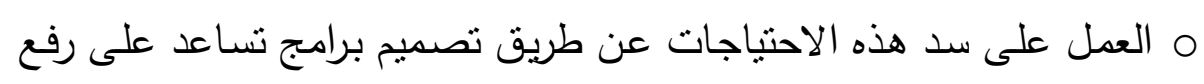

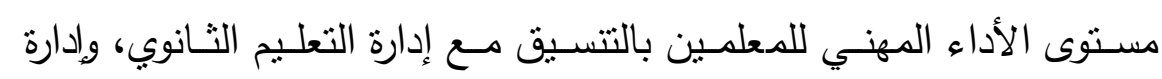
التدريب بالوزارة وكلية التربية بإحدى الجامعات السعودية في مدينة الرياض.

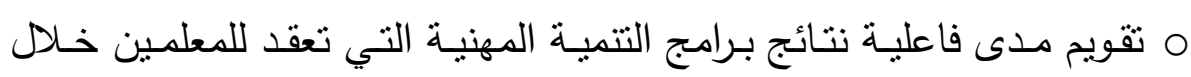
العام الدراسي. م تتبع أثر البرامج التدريبية التي تعقد للمعلمين، وتوظيف النتائج في تصميم

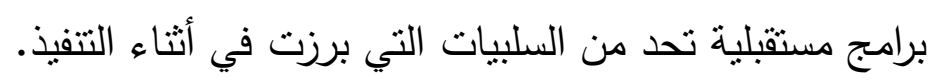

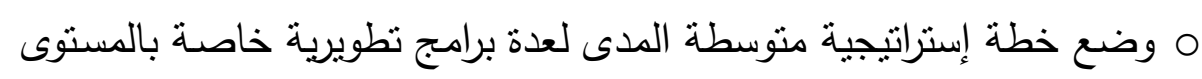
المهني للمعلمين. 
م المسـاهمة في بناء جسور التعاون بين المدرسـة وادارة التعليم الثانوي وإدارة التدريب وبين كليـة التربيـة بجامعـة الملك سـود، أو المؤسسـات المختصـة بتصميم وتتفيذ البرامج التدربيية للمعلمين. ج. الخطـوات التنفيذيـة لمهـام لجنـة تحديــ الاحتياجـات التدريبيـة الخاصـة بالمعلمبن بعد أن بـتم تشـكيل اللجنـة؛ تباشـر اجتماعاتها، وتكـون أولى هذه الاجتماعـات

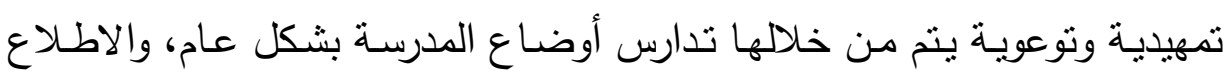

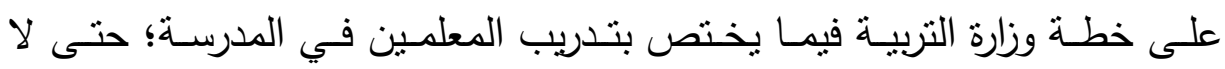
يحدث تضـارب أو ازدواجيـة بين برامج التدربب المقدمـة للمعلمين في عام واحد من قبل كل من المدرسة والوزارة. وتعـد هـذه الإجـراءات ضـرورية لعمليـة تحديـد الاحتياجـات التدربيــة الجديـدة للمعلمين؛ حيث إنها تسـاعد على دراسـة الوضـع الراهن للمدرسـة، ومعرفة مدى تـأثير هـذا الوضـع على نجـاح أو عـدم نجــاح بـرامج التتميـة المهنيـة الخاصـة بـالمعلمين التي ستتضمنها الخطة الإستراتيجية للمدرسـة، وتتمثل هذه الخطوات التنقيذية في: ثتحديـ الاحتياجـات التـريبيـة الخاصـة بـالمعلمين عن طربـق اسـتخدام عدة أساليب، حيث إن توع أساليب حصر وتحديد الاحتياجات التدريبية الخاصـة بـالمعلمين يسـاعد على نجـاح بـرامج التتميـة المهنيـة للمعلمـين في تحقيـق الأهداف المحددة لها. •ترتبب الاحتياجات التدريبية على شكل أولويات

بعد أن يتم حصر الاحتياجات التدريبية للمعلمين في جميع التخصصات عن طريت الأساليب العلمية، ويتم التعرف على حجم تلك الاحتياجات في كل تخصص، وفقا لعدد تكرار كل احتياج على حدة؛ يتم بعد ذلك

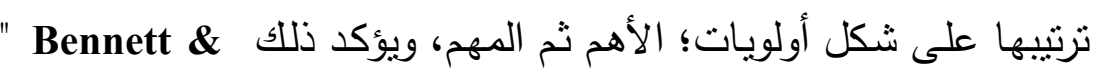


على أن تحديد الأولويات بصورة دقيقة يعد من أهم عوامل Others"

نجاح الخطط الإستراتيجية المدرسية. (0^)

ترجمـة الأولويات إلى رؤيسة ورسـالة للخطة الإستراتيجية الخاصـة ببرامج

التتمية المهنية للمعلمين بصورة مستمرة.

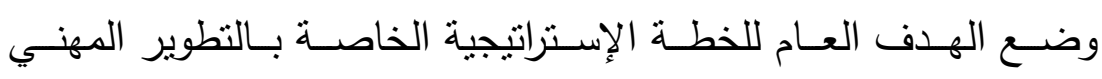

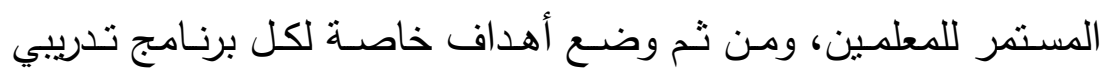

على حدة.

التعـرف على إمكانيـة تتفيـذ الأهـداف الخاصـة بـــرامج التتميـة المهنيـة

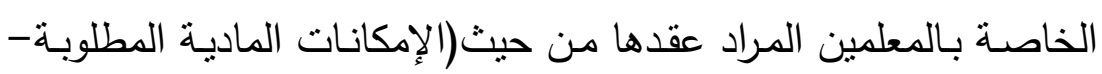

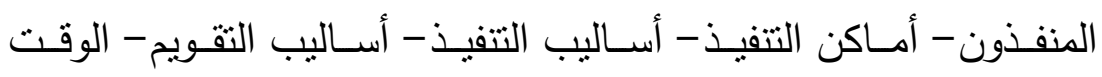

المطلوب) (ت)

تدريب القائمين على عمليـة حصـر وتحديد الاحتياجـات التدريبيـة على

استخدام وتطبيق أساليب تحديد تلك الاحتياجات . 
مجلة الدراسات التربوية والانسانية ـ كلية التربية ـ جامعة دمنهور ـ المجلد السادس - العدد الثانى - لسنة ؛ ب r 
تصور مقترح لتفعيل أساليب تحديد الاحتياجات التدريبية د. هاني محمد يونس موسى

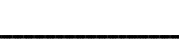




\section{المراجع}

\section{أولاً : المراجع العربية:}

ا ـ مصطفى عبدالجليل مصطفى أبو عطوان، معوقات تدريب المعلمين أثناء

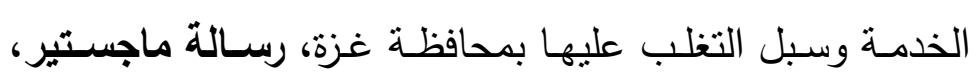

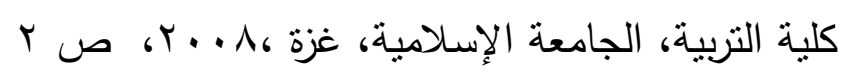

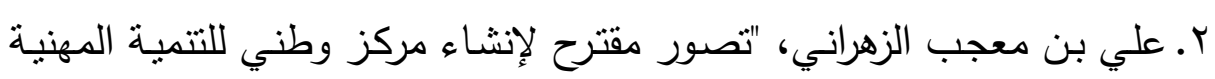

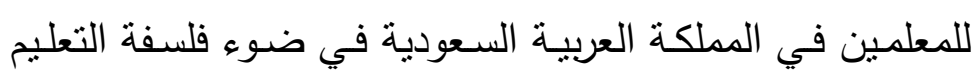

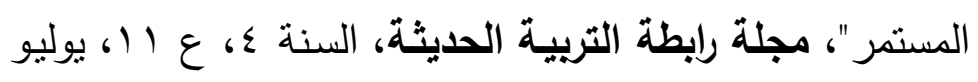

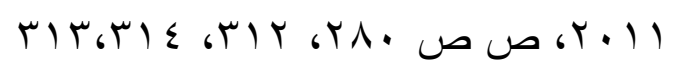

r.لمزيد من التقصيل يمكن مراجعة: وزارة المعارف، وثيقة سياسـة التعليم في صي

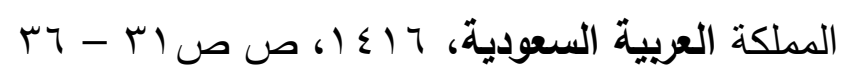

ع.وزارة الاقتصاد والتخطيط، تقرير موجز حول خطة التنمية التاسعة- المحور

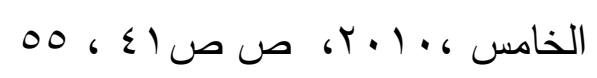

0. عبد العزيز هاشت ، نموذج تحديد الاحتياجات التدريبيـة في ظل هل المتغيرات

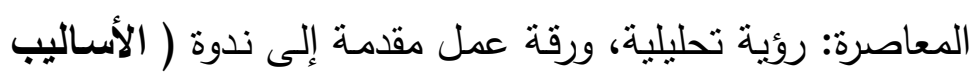

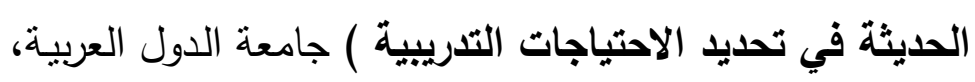

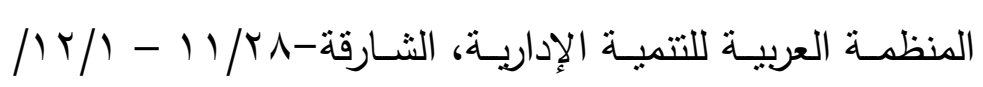

$$
\text { r. o }
$$

7 . 1 الح محمد النويجم، تقويم كفاءة العملية التدربيية في معاهد التدريب الأمنية

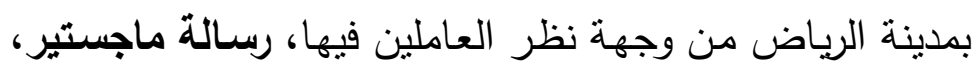

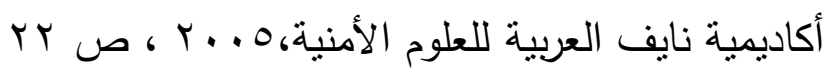

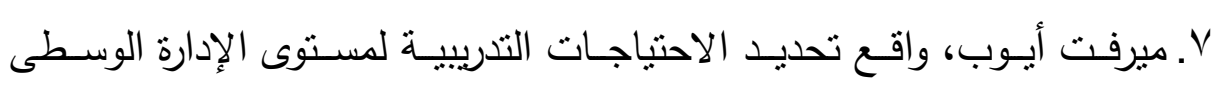

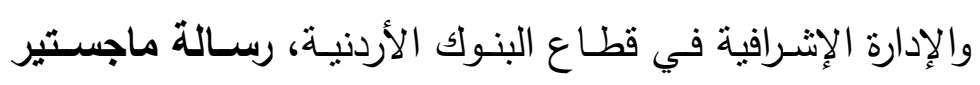

غير منشورة، الأردن، جامعة اليرموك، 1999 


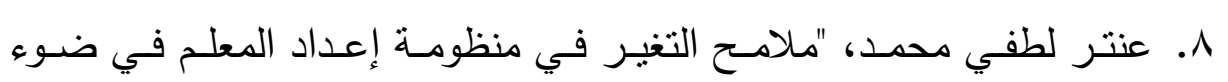

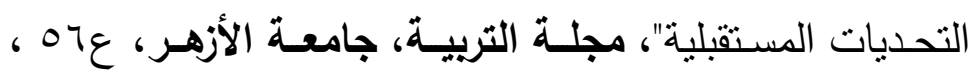

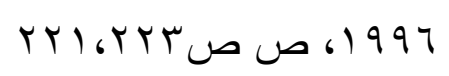

9. أوصـاف أديـب،"الاحتياجـات التدريبيـة لمعلمـي الحلقـة الأولـى مـن التعلـيم

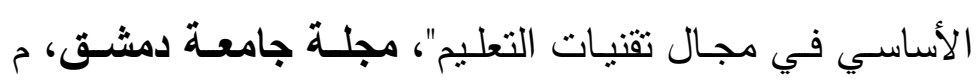

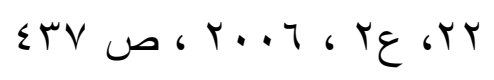

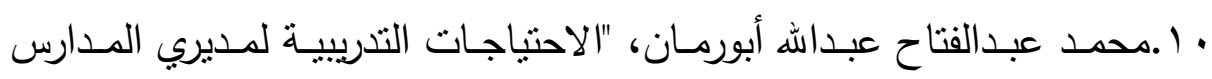

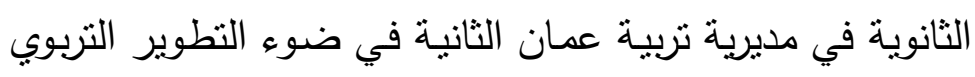

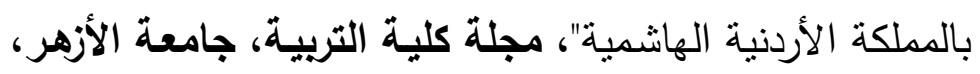

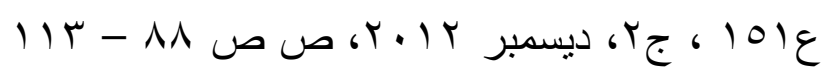

11.Trout,N.G., "A study of the perceived needs of elementary teacher in relation to grade level, educational experience, and teaching experience", Dissertation Abstracts

International,1982,VOL.44,NO.1, pp. 87- 112

r (.محد صالح خطاب، تحديد الحاجات التدريبية للمعلمين في دولة الإمارات

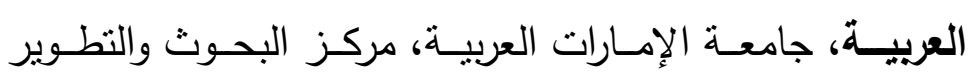

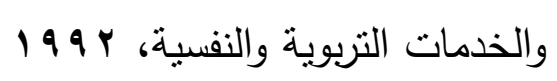

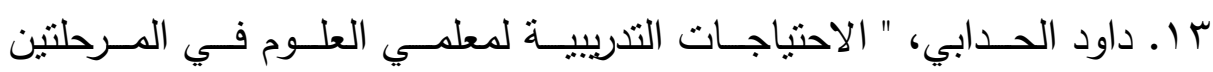

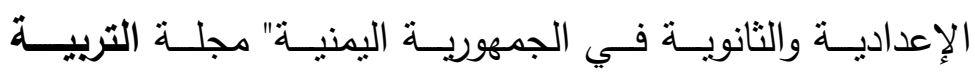

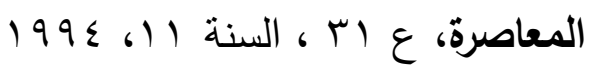

14.Seger,M. , "A study of special preparation and training needs of middle school teacher. Dissertation Abstracts International",1996,VOL.56, NO 11, pp. 106-128

10. نوال الغنيمات، الاحتياجـات التدريبيـة لمعلمي ومعلمـات المرحلة الأساسية من وجهة نظر المعلمين والمشرفين في المدارس الحكومية في

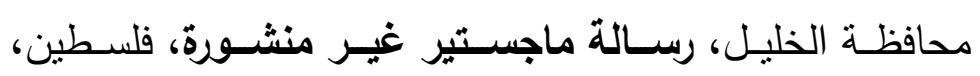

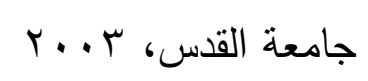

DOI: $10.12816 / 0008988$ 
7 ا .أحمد محمد هجران، دراسـة وصفية لتحديد الحاجـات التلريبية للمعلمين، مــخل لبنـاء برنـامج تـدريبي مقتـرح مسن وجهـة نظـر القـادة التريـويين والمختصسين والمشـرفين التربـويين، المملكـة العربيـة

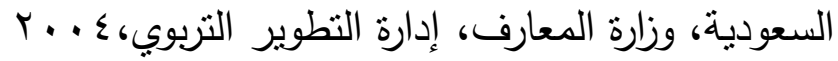
V ا. إخليـف الطراونـة وحسـن أحمـد الطعـاني وحسـين دغيمـات، "الاحتياجـات التذربييـة لمعلمي تزبيـة لـواء الأغـوار الجنوبيـة مـن وجهـة نظر المعلمين والمشـرفين التربـويين ومـديري المـدارس الحكوميـة في اللواء"، مجلة العلوم التريويـة والنفسية، جامعة البحرين، مجلد

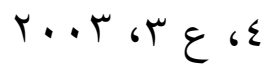

1 1 . ناجح محمد حسن محمود، الاحتياجات التدريبية للمعلمين والموجهين ورجال الإدارة المدرسية في مجال توظيف تكنولوجيا التعليم في العملية التعليميـة، بحـث مقدم إلى المـؤتمر العلمـي السـابع للجمعيـة المصرية لتكنولوجيا التعليم، بعنوان" منظومـة تكنولوجيا التعليم في المـدارس والجامعات( الواقع والمـأمول)، المنعقد في جr-

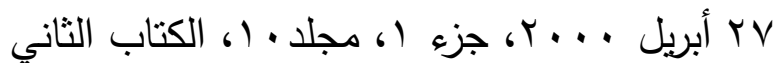
9 ا ـعبـد الـرحمن أحمـد سـيار ، "واقـع التـدريب أثتـاء الخدمـة لمعلمـي التربيـة الرياضية في مملكة البحرين، مجلة العلوم التربويـة والنفسية،

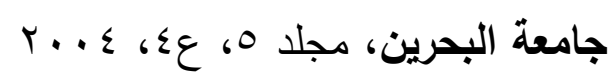

• ץ. نادية حسن السيد، "تحديد الاحتياجات التدريبية للمعمين في ضوء متطلبات مجتمــع المعرفـة" دراســة ميدانيــة"، مجلـــة مســتقبل التربيـــة

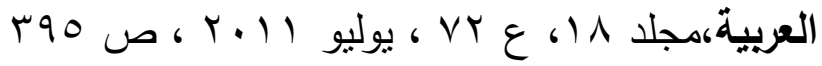
ا r.يوسـف محمد القبلان، أسسس التـديب الإداري مـع تطبيقاتهـه في المملكـة العربية السعودية، الرياض، دار عالم الكتب، ب9 9 (،صع عـ 


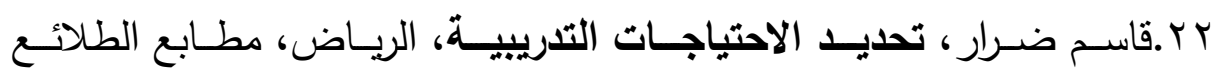

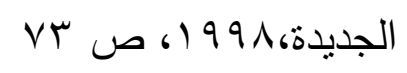

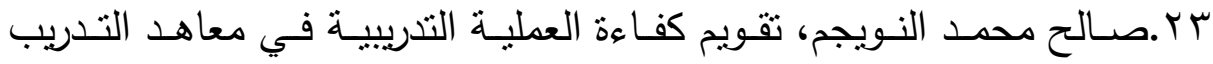

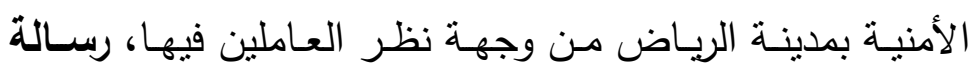

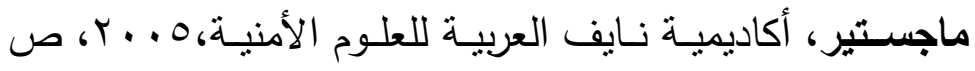
rr

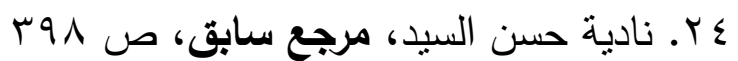

هץ ناجح محمد حسن محمود، الاحتياجات التدريبية للمعلمين والموجهين ورجال الإدارة المدرسية في مجال توظيف تكنولوجيا التعليم في العملية التعليميـة، بحث مقدم إلى المـؤتمر العلمـي السـابع للجمعيـة المصرية لتكنولوجيا التعليم، بعنوان" منظومـة تكنولوجيا التعليم

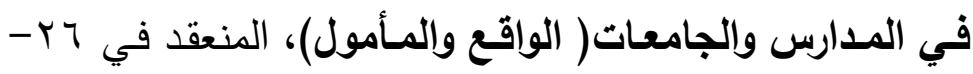

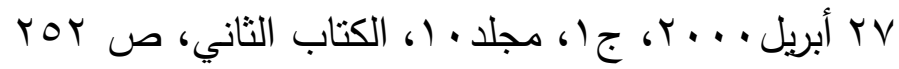

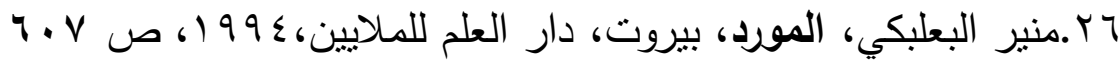

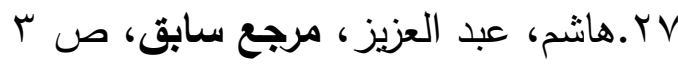

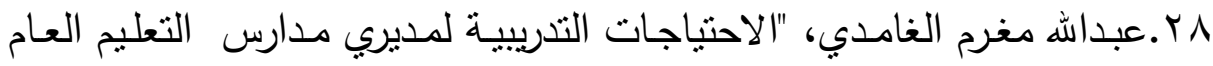

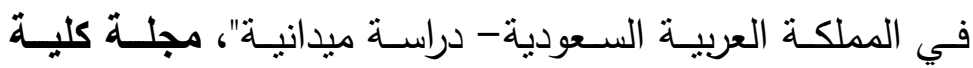

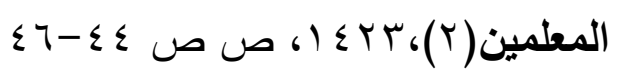

9 Y.عبد الرحمن أحمد هيجان، مفاهيم إداريـة في التدريب ، محاضرة في" دورة

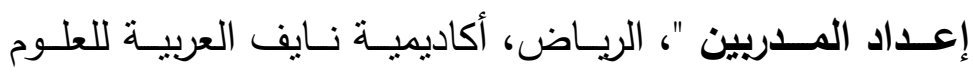

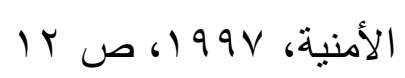

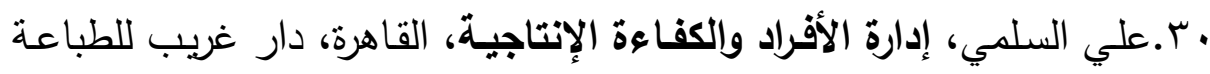

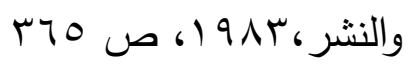


اس سمر حمد، فاعلية البرامج التدريبية لمعلمي المرحلـة الأساسية من وجهة

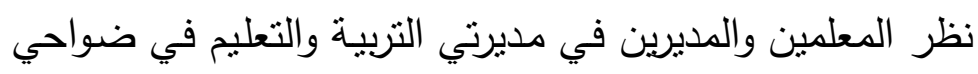

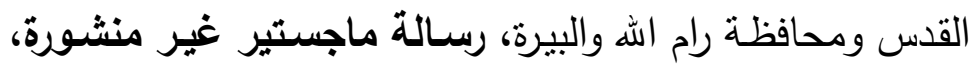

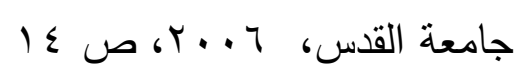

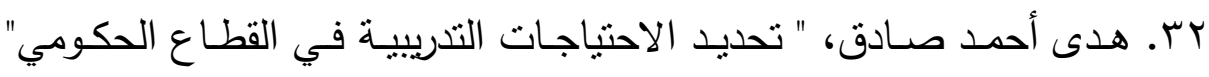

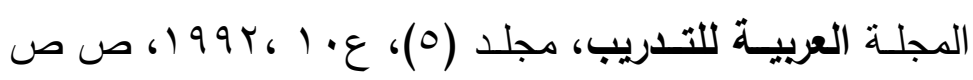

$$
\mid r-1 Y
$$

r r. حسن أحمد الطعاني، التدريب، مفهومـه، فعالياته، بناء البرامج التدريبية

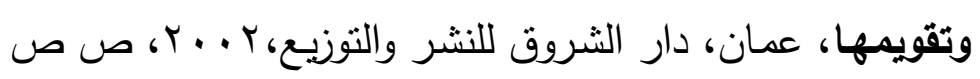

$$
\text { r-r. }
$$

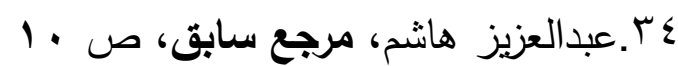

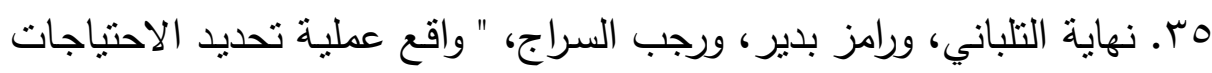

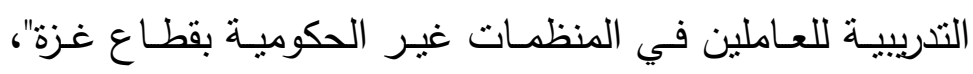

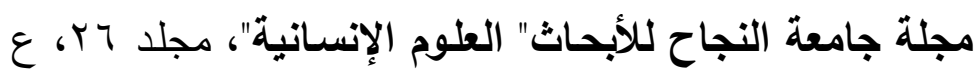

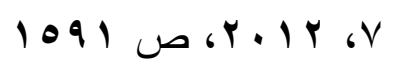

بr. سعد احمد الجبالي، تحديد الاحتياجات التدريبية، نموذج مقترح يعتمد على الهى

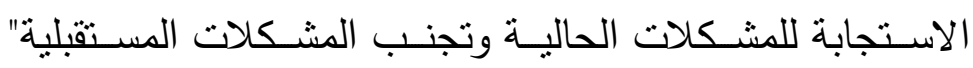

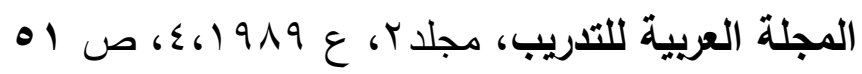

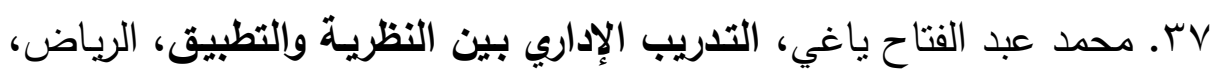

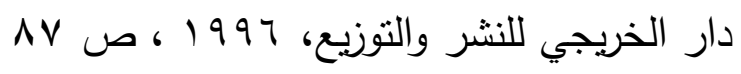

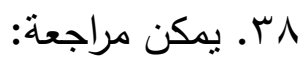
q ب.بندر بن سعد الثتري، تقويم أساليب تحديد الاحتناجات التدريبية في الأجهزة

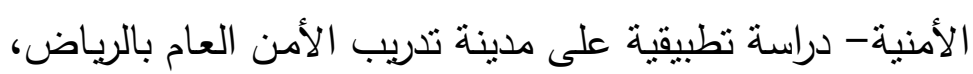


رسالة ماجستير، أكاديمية نايف العربية للعلوم الأمنية، ب . . Y،

$$
\text { V ص ص }
$$

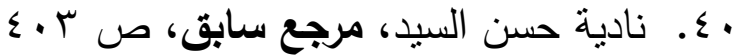

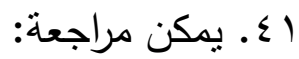

مسعود بن سعد الثتتي، البرامج التدريبية في حرس الحدود ودورها في رفع مستوى الأداء- دراسـة تقويميـة على مركز تدريب قيـادة حرس الحدود بمنطقة مكة المكرمة، رسالة ماجستير، الرياض، أكاديمية نايف العربية

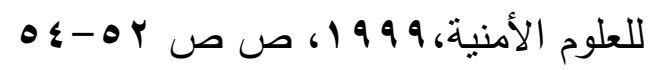

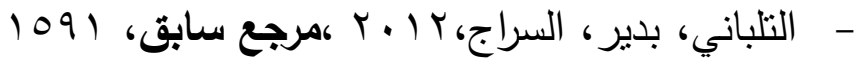

I

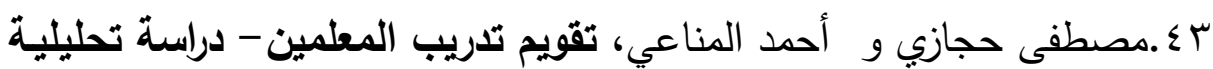

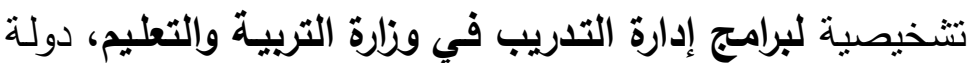

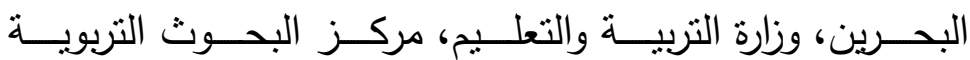

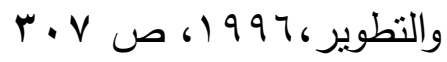

؛ ؛ .محمد عبد الفتاح ياغي، مرجع سابق، ص 19

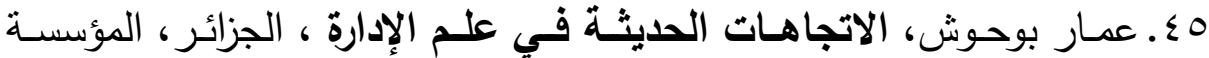

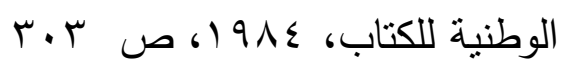

7؟ ـ عبد السلام السيد سليم، "الاحتياجات التدريبية بين الواقع والمستهدف"، مجلة

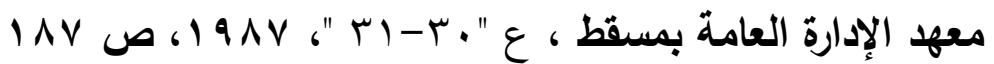
\&V

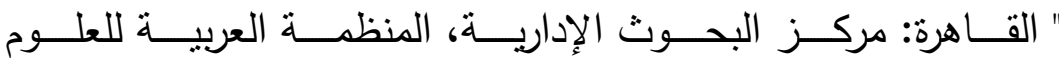

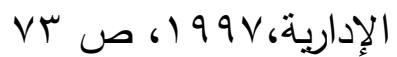


^ء ـ.زبنب علي الجبر ، القيادة التحويلية والتطوير المهني المستمر للمعلمين -

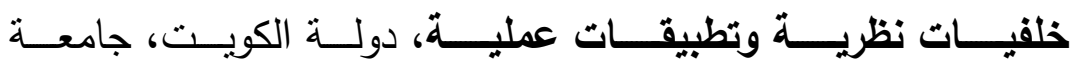

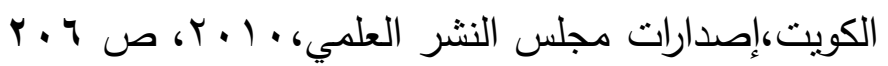
؟ ـ.لمزيد من التفاصيل يمكن مراجعة:

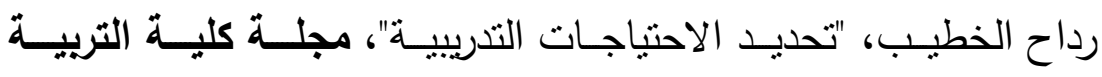

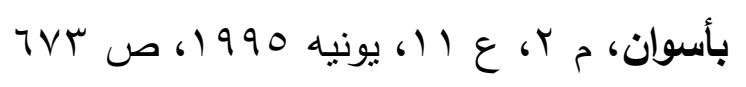

محمد عادل الأحمر، أساليب جمع المعلومات عن الاحتياجات التدريبية

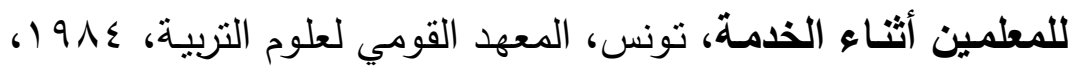

$$
\text { V ט }
$$

كابور أهـاوات وآخرون، البحث التربـوي التطبيقي، دائرة إعداد وتوجيه

المعلمين، وزارة التزبية والتعليم، مسقط، 91919 (، ص ص 199 1- . .

حنـان عبـد الحلـيم رزق، "تحديـد الاحتياجـات التدريبيـة لمعلمسي التعلـيم

الابتدائي أثتـاء الخدمـة في ضـوء كفابـاتهم المهنيـة - دراسـة مبدانيـة"،

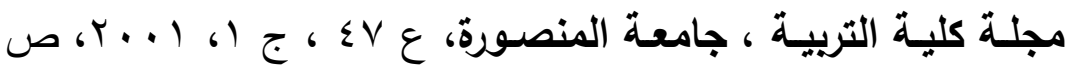

$$
\text { ص }
$$

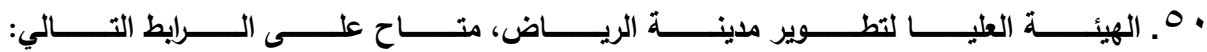
http://www.arriyadh.com/ar/AboutArriy/Left/Statistics/getdocument.a spx?f=/openshare/ar/AboutArriy/Left/Statistics/Statistics3.doc_cvt.ht

$(\underline{m}$

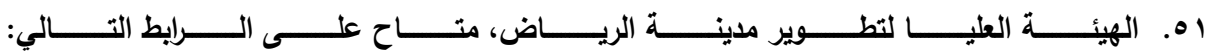
http://www.arriyadh.com/ar/AboutArriy/Left/Statistics/getdocument.a spx?f=/openshare/ar/AboutArriy/Left/Statistics/Statistics3.doc_cvt.ht

ro. محمد بن راشـد بن سـيد الحديدي، الاحتياجات التدربيـة لمديري ومديرات المدارس الإعداديـة والثانويـة بمدارس التعليم العـام في سـلطنة عمـان، 
رسالة ماجستير غير منشورة، جامعة السلطان قابوس، مسقط، عمان،

\section{1}

به. صالح أحمد أمين عبابنة، الاحتياجات التدريبية لمعلمي العلوم في المرحلة الثانوبـة في ضـوء المناهج الجديدة من وجهة نظرهم ومن وجهة نظر المشـرفين، رســالة ماجسـتير غيـر منشـور، جامعـة اليرمـوك، إربـد، الأردن،

؟ه. صـلاح ملهي السحيمي، الاحتياجات التدربيبة لمديري المدارس المتوسطة والثانوبــة الحكوميــة بمنطقـة المدينــة المنـورة فـي المملكــة العربيــة السـودية، رسـالة ماجسـتير غيـر منشـورة، جامعـة اليرمسوك ،إربـد،

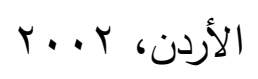

00 أحمد محمد هجران ، مرجع سابق الابق

1.07. محمد صالح خطاب ، مرجع سابق

$$
\text { oV }
$$

هـ إخليف الطراونة وحسن أحمد الطعاني وحسين دغيمات، مرجع سابق

57- Brecher, J. "A successful Model For School- Based Planning " Educational Leadership ,Sep 1992,VOL. 50,NO. 1, PP.52-54

58-Bennett,N., Crawford, M., Levacic,R., Glover,D. \& Earley, P., "The Reality of School Development Planning in the Effective Primary School: Technicist or Guiding Plan?", School Leadership and Management, 2000, VOL.20, issue 3 , p. 348 